SIMONE APARECIDA DE BESSA GARCIA

\author{
ESTUDO DA INTERAÇÃO ENTRE AS VIAS \\ DE SINALIZAÇÃO DOS ESTRÓGENOS E FATORES DE \\ CRESCIMENTO NO CONTROLE DA TRANSCRIÇÃO \\ DOS GENES HNRPK, PAWR E PHLDAI
}

Tese apresentada ao Programa de Pós-Graduação Interunidades em Biotecnologia USP/Instituto Butantan/IPT, para obtenção do Título de Doutor em Biotecnologia.

São Paulo 


\section{ESTUDO DA INTERAÇÃO ENTRE AS VIAS DE SINALIZAÇÃO DOS ESTRÓGENOS E FATORES DE CRESCIMENTO NO CONTROLE DA TRANSCRIÇÃO DOS GENES HNRPK, PAWR E PHLDAI}

Tese apresentada ao Programa de Pós-Graduação Interunidades em Biotecnologia USP/Instituto Butantan/IPT, para obtenção do Título de Doutor em Biotecnologia.

Área de concentração: Biotecnologia

Orientador: Maria Aparecida Nagai 
DADOS DE CATALOGAÇÃO NA PUBLICAÇÃO (CIP)

Serviço de Biblioteca e Informação Biomédica do

Instituto de Ciências Biomédicas da Universidade de São Paulo

(C) reprodução total

Bessa Garcia, Simone Aparecida de.

Estudo da interação entre as vias de sinalização dos estrógenos e fatores de crescimento no controle da transcrição dos genes HNRPK, PAWR e PHLDA1 / Simone Aparecida de Bessa Garcia. -- São Paulo, 2009.

Orientador: Maria Aparecida Nagai.

Tese (Doutorado) - Universidade de São Paulo. Instituto de Ciências Biomédicas. Programa de Pós-Graduação Interunidades em Biotecnologia USP/IPT/Instituto Butantan. Área de concentração: Biotecnologia. Linha de pesquisa: Genética Molecular do Câncer.

Versão do título para o inglês: Study to evaluate the crosstalk between estrogens and growth factors pathways on the transcriptional regulation of HNRPK, PAWR and PHLDA1.

Descritores: 1. Neoplasias mamárias 2. Estradiol 3. Fatores de crescimento 4. Expressão gênica 5 . Vias de sinalização intracelulares I. Nagai, Maria Aparecida II. Universidade de São Paulo. Instituto de Ciências Biomédicas. Programa de Pós-Graduação em Biotecnologia III. Título. 
UNIVERSIDADE DE SÃO PAULO

Programa de Pós-Graduação Interunidades em Biotecnologia

Universidade de São Paulo, Instituto Butantan, Instituto de Pesquisas Tecnológicas

Candidato(a): $\quad$ Simone Aparecida de Bessa Garcia.

Título da Tese: $\quad$ Estudo da interação entre as vias de sinalização dos estrógenos e fatores de crescimento no controle da transcrição dos genes HNRPK, PAWR e PHLDA1.

Orientador(a): $\quad$ Maria Aparecida Nagai.

A Comissão Julgadora dos trabalhos de Defesa da Tese de Doutorado, em sessão pública realizada a considerou

\section{( ) Aprovado(a) ( ) Reprovado(a)}

$\begin{array}{ll}\text { Examinador(a): } & \begin{array}{l}\text { Assinatura: } \\ \text { Nome: } \\ \text { Instituição: }\end{array} \\ \text { Examinador(a): } & \begin{array}{l}\text { Assinatura: } \\ \text { Nome: } \\ \text { Instituição: }\end{array} \\ \text { Essinatura: } & \begin{array}{l}\text { Nome: } \\ \text { Instituição: }\end{array} \\ \text { Assinatura: } & \begin{array}{l}\text { Nome: } \\ \text { Instituição: }\end{array} \\ & \begin{array}{l}\text { Assinatura: } \\ \text { Nome: } \\ \text { Instituição: }\end{array} \\ & \end{array}$


À Deus por iluminar minha vida e me ajudar a aceitar situações aparentemente inaceitáveis.

À memória de meus amados pais Adão e Sônia aos quais devo grande parte do que sou hoje. Ninguém morre enquanto permanece vivo no coração de alguém.

Ao meu marido Vanderlei pelo amor e companheirismo em todos os momentos. Por acreditar na minha capacidade e por lutar bravamente pela realização dos nossos sonhos.

Ao meu filhinho Vinicius que me fez compreender, desde o primeiro momento, que a vida vale a pena. Obrigada pelo sorriso espontâneo, pelo olhar carinhoso e pelo abraço sincero. 


\section{AGRADECIMENTOS}

À minha orientadora, Profa. Dra. Maria Aparecida Nagai, pela compreensão nos momentos difíceis, pelas valiosas oportunidades e pelo exemplo de profissionalismo.

Ao Prof. Dr. Giovanni Guido Cerri, chefe do Departamento de Radiologia da FMUSP, por permitir a realização deste trabalho.

À minha avó Mariana pela oração e pelo exemplo de como viver a vida intensamente.

À Sibeli pelo empenho em me ajudar a resolver os meus problemas como se fossem seus.

Aos queridos e divertidos colegas do laboratório Michelly, Daniel, Flávia, Caio, Natan, Débora, Luciana, Érika, Renê e Regina pelo companheirismo, pela ajuda e pelos momentos de descontração no dia a dia de trabalho.

Às colegas que não estão mais no laboratório, mas que também me ajudaram: Karina, Débora Casolari, Thaís e Lucimari.

À Dona Antonia pelo seu excelente trabalho na lavagem e esterilização dos materiais e por continuar nos mostrando que nenhum problema é grande o suficiente para tirar nossa alegria de viver.

À Secretaria de Biotecnologia pela atenção e auxílio durante toda a pós-graduação.

Aos funcionários da Biblioteca do Instituto de Ciências Biomédicas pela orientação para a formatação da tese.

A todos os meus amigos e a todas as pessoas que, direta ou indiretamente, colaboraram para a realização deste trabalho.

À Fundação de Amparo à Pesquisa do Estado de São Paulo (FAPESP) pela concessão da bolsa de doutorado e da reserva técnica, fundamentais para a execução deste trabalho. 
Ninguém ignora tudo, ninguém sabe tudo. Por isso, aprendemos sempre. 


\section{RESUMO}

BESSA GARCIA, S. A. Estudo da interação entre as vias de sinalização dos estrógenos e fatores de crescimento no controle da transcrição dos genes HNRPK, PAWR e PHLDA1. 120 f. Tese - Interunidades em Biotecnologia Universidade de São Paulo/Instituto Butantan/Instituto de Pesquisas Tecnológicas, São Paulo, 2009.

A interação entre as vias de sinalização dos estrógenos e dos fatores de crescimento está relacionada ao aumento da proliferação e sobrevivência das células mamárias tumorais e ao desenvolvimento da resistência aos tratamentos hormonais. Inicialmente, mostramos a ação do E2 (17ß-estradiol) no controle negativo da transcrição do PAWR (12q21), gene próapoptótico. Dados da literatura mostram que a retirada de fatores de crescimento promovem o aumento da expressão deste gene. Outro gene de interesse do laboratório é o PHLDA1 (12q15) cuja função parece estar relacionada ao processo de apoptose, sendo sua expressão induzida pelo E2 e pelo IGF-1. Baseado nestes dados, o presente trabalho teve como objetivo verificar a possível interação entre as vias de sinalização do E2 e do fator de crescimento epidermal (EGF) no controle da transcrição dos genes HNRPK, PAWR e PHLDAl utilizando as linhagens celulares de adenocarcinoma de mama MCF-7 (ER+) e MDA-MB-231 (ER-) tratadas com E2 (10nM), ICI 182,780 (ICI, antiestrógeno puro, $1 \mu \mathrm{M})$ e EGF (50ng/ml). As análises de expressão gênica e protéica foram realizadas utilizando-se as técnicas de RealTime PCR e western blot, respectivamente. Nas células MCF-7, tratamento com EGF-24h promoveu uma diminuição de 1,5 vez na expressão do $P A W R$. O tratamento com ICI por $24 \mathrm{~h}$ resultou em um aumento de 2,5 vezes na expressão deste gene $(\mathrm{p}<0,001)$. Nos tratamentos com ICI+E2 e ICI+EGF por 24h observou-se uma diminuição significativa da expressão de $P A W R$ em relação às células tratadas com o ICI-24h, porém não suficiente para retomar a expressão observada nos tratamentos com E2 ou EGF por 24h. Para o gene PHLDA1, observou-se que os tratamentos com E2-6h e EGF-2h promoveram um aumento de expressão maior que 2,0 vezes. Os tratamentos com ICI+E2 por $2 \mathrm{~h}$, $6 \mathrm{~h}$ e $24 \mathrm{~h}$ mantiveram a expressão deste gene semelhante aos tratamentos com ICI isoladamente enquanto os tratamentos com ICI+EGF por $2 \mathrm{~h}$ e $24 \mathrm{~h}$ não promoveram variação significativa da expressão do $P H L D A 1$ em relação aos respectivos tratamentos com EGF. Nas células MDA-MB-231, o EGF promoveu uma diminuição de 2,3 vezes $(\mathrm{p}<0,001)$ na expressão de $P A W R$ enquanto o aumento promovido na expressão do PHLDAl foi semelhante ao observado nas células MCF-7. O EGF promoveu a ativação do ER $\alpha$ na serina 118 via ERK1/2 para a regulação da expressão de PAWR enquanto seu efeito sobre a expressão do PHLDA1 ocorreu através da ativação das vias ERK1/2 e p38 MAPK. Em resumo, os resultados obtidos neste estudo mostram que o E2 e o EGF controlam negativamente a expressão do PAWR e positivamente a expressão do PHLDA1. Em adição, existe interação entre as vias de sinalização do E2 e do EGF para o controle da transcrição do PAWR enquanto o efeito do EGF sobre a expressão de PHLDA1 é independente do ER e mediado pelas vias ERK1/2 e p38 MAPK.

Palavras-chave: Neoplasias mamárias. Estradiol. Fatores de crescimento. Expressão gênica. Vias de sinalização intracelulares. 


\begin{abstract}
BESSA GARCIA, S. A. Study to evaluate the crosstalk between estrogens and growth factors pathways on the transcriptional regulation of HNRPK, PAWR and PHLDA1. 120 p. Thesis - Interunidades em Biotecnologia Universidade de São Paulo/Instituto Butantan/Instituto de Pesquisas Tecnológicas, São Paulo, 2009.
\end{abstract}

Crosstalk between the estrogens and growth factors signaling pathways has been associated with proliferation and survival of the breast tumor cells and with the development of resistance to endocrine therapies. Previously, we have shown the effects of E2 (17 $\beta$-estradiol) on the negative control of the pro-apoptotic gene PAWR (PRKC apoptosis WT1 regulator protein; also known as PAR-4), in the MCF-7 breast cancer cells. Data from our group and others also have shown that growth factors withdrawal increases PAWR gene expression. We also have previously demonstrated that the transcripts of another gene, the PHLDA1 (pleckstrin homology-like domain, family A, member 1), whose function might be related to apoptosis, is up-regulated by E2 and the growth factor IGF-1. In the present study, we sought to determine the possible crosstalk between E2 and epidermal growth factor (EGF) signaling pathways on the HNRPK, PAWR and PHLDAl expression regulation in MCF-7 (ER+) breast cancer cells. To accomplish that, MCF-7 cells were treated with E2 (10nM), ICI 182,780 (ICI, a pure antiestrogen, $1 \mu \mathrm{M})$ e EGF $(50 \mathrm{ng} / \mathrm{ml})$. mRNA and protein expression were evaluated by Real Time PCR and western blot, respectively. MCF-7 cells esposed to EGF for $24 \mathrm{~h}$ showed 1,5-fold decrease on the PAWR mRNA expression. Treatment with ICI for $24 \mathrm{~h}$ resulted in a 2,5-fold increase on gene expression ( $\mathrm{p}<0,001)$. When MCF-7 cells were treated with a combination of ICI+E2 and ICI+EGF for $24 \mathrm{~h}$ we observed a significative decrease on PAWR mRNA expression in relation to cells treated with ICI alone for $24 \mathrm{~h}$, although this decreased did not reach the levels displayed by te cells treated with E2 or EGF for $24 \mathrm{~h}$. For the PHLDA, treatment of MCF-7 cells with the E2 for $6 \mathrm{~h}$ and EGF for $2 \mathrm{~h}$ resulted in increased its expression more than 2-fold. The ICI+E2 treatment for $2 \mathrm{~h}, 6 \mathrm{~h}$ and $24 \mathrm{~h}$ kept PHLDA1 mRNA expression similar to ICI treatments alone while the ICI+EGF treatment for $2 \mathrm{~h}$ e $24 \mathrm{~h}$ did not change PHLDAl expression when compared to the respective EGF treatment. In MDA-MB-231 cells (ER- and EGFR+), the EGF promoted a 2,3-fold decrease $(\mathrm{p}<0,001)$ on the $P A W R$ expression while the fold change on the PHLDAl increased expression was similar to that observed on MCF-7 cells. The EGF promoted the ER $\alpha$ activation on serine 118 via ERK1/2 to the $P A W R$ expression control while its effect over the PHLDA1 expression was conducted by ERK1/2 and p38 MAPK activation. In conclusion, these findings show that E2 and EGF negatively regulate the PAWR expression and positively regulate the PHLDA1 expression. In addition, there is a crosstalk between E2 and EGF signaling pathways on the $P A W R$ transcriptional regulation while the effects of EGF on PHLDA1 expression is ER-independent and mediated by ERK1/2 and p38 MAPK pathways.

Key words: Mammary neoplasms. Estradiol. Growth factors. Gene expression. Intracellular pathways. 


\section{LISTA DE ILUSTRAÇÕES}

Figura 1. Processo de evolução clonal.............................................................. 28

Figura 2. Alterações genéticas e progressão do câncer de mama.............................. 29

Figura 3. Representação esquemática do receptor de estrógeno humano alfa e do receptor de estrógeno humano beta.

Figura 4. Representação esquemática dos domínios estruturais e funcionais do ER.

Figura 5. Mecanismos de ativação da transcrição pelo ER

Figura 6. Integração da sinalização genômica e não genômica/rápida do ER (receptor de estrógeno) e sua interação com o receptor de fator de crescimento e as vias celulares mediadas por quinases na resistência endócrina.

Figura 7. Base estrutural para a dimerização e ativação dos receptores ERBB....... 43

Figura 8. A via de sinalização ERBB................................................................... 44

Figura 9. Mapa do vetor pU6+27 representando os diversos sítios de restrição nele presentes e suas respectivas posições

Figura 10. Análise da qualidade e integridade do RNA extraído das células MCF7 pela técnica guanidina fenol-clorofórmio

Figura 11. Amplificação dos genes $G A P D H$ (A) e $\beta$-2-microglobulina (B) para análise da qualidade e da homogeneidade da massa dos cDNAs sintetizados.

Figura 12. Efeito das diferentes condições de cultura na expressão relativa do gene PAWR nas células MCF-7.

Figura 13. Efeito das diferentes concentrações de EGF (fator de crescimento epidermal) na expressão relativa dos genes HNRPK e PAWR nas células MCF-7.

Figura 14. Efeito do EGF (fator de crescimento epidermal) na expressão relativa dos genes HNRPK (A) e PAWR (B) nas células MCF-7.

Figura 15. Efeito do EGF (fator de crescimento epidermal), E2 (17ß-estradiol) e TAM (tamoxifen) na expressão relativa do gene HNRPK nas células MCF-7

Figura 16. Efeito do E2 (17ß-estradiol) e do ICI (ICI 182,780) na expressão relativa do gene $P A W R$ nas células MCF-7.

Figura 17. Efeito do E2 (17ß-estradiol) e do ICI (ICI 182,780) na expressão relativa do gene $P H L D A 1$ nas células MCF-7.

Figura 18. Efeito do EGF (fator de crescimento epidermal) e do ICI (ICI 182,780) na expressão relativa do gene $P A W R$ nas células MCF-7.

Figura 19. Efeito do EGF (fator de crescimento epidermal) e do ICI (ICI 182,780) na expressão relativa do gene $P H L D A 1$ nas células MCF-7.

Figura 20. Efeito do E2 (17ß-estradiol), EGF (fator de crescimento epidermal), ICI (ICI 182,780), LY (LY 294002) E SB (SB 202190) na expressão relativa do gene $P A W R$ nas células MCF-7.

Figura 21. Efeito do EGF (fator de crescimento epidermal), LY (LY 294002), SB (SB 202190) e PD (PD 98059) na expressão relativa do gene $P A W R$ nas células MCF-7. 
Figura 22. Efeito do EGF (fator de crescimento epidermal), LY (LY 294002), SB (SB 202190) e PD (PD 98059) na expressão relativa do gene PHLDAI nas células MCF-7.

Figura 23. Efeito do E2 (17ß-estradiol), ICI (ICI 182,780), EGF (fator de crescimento epidermal) e PD (PD98059) na expressão relativa do gene (RNAm) e da proteína PHLDA1 nas células MCF-7...

Figura 24. Efeito do E2 (17ß-estradiol), ICI (ICI 182,780), EGF (fator de crescimento epidermal) e PD (PD98059) na expressão das proteínas PHLDA1, p-ERK e p-p38 MAPK nas células MCF-7.

Figura 25. Efeito do E2 (17ß-estradiol), ICI (ICI 182,780), EGF (fator de crescimento epidermal) e PD (PD98059) na expressão da proteína pER (S118) nas células MCF-7.

Figura 26. Expressão do gene $E R \alpha(A)$ e da proteína $E R \alpha(B)$ após a supressão da expressão do referido gene utilizando o siRNA transiente nas células MCF-7.

Figura 27. Expressão dos genes $P A W R$ e $P H L D A 1$ após supressão da expressão do ERa utilizando o siRNA transiente nas células MCF-

Figura 28. Efeito do EGF (fator de crescimento epidermal) e do ICI (ICI 182,780) na expressão relativa do gene $P A W R$ nas células MDA-MB-231.

Figura 29. Efeito do EGF (fator de crescimento epidermal) e do ICI (ICI 182,780) na expressão relativa do gene $P H L D A 1$ nas células MDA-MB-231.. 


\section{LISTA DE TABELAS}

Tabela 1. Diluições dos anticorpos primários e secundários utilizados, tamanho das proteínas analisadas e concentração do gel de separação. 


\section{LISTA DE ABREVIATURAS E SIGLAS}

$\Delta$ - delta

$\mu \mathrm{g}$ - micrograma

$\mu \mathrm{l}$ - microlitro

$\mu \mathrm{m}$ - micrometro

$\mu \mathrm{M}$ - micromolar

${ }^{\circ} \mathrm{C}$ - graus Celsius

17-ßHSD - hidroxiesteróide (17-beta) desidrogenase 1 (Hydroxysteroid (17-beta)

Dehydrogenase 1)

3D - 3 dimensões

A- adenina

aa- aminoácido

Abl - v-abl Abelson oncogene viral de leucemia murina

ACTB - actina beta

AF-1 - função de ativação 1 (Activation Function 1)

AF-2 - função de ativação 2 (Activation Function 2)

AF-2a - função de ativação 2 (Activation Function 2) a

AF-2b - função de ativação 2 (Activation Function 2) b

AIB1 - amplificado no câncer de mama 1 (Amplified in Breast Cancer 1)

Akt- homólogo ao oncogene viral v-akt de thimona murino

Amp- amplificação

AP-1 - proteína de ativação 1 (Activation Protein 1)

APS- persulfato de amônia (amonium persulfate)

ATCC - American Type Culture Collection

ATF-2 - fator de ativação da transcrição 2 (Activation Transcription Factor 2)

ATM - mutado na ataxia telangiectasia (Ataxia Telangiectasia Mutated)

ATRS - Sequência de resposta rica em AT (AT-rich Response Sequence)

Bad - agonista de morte celular associado à BCL2 (BCL2-associated agonist of cell death)

BCL2 - célula-B CLL/linfoma 2 (B-cell CLL/Lymphoma 2)

BCL-xL - semelhante ao BCL-2 tipo 1 (BCL2-like 1)

bp - pares de base

BRCA 1 - câncer de mama 1 (Breast Cancer 1) 
BRCA 2 - câncer de mama 2 (Breast Cancer 2)

BSA - Albumina bovina sérica (Bovine Serum Albumin)

C- Citosina

$\mathrm{Ca}^{++}$ou $\mathrm{Ca}^{2+}$ - Cátion Cálcio

CaMK - proteína quinase II dependente de cálcio e calmodulina (calcium/calmodulindependent protein kinase II)

cAMP - 3', 5' monofosfato cíclico de adenosina (cyclic adenosine monophosphate)

Cav - caveolina

$\mathrm{Cbl}$ - sequência transformante ecotrópica retroviral Cas-Br-M (murina) (Cas-Br-M [murine] ecotropic retroviral transforming sequence)

CBP - proteína de ligação ao CREB [CREB: proteína de ligação ao elemento responsivo ao AMP-cíclico] (CREB [CREB: cyclic-AMP responsive element binding protein]-Binding Protein)

CCNA - ciclina A

CCND1 - ciclina D1

cDNA - ácido desoxirribonucléico complementar (Complementary Deoxyribonucleic Acid) $\mathrm{cm}$ - centímetro

c-myc - homólogo ao oncogene viral v-myc de mielocitomatose (aviário)

CoA - Co-ativador

CRH- hormônio liberador de corticotropina (Corticotropin Releasing Hormone)

Crk - homólogo ao oncogene v-crk sarcoma vírus CT10 (aviário)

$\mathrm{c}-\mathrm{Src}$ - vide src

CT - Threshold Cycle

CYP1A1 - citocromo P450, família 1, subfamília A, polipeptídeo 1

Cyr61 - rico em cisteína, indutor angiogênico 61 (cysteine-rich, angiogenic inducer, 61)

Da - Dalton

DAX-1 - receptor nuclear subfamília 0 , grupo $\mathrm{B}$, membro 1

DBD - domínio de ligação ao DNA (DNA Binding Domain)

DMSO - dimetil sulfóxido

DNA - ácido desoxirribonucléico (Deoxyribonucleic Acid)

dNTPs - 2' desoxirribonucleotídeos 5' trifosfato (2' Deoxynucleotides 5' Triphosphate)

DTT - dithiothreitol

E2- $17 \beta$-estradiol

EDTA - ácido etileno diamino teraacético (Ethylenediaminetetracetic Acid) 
EGF- fator de crescimento epidermal (Epidermal Growth Factor)

EGFR - receptor do fator de crescimento epidermal (Epidermal Growth Factor Receptor)

Egr1 - resposta precoce ao crescimento 1 (early growth response 1)

EGTA - Etileno glicol - bis - (beta-Amino - Etileter) - N, N, N', N' - ácido tetraacético

(Ethylene Glycol - bis - (beta - Amino - Ethylether) - N, N, N', N'-tetraacetic acid)

Elk - receptor B1 do EPH (EPH receptor B1)

ER - receptor de estrógeno (Estrogen Receptor)

ER- -receptor de estrógeno (Estrogen Receptor) negativo

$\mathrm{ER} \alpha$ - receptor de estrógeno (Estrogen Receptor) alfa

ER $\beta$ - receptor de estrógeno (Estrogen Receptor) beta

ER+- receptor de estrógeno (Estrogen Receptor) positivo

ERBB1 - homólogo ao oncogene viral (v-erb-b) de leucemina eritroblástica (aviária)

ERBB2 - homólogo 2 ao oncogene viral (v-erb-b2) de leucemina eritroblástica, oncogene

homólogo derivado de neuro/glioblastoma (aviária)

ERBB3- homólogo 3 ao oncogene viral (v-erb-b2) de leucemina eritroblástica (aviária)

ERBB4 - homólogo 4 ao oncogene viral (v-erb-a) de leucemina eritroblástica (aviária)

ERE - elemento responsivo ao estrógeno (Estrogen Responsive Element)

ERK - quinase regulada por sinais extracelulares (extracellular signal-regulated kinase)

ESR1- receptor de estrógeno 1 (Estrogen Receptor 1)

ESR2- receptor de estrógeno 2 (Estrogen Receptor 2)

ET - endotelina

FADD - domínio de morte associado à via Fas (Fas-associated via death domain)

Fas - membro 6 da superfamília de receptores do fator de necrose tumoral

Fase $\mathrm{G}$ - fase Gap do ciclo celular

Fase $\mathrm{S}$ - fase de Síntese do ciclo celular

FGF - fator de crescimento de fibroblastos (Fibroblast Growth Factor)

FGFR - Receptor do fator de crescimento de fibroblastos (Fibroblast Growth Factor Receptor)

Fos - homólogo ao oncogene viral (v-fos FBJ) de osteosarcoma murino

Fyn - proteína tirosina quinase pertencente à família Src

g - grama

G- guanina

GAP - proteína ativadora de GTPase (GTPase-activating protein) 
GAPDH - gliceraldeído 3-fosfato desidrogenase (Glyceraldehyde-3-Phosphate Dehydrogenase)

GDP - guanosina difostato (guanosine diphosphate)

GF - Fator de crescimento (Growth Factor)

GP - Proteína G ( $G$ protein)

GPCR - Receptor acoplado a proteínas G (G Protein Coupled Receptor)

Grb2 - proteína 2 ligada ao receptor de fator de crescimento (growth factor receptor-bound protein 2). Proteína adaptadora

Grb7 - proteína 7 ligada ao receptor de fator de crescimento (growth factor receptor-bound protein 7). Proteína adaptadora

GSK - quinase glicogêncio sintase 3 (Glycogen Synthase Kinase)

GSTM1 - Glutationa S-Transferase M1

GTP - guanosina trifostato (guanosine triphosphate)

h- hora

HB-EGF- fator de crescimento semelhante ao EGF ligado à heparina (Heparin-binding EGFlike growth factor)

hnRNPs- ribonucleoproteínas heterogêneas nucleares (Heterogeneous Nuclear Ribonucleoproteins)

HNRPK- ribonucleoproteína heterogênea humana $\mathrm{K}$ (Heterogeneous Nuclear Ribonucleoprotein $K$ )

HPRT1- hipoxantina fosforibosil transferase 1 (hypoxanthine phosphoribosyltransferase 1) $\mathrm{H}$ - Ras - homólogo ao oncogene viral v-Ha-ras de sarcoma de rato (v-Ha-ras Harvey rat sarcoma viral oncogene homolog)

Hsp - proteína de choque térmico (Heat Shock Protein)

ICI - Imperial Chemical Industries

IGF-1 - fator de crescimento semelhante à insulina 1 (Insulin-like Growth Factor 1)

IGF-1R - Receptor do fator de crescimento semelhante à insulina 1 (Insulin-like Growth Factor Recptor 1)

IGF-BP4 - proteína de ligação ao fator de crescimento semelhante à insulina 4 (Insulin-like Growth Factor Binding Protein 4)

IGFR - receptor do fator de crescimento semelhante à insulina (Insulin-like Growth Factor Receptor)

IL12 - cadeia 12 alfa da interleucina (interleukin-12 $\alpha$ chain)

INCA - Instituto Nacional do Câncer 
iNOS - óxido nítrico sintetase induzida (inducible nitric oxide synthase)

Jak - kinase janus (Janus Kinase)

JNK - proteína quinase 8 ativada pelo mitógeno

JNKK - proteína quinase quinase 4 ativada pelo mitógeno

Jun - oncogene homólogo ao v-jun sarcoma vírus 17

$\mathrm{kb}$ - quilo base

$\mathrm{kDa}$ - quilo Dalton

K- Ras - homólogo ao oncogene viral v-Ki-ras2 de sarcoma de rato (v-Ki-ras2 Kirsten rat sarcoma viral oncogene homolog)

1 - litro

LB - Luria-Bertani (meio de cultura de bactérias)

LBD - domínio de ligação ao ligante (Ligand Binding Domain)

LOH - perda de heterozigose (Loss of Heterozigosity)

LPA - ácido lisofosfatídico (lysophosphatidic acid)

LY 294002 - 2-(4-Morfolinil)-8 fenil-4 H-1-benzopirano-4-um (2-[4-Morpholinyl]-8phenyl-4 H-1-benzopyran-4-one)

Lyn - homólogo relacionado ao oncogene viral v-yes-1 Yamaguchi de sarcomahomólogo relacionado ao sarcoma viral. Proteína tirosina quinase pertencente à família Src

M - molar

MAPK - proteína quinase ativada pelo mitógeno (mitogen-activated protein kinase)

MAPKK - proteína quinase quinase ativada pelo mitógeno (mitogen-activated protein kinase kinase)

MEK - quinase ativada pelo mitógeno

MEM - meio mínimo essencial (Minimal Essential Medium)

$\mathrm{mg}$ - miligrama

MISS - Sinalização esteroídica iniciada na membrana (Membrane-Initiated Steroid Signaling)

$\mathrm{ml}$ - mililitro

$\mathrm{mM}$ - milimolar

MMP- metalopeptidase de matriz (Matrix Metallopeptidase)

MNAR - modulador da atividade não-genômica do receptor de estrógeno (Modulator of Nongenomic Activity of Estrogen Receptor)

MnSOD - manganês superóxido dismutase (Manganese Superoxide Dismutase)

MOPS - ácido propanesulfônico 3-[N-morfolino] (3-[N-Morpholino] Propanelsufonic Acid)

MTA1 - associado a metástase 1 (metastasis associated 1) 
Mut- mutação

MYC - vide c-myc

$\mathrm{N}$ - qualquer ácido nucléico (A, C, G ou T)

NAT1 - N-acetiltransferase 1

NAT2 - N-acetiltransferase 2

Nck - proteína adaptadora Nck

N-COR - co-repressor do receptor nuclear (Nuclear Receptor Co-Repressor)

NF- $\mathrm{BB}$ - fator nuclear do gene enhancer do polipeptídio leve Kappa nas células-B 1 (Nuclear

Factor of Kappa Light Polypeptide Gene Enhancer in B-cells 1)

ng- nanograma

NGF - fator de crescimento de nervos (Nerve Growth Factor)

NGFR - receptor do fator de crescimento de nervos (Nerve Growth Factor Receptor)

nm- nanômetro

NME1 - células não metastáticas 1 (non-metastatic cells 1)

NRG 1, 2, 3 e 4- neuregulina 1, 2, 3 e 4

p- braço curto de um cromossomo

P- fosforilação

p/CAF - fator associado ao p300/CBP (p300/CBP-Associated Factor)

P160 - proteína de ligação ao MYB (oncogene homólogo a mieloblastose viral v-myb)

p21 - inibidor 1A da quinase dependente de ciclina

p300 - proteína de ligação ao E1A p300

p38 - proteína quinase ativada pelo mitógeno 14

p42/44 - proteína quinase 3 ativada pelo mitógeno

p90 rsk - proteína ribossomal de 90kDa S6 quinase

PAGE - eletroforese em gel de poliacrilamida (polyacrylamide gel electrophoresis)

PAK - proteína quinase p21 (Cdc42/Rac) ativada (p21 protein [Cdc42/Rac]-activated kinase)

PAK1 - proteína quinase p21 (Cdc42/Rac) ativada 1 (p21 protein [Cdc42/Rac]-activated kinase 1)

Par-4 - proteína de resposta a apoptose prostática (Prostate Apoptosis Response Protein 4)

PAWR- PRKC, apoptose, regulador do WT1 (PRKC, apoptosis, WT1, regulator)

$\mathrm{pb}$ - pares de base

PBS-A - tampão fosfato salino A (Phosphate-Buffered Saline - Solution A)

PCR- reação em cadeia pela polimerase (Polymerase Chain Reaction)

PD 98059 - 2-(2-amino-3-methoxyphenyl)-4H-1-benzopyran-4 one 
PDGF- Fator de crescimento derivado de plaquetas

pg- picograma

$\mathrm{pH}$ - potencial hidrogeniônico

$\mathrm{PH}$ - prolina-histidina

PHLDA1 - domínio homólogo à pleckstrina, família A, membro 1 (pleckstrin homology-like domain, family A, member 1)

PHLDA1- - PHLDA1 negativo

PHLDA1 + - PHLDA1 positivo

PI3-K - fosfatidilinositol 3 - quinase (Phosphatidylinositol 3 -Kinase)

PKA - proteína quinase A (Protein Kinase A)

PKB - proteína quinase B (Protein Kinase B). Sinônimo de Akt

PKC $\zeta$ - proteína quinase $\mathrm{C}$ zeta (Protein Kinase C zeta).

PLC - fosfolipase C (phospholipase C)

PLC- $\gamma$ - PLC gama

$\mathrm{PQ}$ - prolina-glutamina

PTEN - homólogo à fosfatase e tensina (Phosphatase and Tensin Homolog)

q- braço longo de um cromossomo

r.p.m. - rotações por minuto

Rac - sinônimo de Akt

RAF - homólogo 1 ao oncogene viral (v-raf-1) de leucemina murina. Proteína quinase quinase quinase ativada pelo mitógeno

RAS - homólogo ao oncogene viral de sarcoma de rato

REA - repressor da atividade do receptor de estrógeno (Repressor of Estrogen Receptor Activity)

RNA - ácido ribonucléico (Ribonucleic Acid)

RNAi - RNA de interferência

RPLP1 - proteína ribossomal P1 (ribosomal protein, large, P1)

RPMI-1640 - Roswell Park Memorial Institute -1640 (meio de cultura para células)

RT-PCR - transcriptase reversa - reação em cadeia pela polimerase (Reverse Transcriptase -

Polymerase Chain Reaction)

RYK - tirosina quinase RYK ( $R Y C$ receptor-like tyrosine kinase)

S - Serina

S6K - quinase ribossomal S6 (ribosomal S6 kinase)

SB 202190 - 4-[4-(4-Fluorophenyl)-5-(4-pyridinyl)-1H-imidazol-2-yl]phenol 
SC - Soro Carenciado

SDS - sódio dodecil sulfato

SERMs - modificadores seletivos do receptor de estrógeno (Selective Estrogen Receptor Modulators)

SHC - domínio contendo homologia a Src 2

SHP - receptor nuclear subfamília 0, grupo B, membro 2 (Short Heterodimer Partner)

Shp2 - proteína tirosina fosfatase

shRNA - pequeno grampo de RNA (short hairpin RNA)

siRNA - pequeno RNA de interferência (short interference RNA)

SMRT - co-repressor do receptor nuclear 2

SN - Soro Normal (soro sem tratamento com carvão dextrana)

Sos - homólogo de son of sevenless (son of sevenless homolog [Drosophila]). Fator de troca do nucleotídeo guanina

SP-1 - proteína específica 1 (Specificity Protein 1)

Src- homólogo ao oncogene viral src [Schmidt-Ruppin A-2] de sarcoma (aviário). Família de tirosinas quinase.

ST - Soro Tratado

STAT - transdutor de sinal e ativador da transcrição (Signal Transducer and Activator of Transcription)

STK11/LKB1 - serina/treonina quinase 11 (Serine/Threonine Kinase 11)

T- timina

$\mathrm{T}-155$ - tirosina 155

TAFII250 - TAF1 RNA polimerase II, fator associado à proteína de ligação ao TATA box (TAF1 RNA polymerase II, TATA box binding protein (TBP)-associatedfactor) Tam - tamoxifen

TAMOX- tamoxifen

TBE - Tris Borato EDTA

TDAG51 - gene 51 associado a morte de células T (T-cell Death-Associated Gene 51). Sinônimo de PHLDA1.

TEMED - N,N,N',N'- tetrametiletilenodiamino, N,N,N',N' - Di-(dimetilamino) etano ( $N, N, N$ ', $N$ '-Tetramethylethylenediamine, $N, N, N^{\prime}, N$ '-Di-(dimethylamino) ethane) ter- região telomérica do braço curto (pter) ou longo (qter) de um cromossomo TF - fator de transcrição (Transcription Factor)

TGF- $\alpha$ - fator de crescimento transformante alfa (Transforming Growth Factor alpha) 
TGF- $\beta$ - fator de crescimento transformante beta (Transforming Growth Factor beta)

TGFBR1 - recptor do fator de crescimento transformante beta 1 (Transforming Growth Factor, Beta Receptor 1)

TKR - receptor tirosina quinase (Tyrosine Kinase Receptor)

TNF- fator de necrose tumoral (Tumor Necrosis Factor)

TNFR1- Receptor da fator de necrose tumoral 1 (Tumor Necrosis Factor Receptor 1)

TP53 - proteína tumoral p53 (Tumor Protein p53)

TRAM1- proteína de membrana 1 associada a translocação (translocation associated membrane protein 1)

Tris - Tris (hidroximetil) amino metano

$\mathrm{U}$ - unidade

U- uracila

UNG - Uracil-N-Glicosilase

V - volts

Vav - fator vav1 de troca do nucleotídeo guanina

VEGFR-2 - receptor 2 do fator de crescimento endotelial vascular (Vascular Endothelial Growth Factor Receptor 2)

WT1- tumor de Wilms 1 (Wilms Tumor 1) 


\section{LISTA DE FÓRMULAS}

FÓRMULA MOLECULAR

$\mathrm{CO}_{2}$

$\mathrm{CaCl}_{2}$

$\mathrm{H}_{2} \mathrm{O}$

$\mathrm{HCl}$

$\mathrm{KCl}$

$\mathrm{KH}_{2} \mathrm{PO}_{4}$

$\mathrm{MgCl}_{2}$

$\mathrm{Na}_{2} \mathrm{PO}_{4} \cdot 2 \mathrm{H}_{2} \mathrm{O}$

$\mathrm{NaCl}$

$\mathrm{Na}_{4} \mathrm{P}_{2} \mathrm{O}_{7}$

$\mathrm{NaF}$

$\mathrm{Na}_{3} \mathrm{VO}_{4}$

$\mathrm{Na}_{2}$ EDTA

\section{NOME QUÍMICO}

gás carbônico

cloreto de cálcio

água

ácido clorídrico

cloreto de potássio

fosfato de potássio monobásico

cloreto de magnésio

fosfato dissódico 2-hidrato

cloreto de sódio

pirofosfato tetrasódico

fluoreto de sódio

ortovanadato de sódio

EDTA dissódico 


\section{SUMÁRIO}

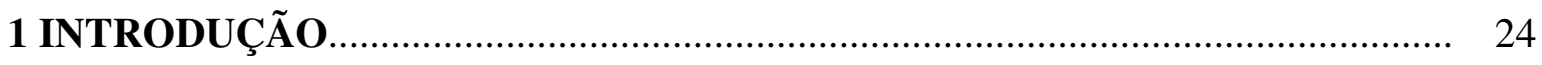

1.1 O Câncer de Mama: Etiologia e Fatores de Risco.............................................. 24

1.2 Genética do Câncer de Mama.......................................................................... 27

1.3 Sinalização Celular................................................................................. 30

1.3.1 Estrógenos e Fatores de Crescimento................................................................. 30

1.3.1.1 Os estrógenos e seus receptores.................................................................... 31

1.3.1.1.1 Mecanismos de Controle da Transcrição pelo ER........................................... 36

1.3.1.2 EGF e seus mecanismos de ação..................................................................... 41

1.3.2 Interação entre as vias de sinalização do ER e do EGFR ...................................... 45

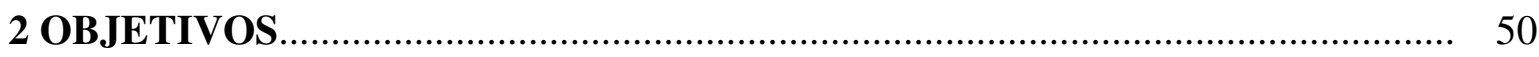

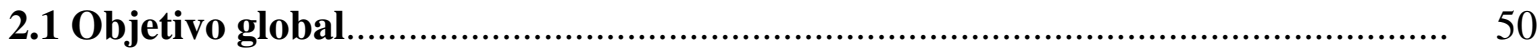

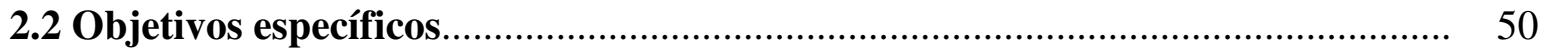

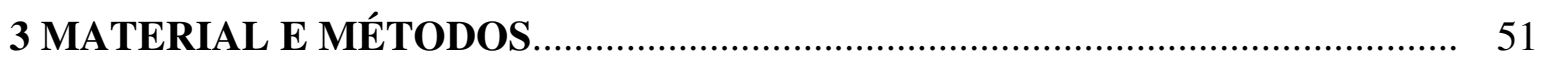

3.1 Material Biológico.......................................................................................... 51

3.2 Tratamento do Soro com Carvão Dextrana..................................................... 52

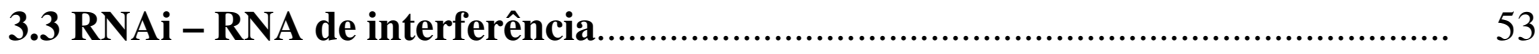

3.3.1 Supressão da expressão do gene ERa por siRNA inserido em vetor de

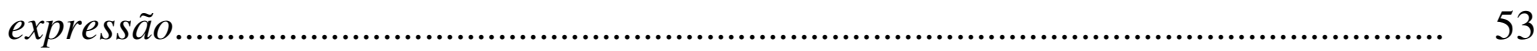

3.3.1.1 Transformação das bactérias competentes da linhagem XL1-Blue com os vetores de expressão contendo o siRNA para 0 gene $\mathrm{ER} \alpha$ e controle

3.3.1.2 Sensibilização das XL1-Blue Competent Cells para o processo de transformação..................................................................................................... 55

3.3.2 Supressão da expressão do gene ER $\mathrm{atilizando} \mathrm{siRNA} \mathrm{transiente.........................} 56$

3.4 Extração do RNA Total de Células em Cultura.................................................. 57

3.4.1 Tratamento do RNA com DNase I........................................................................ 58

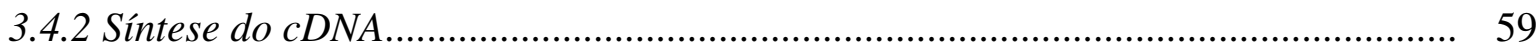

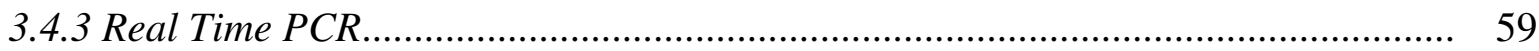

3.5 Extração das Proteínas............................................................................... 61

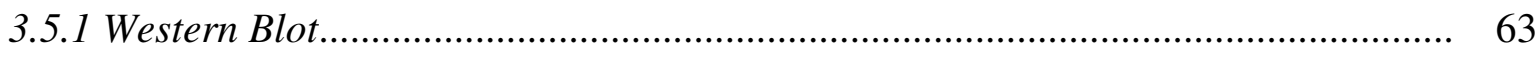

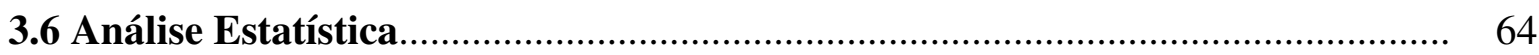


4 RESULTADOS

66

4.1 Padronização das condições de tratamento das células MCF-7.

4.1.1 Efeito do 17ß-estradiol (E2) e do ICI 182,780 na expressão dos genes PAWR e PHLDA1 72

4.1.2 Efeito do EGF e do ICI 182,780 na expressão dos genes PAWR e PHLDA1........ 76 4.1.3 Efeito do 17ß-estradiol (E2), EGF, ICI 182,780 e dos inibidores LY 294002, SB 202190 e PD 98059 na expressão dos genes PAWR e PHLDAl. 79

4.1.4 Efeito do 17ß-estradiol (E2), EGF, ICI 182,780 e PD 98059 na expressão das proteínas PAWR, PHLDA1, P-ER (S118), P-ERK1/2 e P-p38 MAPK 84

4.1.5 Supressão da expressão do gene ERa por RNA de interferência. 87

4.1.5.1 Supressão da expressão do gene $E R \alpha$ por siRNA inserido em vetor de expressão

4.1.5.2 Supressão da expressão do gene ER $\alpha$ utilizando siRNA transiente.

4.2 Efeito do EGF e do ICI 182,780 na expressão dos genes $P A W R$ e PHLDAI utilizando a linhagem celular MDA-MB-231

5 DISCUSSÃO 95

6 CONCLUSÕES. 104 


\section{INTRODUÇÃO}

\subsection{O Câncer de Mama: Etiologia e Fatores de Risco}

A incidência e mortalidade por câncer de mama têm diminuído nos últimos anos como resultado dos intensos programas de prevenção, utilizando a mamografia como ferramenta para o diagnóstico precoce, bem como dos progressos nos esquemas de tratamento (JEMAL et al., 2008). Apesar desta diminuição nas taxas de incidência e mortalidade, o câncer de mama continua sendo a neoplasia mais freqüente entre as mulheres americanas e européias (VARGO-GOGOLA e ROSEN, 2007; JEMAL et al., 2008; TRICHOPOULOS et al., 2008). Nos Estados Unidos, estima-se que, em 2008, esta doença será diagnosticada em 182.460 mulheres e será responsável por 40.480 óbitos (JEMAL et al., 2008).

No Brasil, segundo dados do Instituto Nacional do Câncer (INCA, 2008), entre as mulheres, esta é a segunda neoplasia mais freqüente depois do câncer de pele nãomelanoma sendo estimado para 2008 o registro de aproximadamente 49.400 novos casos, $57,5 \%$ destes na região sudeste.

A etiologia dos tumores de mama está relacionada a um complexo e heterogêneo conjunto de fatores de risco endógenos e exógenos o que confere a esta doença uma grande variabilidade histopatológica, genética e prognóstica (INGVARSSON, 1999; VARGO-GOGOLA e ROSEN, 2007).

Entre os fatores endógenos podem ser citados a história familiar, idade de ocorrência da menarca e da menopausa e densidade mamária. Como exemplos de fatores exógenos têm-se o uso de contraceptivos orais, terapia de reposição hormonal, prática de atividades físicas, condição sócio-econômica, gravidez e lactação prolongada.

A história familiar é o principal fator de risco para o câncer de mama e está relacionada à cerca de 5-10\% dos casos nos países ocidentais. Quando existe uma parente de primeiro grau (mãe, irmã ou filha) que desenvolveu a doença antes dos cinqüenta anos, o risco aumenta em torno de duas vezes e continua aumentando em função da menor idade da familiar no momento do diagnóstico e do desenvolvimento da doença em uma segunda parente de primeiro grau (McPHERSON; STEEL; DIXON, 2000).

A susceptibilidade ao câncer de mama é herdada de forma autossômica dominante e pode ser transmitida por ambos os sexos sem que, necessariamente, o progenitor tenha desenvolvido a doença (EASTON et al., 1993; McPHERSON; STEEL; DIXON, 2000). Mutações em genes autossômicos dominantes, como o BRCA1, BRCA2, TP53, PTEN, ATM e 
STK11/LKB1, têm sido relacionadas ao câncer de mama familiar (MINCEY, 2003; TRICHOPOULOS et al., 2008).

Entretanto, 80-95\% dos casos não apresentam relação familiar, ou seja, são esporádicos e estão relacionados principalmente à exposição do tecido mamário aos estrógenos. Desse modo, a ocorrência de menarca precoce e/ou menopausa tardia, bem como o uso de contraceptivos orais e da terapia de reposição hormonal estão associados ao aumento do risco. A prática de atividades físicas e a lactação prolongada estão associadas a uma diminuição no risco de desenvolvimento desta neoplasia (OLSSON, 2000; McPHERSON; STEEL; DIXON, 2000; PAGE FOR PATIENTS, 2000; MITRUNEN e HIRVONEN, 2003). O impacto da gravidez no aumento ou diminuição do risco de desenvolvimento do câncer de mama ainda não é bem compreendido. Estudos mostram que, independentemente da idade da mulher, a gravidez promove um aumento do risco à curto prazo seguido por uma substancial redução do risco à longo prazo. $\mathrm{O}$ aumento do risco à curto prazo está relacionado a ação dos fatores de crescimento na glândula mamária com o objetivo de promover sua completa diferenciação. Como conseqüência, células já alteradas ao longo da vida podem ser multiplicadas. Entretanto, após essa diferenciação, as células tornam-se menos susceptíveis às transformações carcinogênicas. Dessa maneira pode-se inferir que quanto menor a idade da mulher na primeira gravidez mais precoce será a diferenciação completa da mama e, consequentemente, menor a chance de ocorrência de mutações nas células imaturas e maior o tempo que a mulher usufruirá deste efeito protetor (TRICHOPOULOS et al., 2008).

Outros fatores associados ao aumento do risco de desenvolvimento do câncer de mama são: idade (a incidência aumenta com a idade e diminui após a menopausa); desenvolvimento de doença benigna prévia levando a alterações proliferativas na mama; irradiação da mama durante a infância ou adolescência; alta densidade mamográfica (relação tecido mamário / tecido adiposo); e estilo de vida incluindo melhor condição sócio-econômica (McPHERSON; STEEL; DIXON, 2000; OLSSON, 2000; PAGE FOR PATIENTS, 2000; MITRUNEN e HIRVONEN, 2003).

Sobre o estilo de vida, não existe relação consistente entre dieta rica em gordura e câncer de mama embora a incidência desta doença seja menor em países cuja dieta é pobre em gordura (NOGUEIRA e APPLING, 2000) e a obesidade esteja relacionada a um pior prognóstico para esta neoplasia entre as mulheres na pós-menopausa devido à biossíntese de estrógenos a partir dos andrógenos no tecido adiposo (MAEHLE et al., 2001; MITRUNEN e HIRVONEN, 2003; TRAVIS e KEY, 2003). Olsen et al. (2003) observaram que uma maior ingestão de frutas e vegetais está associada a uma menor incidência de tumores de mama ER- 
negativos, embora nenhuma relação tenha sido encontrada entre a ingestão destes alimentos e a prevenção do câncer de mama. Entretanto, novos estudos são necessários para se determinar os efeitos destes alimentos na progressão do câncer de mama, pois os resultados obtidos até o momento são controversos.

Quanto ao consumo de tabaco e álcool, estudos mostram que a relação entre o tabaco e a etiologia do câncer de mama ainda não está bem determinada (PERSSON, 2000; COUCH et al., 2001), enquanto o álcool é considerado um fator de risco dose-dependente, ou seja, o risco aumenta com o aumento do consumo (FENTIMAN, 2000; McPHERSON; STEEL; DIXON, 2000; PERSSON, 2000; ARONSON, 2003). O álcool atua como fator de risco, pois aumenta os níveis de estrógenos, interfere nos mecanismos de reparo do DNA e eleva a atividade transcricional do $\mathrm{ER} \alpha$ (Receptor de Estrógeno alfa). Este aumento na atividade transcricional do $\mathrm{ER} \alpha$ pode ser intensificado pelo fato do etanol promover a diminuição da expressão do gene $B R C A l$ que, por sua vez, é um potente inibidor da atividade transcricional do $\mathrm{ER} \alpha$ além de participar dos mecanismos de reparo do DNA. Em adição, o acetaldeído originado no processo de metabolização do etanol é um composto intermediário eletrofílico que tem sido classificado como um co-carcinógeno, pois radicais livres potencialmente mutagênicos podem ser formados quando há um consumo excessivo de álcool e, conseqüentemente, maior demanda de acetaldeído para ser detoxificado (FAN et al., 2000; WELCSH e KING, 2001; ARONSON, 2003; CHEN e COLDITZ, 2007).

Uma melhor condição sócio-econômica está associada ao aumento do risco de desenvolvimento do câncer de mama devido à maior ocorrência de nuliparidade, primeira gravidez tardia e maior consumo de hormônios sintéticos entre as mulheres pertencentes a este grupo social (MITRUNEN e HIRVONEN, 2003).

Os fatores ambientais são de grande importância na etiologia do câncer de mama. Um estudo realizado com imigrantes japoneses no Havaí mostrou que, após uma ou duas gerações, a incidência desta neoplasia nos imigrantes torna-se equivalente à observada na população havaiana. Existe também uma significante variação geográfica no índice de mortalidade por câncer de mama: a menor mortalidade é observada em Gâmbia na África (3,4 em 100.000 mulheres) e a maior nas mulheres brancas dos Estados Unidos (89,2 em 100.000 mulheres) (McPHERSON; STEEL; DIXON, 2000). 


\subsection{Genética do Câncer de Mama}

O câncer de mama, assim como a maioria dos outros tipos de câncer, é uma doença genética que apresenta uma evolução clonal (Figura 1), isto é, o tumor se origina de uma única célula que sofreu uma alteração genética, tornando-se instável e, portanto, mais susceptível a novas alterações. Essa alteração é então transmitida às células filhas, que por sua vez, também se tornam instáveis e, conseqüentemente, podem sofrer novas alterações genéticas de modo que, com o decorrer das divisões celulares, ocorre a formação de um conjunto de diferentes clones com diferentes alterações genéticas e com vantagens de crescimento sobre as demais células (NOWELL, 1976; CAVENEE e WHITE, 1995; BARCUS et al., 2000; ZHOU et al., 2009). Essas alterações incluem deleções cromossômicas, translocações, inversões, amplificações, duplicações, aneuploidias, formação de isocromossomos, mutações de ponto bem como alterações epigenéticas e conduzem à ativação de oncogenes e a inativação de genes supressores de tumor (LEREBOURS e LIDEREAU, 2002; POPESCU e ZIMONJIC, 2002; BERTUCCI et al., 2003).

Diante da grande diversidade de alterações genéticas envolvidas na tumorigênese mamária, alguns modelos de progressão têm sido propostos. A figura 2 representa o modelo de progressão proposto por Bièche e Lidereau (1995) no qual são apontadas as alterações genéticas que caracterizam as diversas etapas da progressão do câncer de mama sem levar em conta a heterogeneidade bioquímica, histológica, clínica e geográfica deste tumor.

Alguns estudos investigam a possibilidade de diferentes polimorfismos genéticos nas enzimas que participam da biossíntese e do metabolismo dos estrógenos bem como do metabolismo dos carcinógenos químicos, entre elas a CYP1A1, 17- $\beta H S D, M n S O D$, NAT1, NAT2, GSTM1, etc, interferirem na etiologia, agressividade e resposta do tumor à terapia (COUGHLIN e PIPER, 1999; KRISTENSEN e BORRESEN-DALE, 2000; MITRUNEN e HIRVONEN, 2003; PARL et al., 2009).

Tendo em vista a capacidade de divisão ilimitada e de diferenciação inerentes às células tronco adultas normais, atualmente tem sido estudada a hipótese de que a ocorrência de alterações genéticas e epigenéticas nestas células estariam diretamente relacionadas à origem do tumor bem como à sua progressão e recorrência. Embora este conceito e sua implicação clínica ainda não estejam bem determinados, estudos detectaram a presença de células tronco tumorais em diversas neoplasias, tais como: leucemias, tumores de mama e tumores cerebrais (TAN et al., 2006; VARGO-GOGOLA e ROSEN, 2007). 


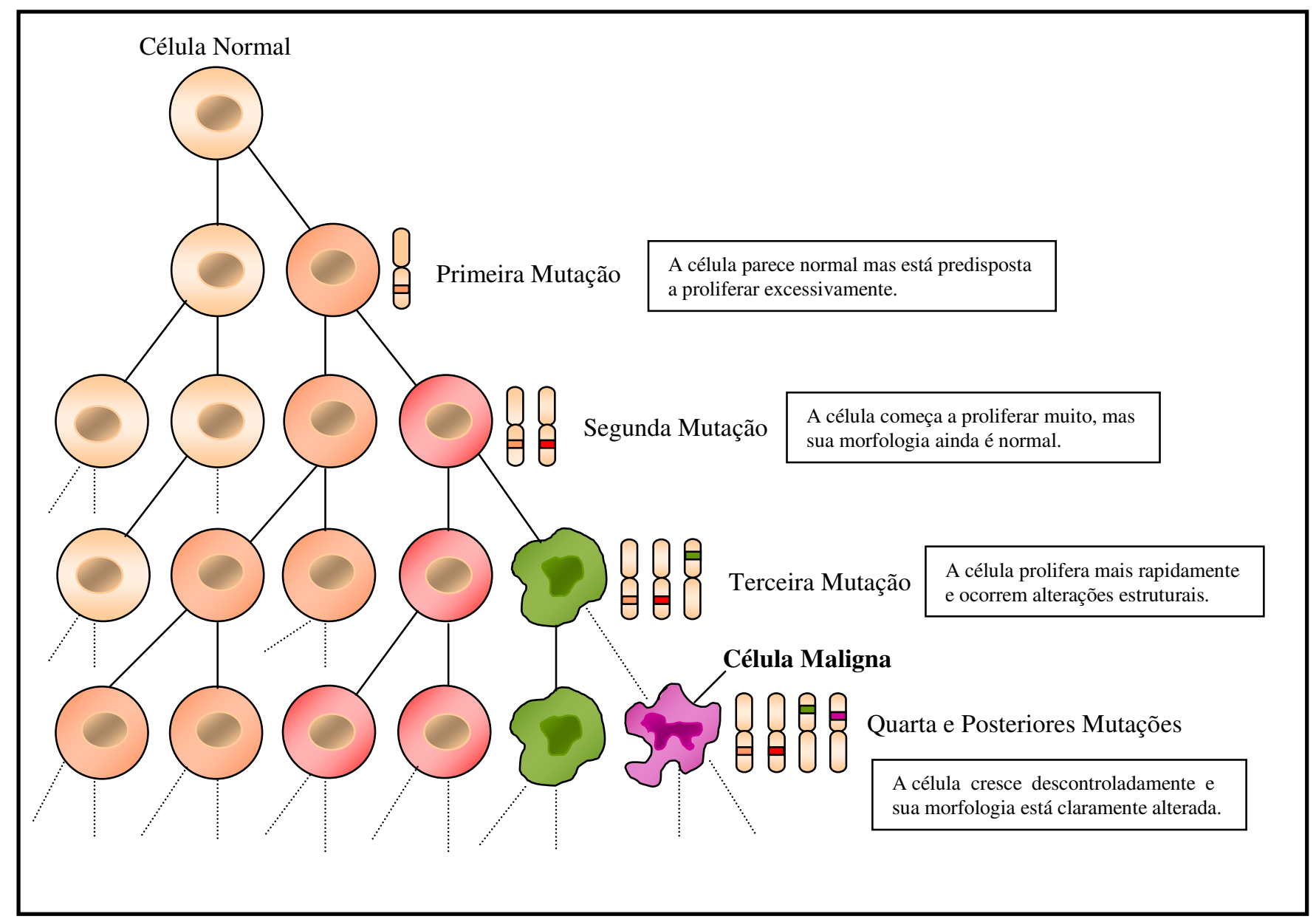

Figura 1. Processo de evolução clonal. Uma célula-filha normal (bege) adquire uma mutação (laranja) que será transmitida para as gerações seguintes. Em algum momento, uma das células descendentes (vermelho) adquire uma segunda mutação, outra célula descendente desta (verde) adquire uma terceira e assim sucessivamente. Deste modo, com o decorrer das divisões celulares, uma célula (roxo) acaba por acumular mutações iniciando, assim, o processo de tumorigênese.

FONTE: Modificado de Cavenee, W.K. e White, R.L., 1995. 


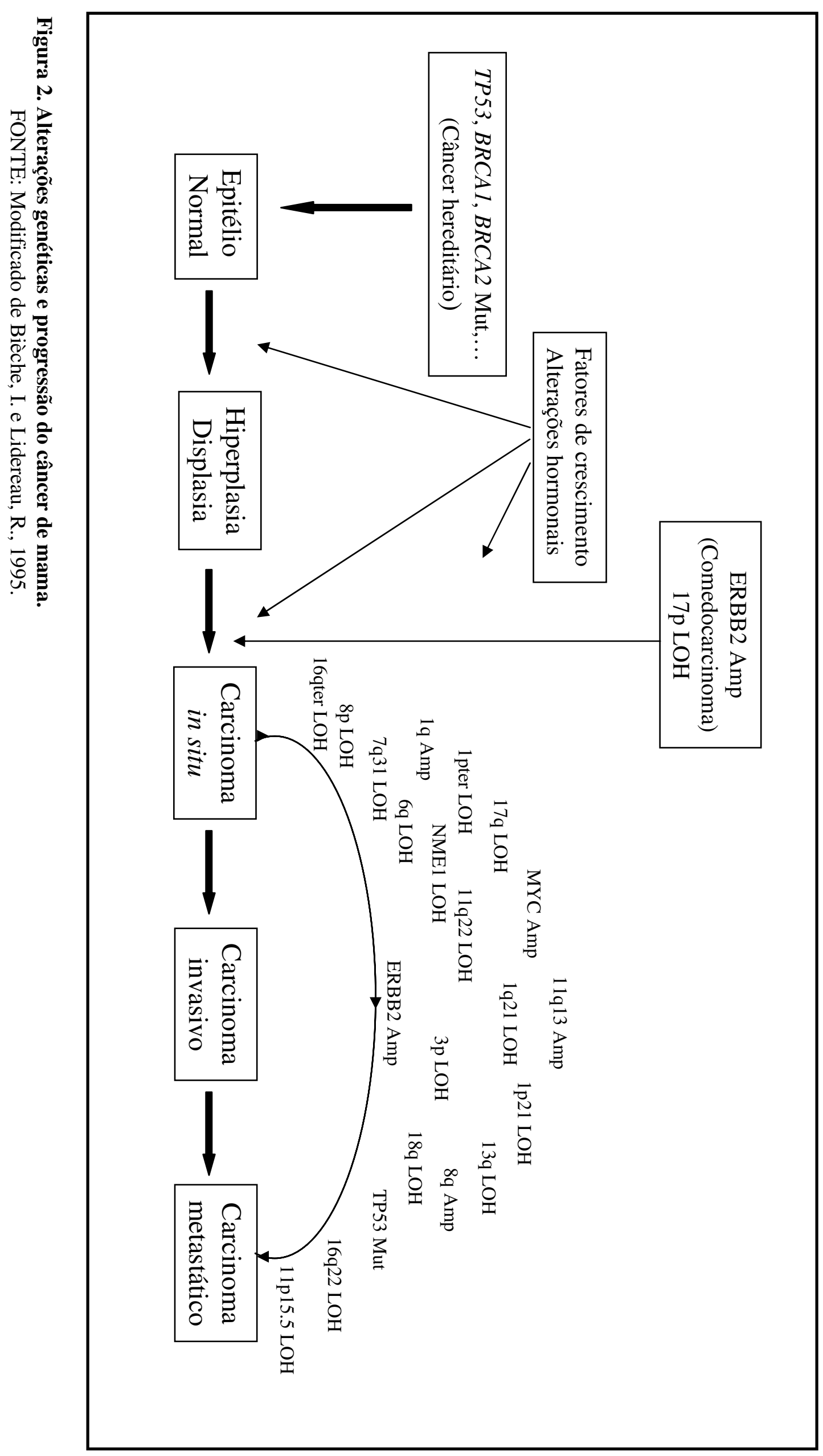




\subsection{Sinalização Celular}

A sinalização celular pode ocorrer através da interação direta entre uma célula e a célula adjacente ou através da ação de moléculas secretadas. Existe uma grande variabilidade na estrutura e na função das moléculas responsáveis pela transmissão de informações entre as células de organismos multicelulares. Em comum, estas moléculas apresentam a característica de atuarem como ligantes que exercem seus efeitos sobre as células-alvo por intermédio de seus receptores os quais, em sua maioria, são expressos na superfície celular enquanto outros estão presentes no citoplasma ou no núcleo (COOPER, 2000).

A sinalização celular é dividida em três categorias: sinalização endócrina, na qual as moléculas sinalizadoras são produzidas por células especializadas e secretadas no sangue atuando em sítios distantes do corpo (como exemplos, têm-se os hormônios esteroídicos e alguns fatores de crescimento como o IGF-1); sinalização parácrina, na qual as moléculas são secretadas por uma célula para atuar sobre as células vizinhas (como exemplos podem ser citados os neurotransmissores e alguns fatores de crescimento como o EGF e o PDGF); e sinalização autócrina, na qual a célula secreta moléculas que irão atuar sobre si própria (fatores de crescimento como o EGF, por exemplo) (COOPER, 2000).

\subsubsection{Estrógenos e Fatores de Crescimento}

Os estrógenos e seus receptores (ER, receptor de estrógeno) são importantes reguladores fisiológicos no sistema reprodutor, no metabolismo ósseo e na manutenção dos sistemas nervoso e cardiovascular, sendo também considerados fatores dominantes na etiologia e progressão do câncer de mama bem como de outros tumores hormôniodependentes (KING e WILLIAM, 1993; HAYASHI et al., 2003; SHAO e BROWN, 2004). Basicamente três tipos de estrógenos produzidos pelos ovários estão presentes em grandes quantidades no plasma das mulheres: o estradiol (estrógeno biologicamente mais ativo, cuja concentração fisiológica varia de 20-400,0 pg/ml dependendo da fase do ciclo menstrual), a estrona e o estriol (estrógeno pouco ativo derivado da oxidação do estradiol e da estrona) (GUYTON, 1993; BRAGA FILHO, 2008). Estes hormônios são substâncias lipofílicas que penetram no citoplasma e no núcleo celular por difusão através das membranas (ANDERSON, 2002). 
Diversos estudos experimentais mostram que os estrógenos apresentam efeitos mitogênicos em linhagens celulares derivadas de tumores de mama aumentando, assim, a probabilidade de ocorrência de alterações genéticas e promovendo a replicação das células alteradas. Além disso, alguns genes envolvidos na progressão da fase $\mathrm{G}$ para a fase $\mathrm{S}$ do ciclo celular, tais como: fos, jun, c-myc, CCND1 e p21, bem como fatores de crescimento e seus receptores, têm sua função e expressão reguladas por estrógenos (TRAVERS e KNOWLER, 1987; DICKSON; THOMPSON; LIPPMAN, 1990; SCHUCHARD et al., 1993; CHARPENTIER et al., 2000; DOISNEAU-SIXOU et al., 2003).

Apesar do efeito dominante dos estrógenos, os fatores de crescimento e seus receptores também são importantes reguladores no processo de desenvolvimento e diferenciação da mama normal bem como na progressão do câncer de mama. Como exemplos de fatores de crescimento podem ser citados o NGF (fator de crescimento de nervos), o EGF (fator de crescimento epidermal), o IGF-1 (fator de crescimento semelhante à insulina 1), o PDGF (fator de crescimento derivado de plaquetas) e as citocinas (COOPER, 2000; CITRI e YARDEN, 2006).

Estudos mostram que a interação entre as vias de sinalização dos estrógenos e dos fatores de crescimento está relacionada ao aumento da proliferação e sobrevivência das células tumorais, além de contribuir para o desenvolvimento da resistência aos tratamentos hormonais (LUNDHOLT; BRIAND; LYKKESFELDT, 2001; OSBORNE e SCHIFF, 2003).

\subsubsection{Os estrógenos e seus receptores}

Os estrógenos exercem diversos efeitos sobre seus tecidos alvos por intermédio dos receptores de estrógeno: $\operatorname{ER} \alpha$ e $\operatorname{ER} \beta$ (receptor de estrógeno beta) (Figura 3). Estes receptores pertencem à super-família de receptores nucleares, a qual inclui os receptores para os andrógenos, progestinas, glicocorticóides, mineralocorticóides, retinóides, vitamina D e hormônios tiroideanos (RIBEIRO; KUSHNER; BAXTER, 1995). O ER $\alpha$ e o ER $\beta$ atuam como fatores de transcrição regulados alostericamente pela ligação com o hormônio e exercem seus efeitos de maneira ligante-dependente, ligante-independente ou através da interação com outras vias de sinalização (GUSTAFSSON e WARNER, 2000; ARANDA e PASCUAL, 2001). O ER $\alpha$ ou ESRl(6q25), receptor clássico, é expresso na mama, no útero, colo do útero, vagina, placenta, fígado, glândulas adrenais, bexiga e nos sistemas 


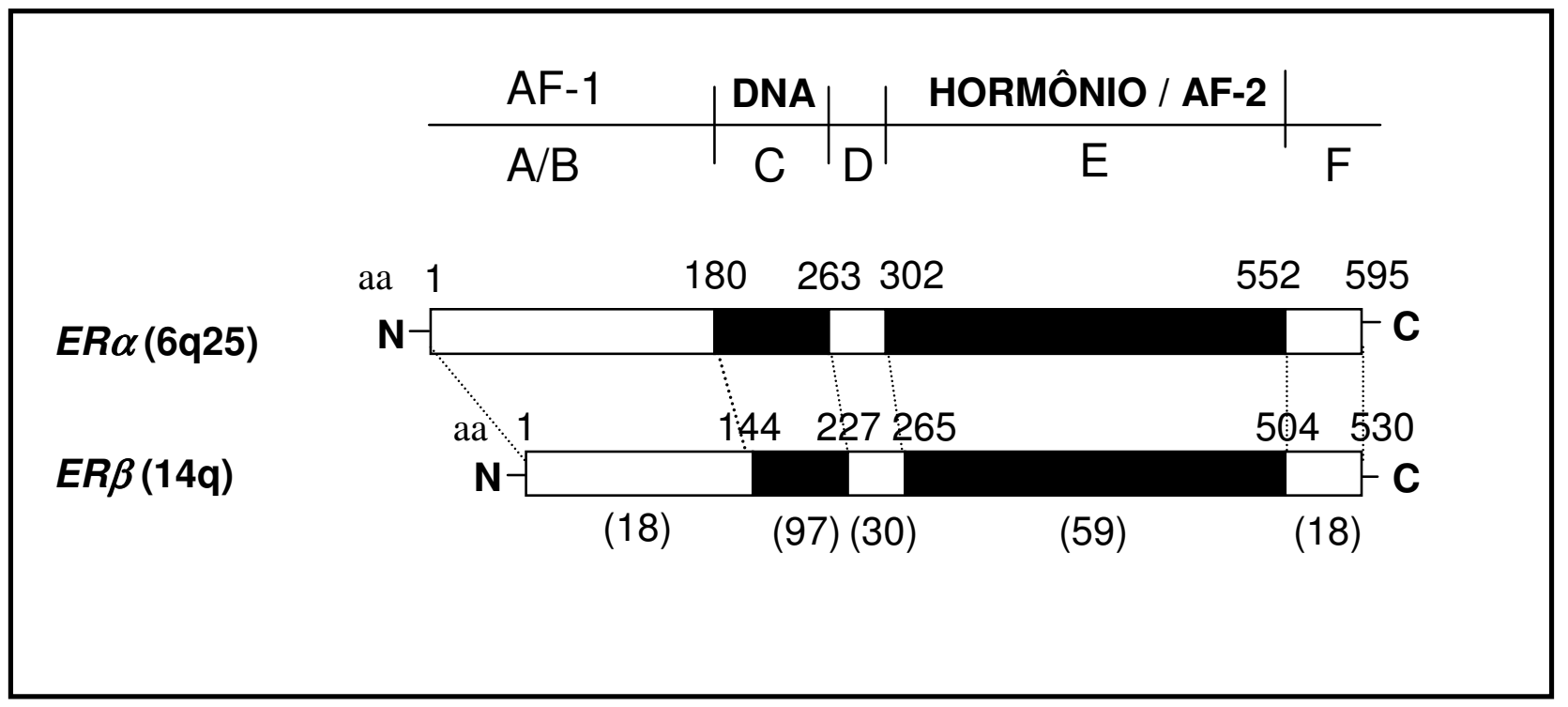

Figura 3. Representação esquemática do receptor de estrógeno humano alfa e do receptor de estrógeno humano beta. Os domínios estruturais destes receptores (A/B, C, D, E e F), bem como os domínios de ligação ao hormônio e ao DNA, os domínios funcionais de transativação (AF-1 e AF-2) e o percentual de similaridade da sequência de aminoácidos de cada domínio entre os dois receptores (números entre parênteses) são mostrados. aa, aminoácido; AF, função de ativação.

FONTE: Modificado de Katzenellenbongen, B.S. et al., 2000. 
cardiovascular, esquelético e nervoso central. A expressão do $E R \beta$ ou $E S R 2$ (14q) é encontrada na mama, nos ovários, próstata, testículos, trato urogenital, sistema cardiovascular, músculos, baço, pulmões, hipotálamo, tireóide e timo (HALL; COUSE; KORACH, 2001; SHAW et al., 2002; WEIHUA et al., 2003).

Alguns genes regulados pelo $\mathrm{ER} \alpha$ podem ser ativados, de maneira menos eficiente, pelo ER $\beta$ enquanto outros são regulados por apenas um dos receptores. Estudos mostram que, em algumas ocasiões, o ER $\beta$ parece atuar como um antagonista das ações do $\mathrm{ER} \alpha$ inibindo a transativação de genes dependentes do $\mathrm{ER} \alpha$ como o $C C N D 1, C C N A$ e $c$-myc os quais são genes envolvidos na progressão do ciclo celular (MCDONNEL e NORRIS, 2002; KIAN TEE et al., 2003; WEIHUA et al., 2003). Paruthiyil et al. (2004) mostraram que, nas células MCF-7, esta ação antagonista do ER $\beta$ pode estar relacionada à inibição da proliferação celular e à inibição da formação do tumor.

A molécula de ambos receptores possui um padrão modular que inclui seis domínios estruturais, denominados de A a F (Figura 4). O domínio A/B, localizado na região amino-terminal, apresenta grande variabilidade entre os diversos receptores esteroídicos e contém, no $\mathrm{ER} \alpha$ mas não no ER $\beta$, o domínio de transativação hormônio independente $\mathrm{AF}-1$ (função de ativação 1); o domínio $\mathrm{C}$, localizado na região central da molécula, contém o domínio de ligação ao DNA (DBD) com dois dedos de zinco e é de fundamental importância para a ativação da transcrição (por ser o domínio responsável pelo reconhecimento do ERE, elemento responsivo ao estrógeno, na região promotora dos genes alvos) e para a localização nuclear do ER; o domínio D está relacionado a atuação das proteínas co-regulatórias (repressoras e ativadoras) e o domínio E/F, localizado na região carboxi-terminal, contém sítios relacionados à ligação de proteínas co-regulatórias, o domínio de ligação ao ligante (LBD), uma região de ligação para proteínas de choque térmico e um outro sinal de localização nuclear (KUMAR et al., 1987; PICARD e YAMAMOTO, 1987; WHITE e PARKER, 1998; HALL; COUSE; KORACH, 2001; SOMMER e FUQUA, 2001; MCDONNELL et al., 2002).

O ERE na região promotora dos genes alvos do ER é representado por palíndromes perfeitas (como, por exemplo, 5'-GGTCANNNTGACC-3'), palíndromes imperfeitas, meios EREs e repetições diretas de meios EREs (BERRY; NUNEZ e CHAMBON, 1989; KATO et al., 1992; DANA et al., 1994; KATO et al., 1995; AUMAIS et 


\section{DOMÍNIOS DO RECEPTOR}

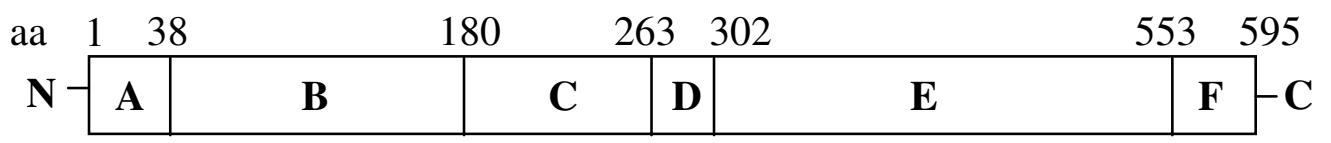

\section{FUNÇÃO}

Transativação

AF-1

AF-2a/b AF-2/AF-2b

Dimerização

Ligação ao DNA

Ligação ao hormônio

Ligação à Hsp 90

Ligação de co-ativadores

Ligação de co-repressores

Figura 4. Representação esquemática dos domínios estruturais e funcionais do ER. O receptor é constituído de 595 aminoácidos divididos em seis domínios estruturais, A-F, os quais contêm diversos domínios funcionais como indicado abaixo do esquema estrutural. aa, aminoácido; AF, função de ativação.

FONTE: Modificado de Sommer, S. e Fuqua, A.A.W., 2001. 
al., 1996). O LBD apresenta os domínios de transativação AF-2, AF-2a (aa282-351) o qual é necessário para a completa atividade transcricional do ER (NORRIS et al., 1997; SOMMER e FUQUA, 2001) e AF-2b (aa351, 538,542 e 545) que é um sítio relacionado às ações estrogênicas do tamoxifen, pois a ele se ligam co-ativadores quando ocorre a formação do complexo ER-tamoxifen (MACGREGOR SCHAFER et al., 2000; JORDAN et al., 2001). Os domínios AF-1, AF-2, AF-2a e AF-2b mediam a ativação transcricional dos genes regulados pelo ER e podem atuar de maneira sinérgica ou independente em função do tipo celular e dos tipos de proteínas co-regulatórias expressas por estas células (MCDONNELL et al., 2002; SOMMER e FUQUA, 2001).

Como pode ser observado na figura 4, existe grande similaridade entre o DBD dos dois tipos de ER enquanto o LBD e as regiões terminais AF-1 e AF-2 apresentam uma menor similaridade. Este fato sugere que ambos receptores reconhecem e se ligam a EREs semelhantes mas interagem com diferentes ligantes e diferentes proteínas dos complexos transcricionais. Como exemplo destas diferenças pode ser citada a ação transcricional do sítio AP-1: dependendo da região promotora na qual este sítio está situado, a ligação do complexo $\mathrm{ER} \alpha+\mathrm{E} 2$ promove a ativação transcricional do gene alvo, enquanto a ligação do complexo ER $\beta+E 2$ promove a repressão transcricional (PAECH et al., 1997).

As proteínas co-regulatórias, também chamadas de co-fatores, podem ser coativadoras (CBP/p300, p/CAF, TAFII250, família p160 - AIB1, SRC, TRAM1, etc - entre outras) ou co-repressoras (N-COR, SMRT, REA, SHP, DAX-1, etc) e participam da acetilação e deacetilação de histonas, respectivamente, bem como da transmissão da informação regulatória do ER para o aparato transcricional da célula. Além disso, estas proteínas estão relacionadas ao desenvolvimento do câncer de mama e à resistência ao tratamento hormonal (PAIGE et al., 1999; ARANDA e PASCUAL, 2001; SOMMER e FUQUA, 2001; ARPINO et al., 2008). Algumas proteínas co-repressoras competem com as co-ativadoras pela ligação ao complexo ER+agonista e algumas proteínas co-ativadoras regulam e interagem diretamente com o domínio AF-1 do receptor de estrógeno (SHAO e BROWN, 2004). Assim, diferenças na funcionalidade e na expressão das proteínas coregulatórias entre os diferentes tipos de células, modulam a atividade dos ligantes do ER e podem ser responsáveis pelas respostas tecido-específicas aos diferentes complexos ERligante (SOMMER e FUQUA, 2001; MCDONNELL et al., 2002). 


\subsection{Mecanismos de Controle da Transcrição pelo ER}

O controle da transcrição pelo ER pode ocorrer de maneira ligante dependente (através dos modelos clássico e não-clássico), de maneira ligante independente e de maneira não-genômica (Figura 5). Quando o receptor não está ativado pelo ligante ele se encontra associado a uma proteína de choque térmico cuja função é evitar a ocorrência de alterações conformacionais no ER que prejudiquem a ligação dos hormônios e, conseqüentemente, a resposta ao estímulo hormonal (LEWIN, 2000; BOHEN; KRALLI; YAMAMOTO, 1995; BRENTANI e FELDMAN, 1995; SOMMER e FUQUA, 2001).

De acordo com o modelo clássico, a ligação do hormônio provoca alterações conformacionais no receptor promovendo a sua dimerização $(E R \alpha / \alpha, E R \beta / \beta$ ou $E R \alpha / \beta)$, a dissociação das proteínas de choque térmico (como a hsp70 e hsp90) e a associação de determinadas proteínas co-regulatórias. O complexo ER - hormônio - proteínas coregulatórias liga-se ao ERE adjacente ao gene alvo e interage com fatores de transcrição e histonas estimulando ou inibindo a transcrição gênica (WHITE e PARKER, 1998; HALL; COUSE; KORACH, 2001; SOMMER e FUQUA, 2001; SHAO e BROWN, 2004). No modelo não-clássico de ativação, a ligação do hormônio promove a interação do ER com outros fatores de transcrição, como o AP-1, SP-1, NF- $\kappa$ B e jun/ATF-2, influenciando dessa maneira a atividade transcricional de genes que não contêm o ERE mas, que apresentam sítios de reconhecimento para estes outros fatores como é o caso do c-myc e IGF-BP4 (HALL; COUSE; KORACH, 2001; SOMMER e FUQUA, 2001; MCDONNEL e NORRIS, 2002).

Alguns dos compostos utilizados na terapia endócrina são os antiestrógenos tamoxifen, raloxifen e o fulvestrant (ICI 182,780). O tamoxifen e o raloxifen imitam ou opõem-se aos efeitos dos estrógenos em função do tecido alvo sendo, por isso, denominados de modificadores seletivos do receptor de estrógeno (SERMs). O tamoxifen, cuja dose terapêutica recomendada para as pacientes é de $20,0 \mathrm{mg}$ ou $40,0 \mathrm{mg}$ por dia via oral (RXLIST, 2008), apresenta atividade antagonista na mama, mas mantêm os efeitos agonistas dos estrógenos nos sistemas esquelético, cardiovascular e tecido uterino. O raloxifen, cuja dose recomendada é de 60,0 mg por dia via oral (RXLIST, 2008), apresenta as mesmas características do tamoxifen exceto por exercer atividade antagonista no tecido uterino (LEMIEUX e FUQUA, 1996; GRADISHAR e JORDAN, 1999; MANNI, 1999; PAIGE et al., 1999; HALL; COUSE; KORACH, 2001). Os antiestrógenos atuam como inibidores competitivos da ação dos estrógenos via ER. O tamoxifen, por exemplo, é um antagonista do domínio AF-2 do ER. Assim, nas células onde o AF-2 é necessário para 


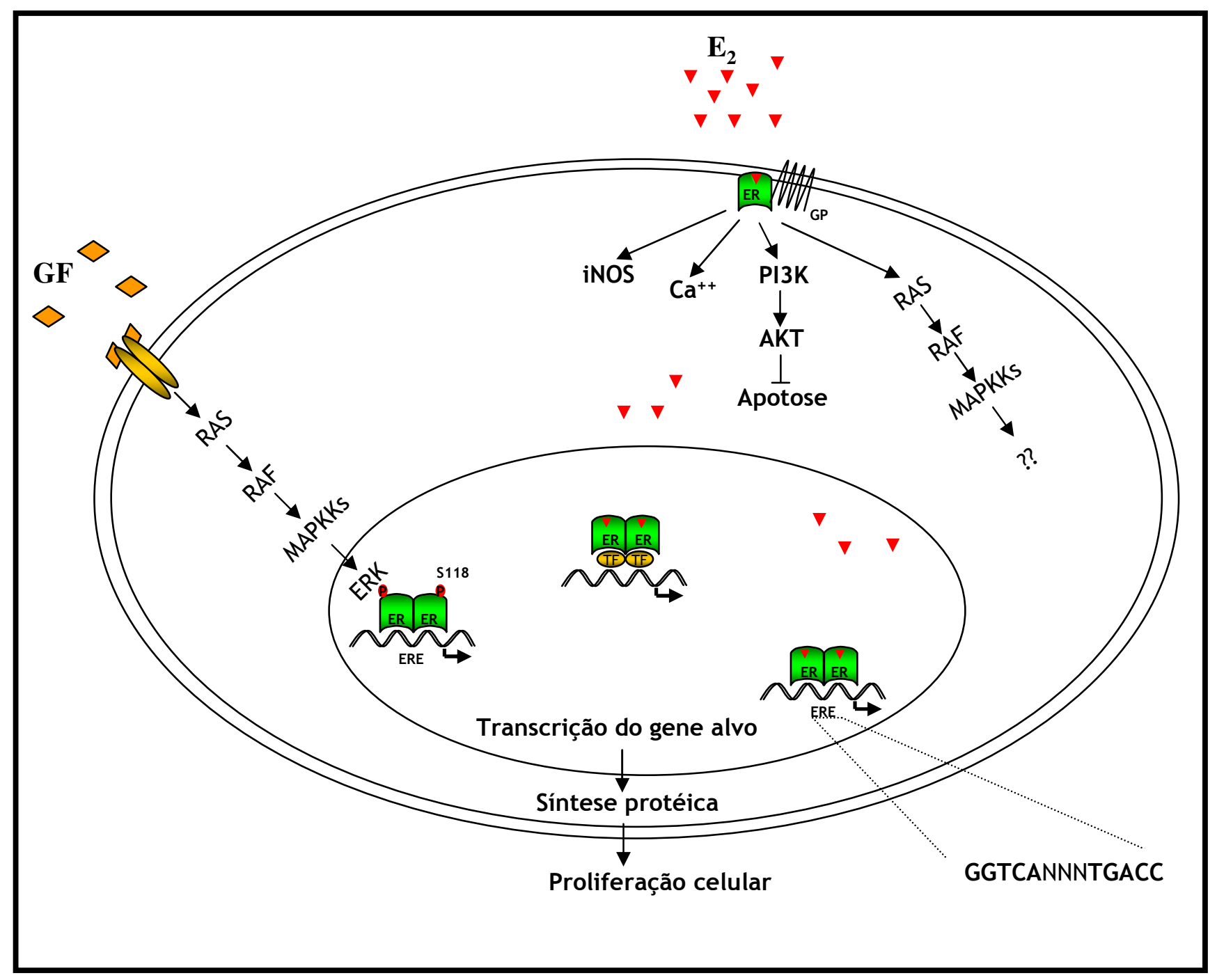

Figura 5. Mecanismos de ativação da transcrição pelo ER. Os efeitos biológicos do estradiol (E2) são mediados por, pelo menos, quatro mecanismos. 1, Clássico (ligante-dependente), o complexo E2ER (receptor de estrógeno) se liga ao ERE (elemento responsivo ao estrógeno) localizado na região promotora do gene alvo, conduzindo ao aumento ou diminuição da transcrição gênica. 2, Ligante-independente, fatores de crescimento (GF) ativam vias intracelulares de quinases, conduzindo à fosforilação $(\mathrm{P})$, ativação e ligação do ER nas regiões promotoras que contêm $\mathrm{o}$ ERE. 3, Independente do ERE, os complexos E2-ER alteram a transcrição de genes que contêm elementos responsivos alternativos através da associação com fatores de transcrição (TF) ligados ao DNA. 4, Não-genômico, o E2 ativa formas do ER localizadas na membrana citoplasmática e relacionadas a vias de transdução de sinal intracelulares, gerando uma resposta tecidual rápida. GP, proteínas G; S, serina.

FONTE: Modificado de Nagai, M.A. e Brentani, M.M., 2008. 
que o ER exerça sua atividade transcricional, a ligação do tamoxifen promove uma alteração conformacional que impede a interação do AF-2 com determinados co-fatores e, consequientemente, inibe sua atividade transcricional. Nos tecidos onde o AF-1, isoladamente, é suficiente para que o ER exerça sua atividade, como no caso do útero, o tamoxifen atuará como agonista. Já os antiestrógenos puros como, o ICI 182, 780 (Fulvestrant), inibem a atividade transcricional de ambos AFs (MCDONNELL et al., 2002; SHAO e BROWN, 2004).

O ICI 182,780, cuja dose terapêutica é de $250,0 \mathrm{mg}$ por mês via intramuscular (RXLIST, 2008), é um antagonista do ER que, assim como o tamoxifen, competitivamente inibe a ligação do estradiol ao ER. Em relação ao tamoxifen, o ICI possui uma maior afinidade de ligação ao receptor e sua ligação promove uma alteração conformacional que resulta na inibição da dimerização do receptor, na redução da migração do complexo drogareceptor para o núcleo e na diminuição da meia-vida da proteína ER. Com a diminuição da sua meia-vida, o ER é rapidamente conduzido às vias de degradação resultando na diminuição dos níveis intracelulares de ER. Ao contrário do tamoxifen, que inibe somente a atividade transcricional do domínio AF-2 - permitindo assim a ativação do domínio AF-1, a dimerização do receptor e sua ligação a genes regulados pelo estrógeno - qualquer complexo ICI-ER que migra para o núcleo é transcricionalmente inativo já que ambos os domínios, AF1 e AF-2, são inibidos (DOWSETT; NICHOLSON; PIETRAS, 2005; HOWELL, 2006).

A ativação ligante-independente ocorre através da fosforilação de vários resíduos de serina, tirosina e treonina presentes nos domínios AF-1 (principalmente as serinas 106/107, 118, 167, 305 e treonina 311) e AF-2 do ER. Esta fosforilação é promovida pela ativação das vias p42/44 MAPK, PI3K/AKT, p90rsk, PAK1, PKA, p38 MAPK, e por sinais provenientes das vias dos receptores de fatores de crescimento como o EGFR, o IGFR, o ERBB2, do receptor de insulina, e de outras moléculas como citocinas, cAMP e dopamina. Uma vez fosforilado, o ER se torna ativado e, conseqüentemente, dimeriza-se e se associa às proteínas co-regulatórias para, então, atuar na regulação da transcrição gênica independentemente da ligação do hormônio (HALL; COUSE; KORACH, 2001; SOMMER e FUQUA, 2001; FENG et al., 2001; JORDAN, 2002; ARPINO et al., 2008). As vias relacionadas à ativação ligante-independente podem influenciar a atividade transcricional do ER de forma direta, como descrito acima, ou regulando a atividade das proteínas coregulatórias (SHAO e BROWN, 2004; ARPINO et al., 2008).

Os efeitos não-genômicos dos estrógenos, também conhecidos por MISS (Membrane-Initiated Steroid Signaling), não estão bem esclarecidos. Estudos mostram que 
esta atividade não genômica (Figura 6) é mediada pelo ER tradicional ou por suas pequenas variantes de splicing fixos à face interna da membrana citoplasmática. Esta fixação pode ocorrer através da ligação do receptor a proteínas de membrana como a caveolina-1, a flotilina-1 e a estriatina; ou através da sua associação a outros receptores de membrana como o IGFR, o EGFR e o ERBB2; ou ainda através da sua ligação à moléculas adaptadoras como a Shc, à tirosinas quinases como a Src e à proteínas G (HALL; COUSE; KORACH, 2001; CATO; NESTL; MINK, 2002; ARPINO et al., 2008).

Trabalhos recentes identificaram o domínio E do ER como a região que contém as informações necessárias para a localização e função do ER na membrana citoplasmática (RAZANDI et al., 2003a; PEDRAM et al., 2007). Em adição, outras moléculas relacionadas à sinalização dos fatores de crescimento, como a MNAR e a variante menor da MTA1, estão relacionadas à potencialização das ações do ER de membrana (KUMAR et al., 2002; WONG et al., 2002). De qualquer modo, a ligação do hormônio promove a ativação de tirosinas quinase e a consequente ativação de diversas vias de sinalização tais como as MAPK, PI3kinase/Akt, cAMP/PKA e ERBB2 (HALL; COUSE; KORACH, 2001; IVANOVA et al., 2002; KINOSHITA e CHEN, 2003; ARPINO et al., 2008). A influência não-genômica dos estrógenos na via da MAPK leva à proliferação e à diferenciação celular (WONG et al., 2002) e tem sido relacionada à ação protetora dos estrógenos nos sistemas vascular e esquelético (HALL; COUSE; KORACH, 2001). Kinoshita e Chen (2003) propuseram que, nas células MCF-7, a indução da atividade da aromatase é promovida por um mecanismo não-genômico através da interação entre o ER $\alpha$ e a via de sinalização EGF/MAPK. Além disso, tem sido sugerido que os SERMs, como o tamoxifen, podem se comportar como agonistas dos estrógenos quando ligados aos ERs de membrana (ARPINO et al., 2008).

Assim como o EGFR, o ERBB2 e o IGFR podem fosforilar o ER conduzindo à sua ativação, o ER de membrana pode ativar estes receptores através da ativação de Src, MMP 2 e 9, bem como da liberação do HB-EGF, um dos ligantes do EGFR. O HB-EGF, por sua vez, ativa cascatas de sinalização como a Ras/Mek/MAPK e PI3K/AKT as quais, por sua vez, fosforilam e ativam ER e seus coreguladores aumentando a atividade genômica do ER na transcrição gênica (RAZANDI et al., 2003b).

As funções do ER de membrana parecem não depender somente do ER, mas também de altos níveis dos receptores de fatores de crescimento e seus ligantes. Este modo de ação do ER deve, portanto, ser predominante nas células tumorais como, por exemplo, em 


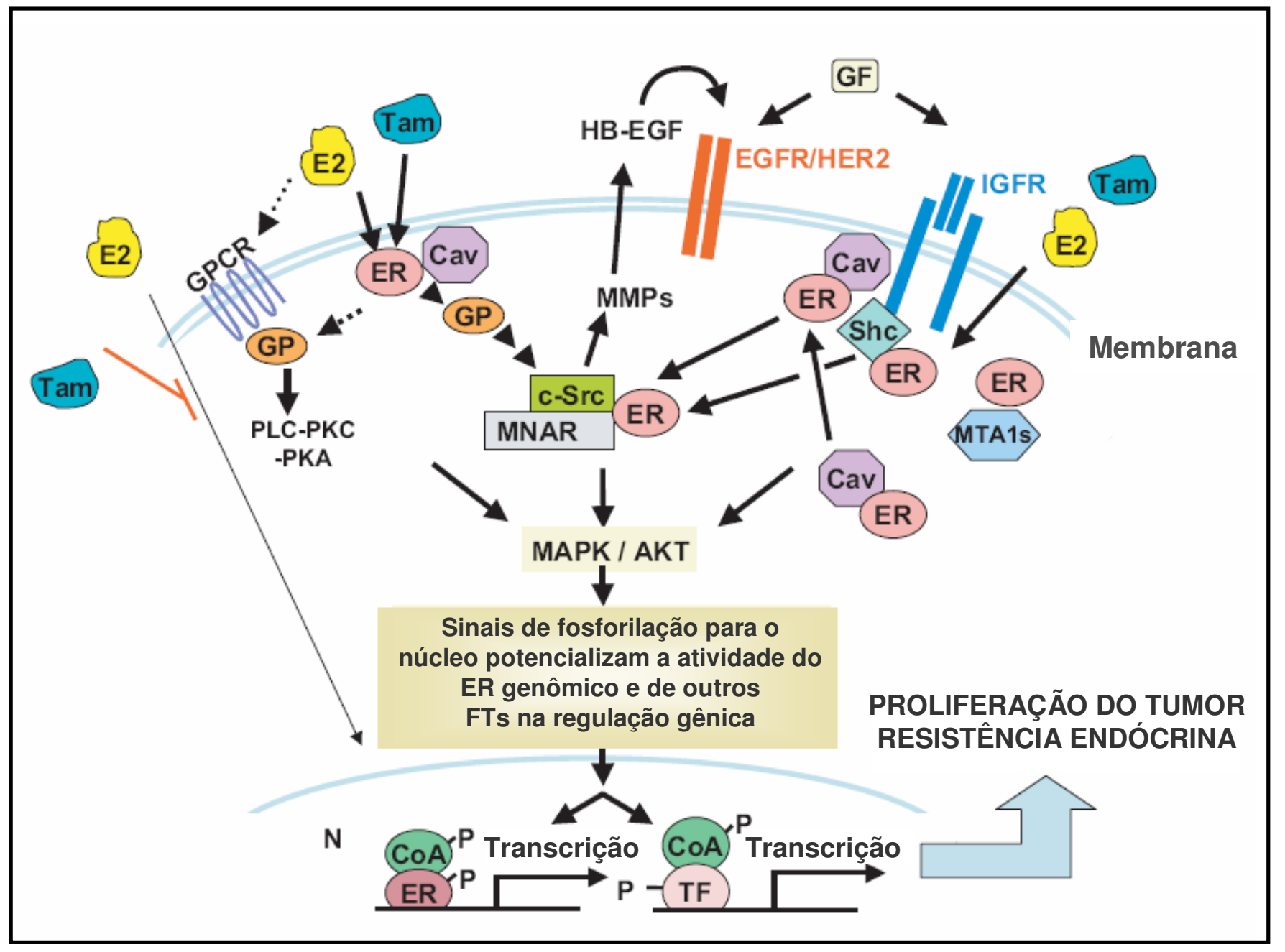

Figura 6. Integração da sinalização genômica e não genômica/rápida do ER (receptor de estrógeno) e sua interação com o receptor de fator de crescimento e as vias celulares mediadas por quinases na resistência endócrina. $\mathrm{O}$ estrógeno (E2) induz a atividade genômica do ER no núcleo $(\mathrm{N})$ o que resulta no aumento da transcrição de alguns genes que participam das vias dos fatores de crescimento. O Tamoxifen (Tam) antagoniza esta atividade. Entretanto, o E2 e o Tam, podem exercer suas funções através do ER de membrana e/ou citoplasma (sinalização conhecida por MISS). Esta indução, por sua vez, pode ativar os receptores tirosina-quinase (TKRs) para os fatores de crescimento (GF) - como o EGFR, HER2, IGFR - e quinases celulares como a c-Src. Moléculas sinalizadoras presentes no citoplasma, como a MTA1, podem aumentar a fração não-nuclear do ER. A interação entre o ER de membrana/citoplasma e os TKRs ativa as vias dos TKRs como a p42/44 MAPK e AKT. Outras atividades relacionadas ao MISS envolvem a ativação de receptores acoplados a proteínas G (GPCRs) os quais podem ativar c-Src e MMPs promovendo a liberação de HB-EGF. O HB-EGF pode estimular e ativar a via de sinalização EGFR/HER2. As quinases induzidas por TKR fosforilam $(\mathrm{P})$ o ER nuclear e seus co-ativadores (CoA) bem como outros fatores de transcrição (TF) potencializando a atividade genômica do ER que, por sua vez, resulta no aumento da expressão de genes relacionados às vias dos TKRs. Estes produtos gênicos podem promover o aumento da sinalização via GF-TKR completando assim o ciclo de cooperação entre as atividades genômica/não genômica do ER e sua interação com os receptores de fatores de crescimento e quinases celulares. Quando há um aumento de atividade das vias de sinalização TKR, como por exemplo, nos tumores com aumento de expressão de HER2, a atividade não genômica do ER pode ser tornar mais proeminente resultando na ativação de quinases que, por sua vez, podem conduzir à resistência endócrina através da modificação da atividade de diversos TFs e/ou da alteração da ação do Tam no ER nuclear. PKA, Proteína quinase A; GP, Proteína G.

FONTE: Modificado de Arpino, G. et al., 2008. 
tumores de mama que expressam altos níveis de receptores tirosina quinase como EGFR e ERBB2 (ARPINO et al., 2008).

\subsubsection{EGF e seus mecanismos de ação}

O EGF é um peptídeo de 6.045 Da que está envolvido na proliferação, sobrevivência e migração celulares, bem como nos processos de angiogênese e metástase (LICHTNER, 2003). Os efeitos biológicos deste fator de crescimento nos tecidos alvo são mediados pela sua ligação como o EGFR também chamado de ERBB1. O EGFR pertence à família de proteínas ERBB a qual é composta por quatro receptores (ERBB1-4) e 13 ligantes os quais, por sua vez, contêm três loops ligados à dissulfeto e um domínio EGF conservado (YARDEN e SLIWKOWSKI, 2001; CITRI e YARDEN, 2006).

Os ligantes da família ERBB incluem uma grande variedade de moléculas produzidas como proteínas transmembrânicas glicosiladas que são clivadas por proteases da superfície celular gerando os fatores de crescimento maduros que, por sua vez, irão controlar o crescimento e diferenciação celulares (COOPER, 2000; CITRI e YARDEN, 2006). Estes ligantes podem ser divididos em três grupos. O primeiro inclui o EGF, TGF- $\alpha$ e amphiregulina os quais ligam-se especificamente ao EGFR; o segundo grupo é composto pela betacelulina, HB-EGF e epiregulina os quais podem se ligar tanto ao EGFR quanto ao ERBB4. O terceiro grupo é composto pelas neuregulinas as quais, por sua vez, formam dois sub-grupos baseados na capacidade de ligação ao ERBB3 e ERBB4 (NRG1 e NRG2) ou somente ao ERBB4 (NRG3 e NRG4). Nenhum dos ligantes da família ERBB é capaz de se ligar ao ERBB2 (HYNES e LANE, 2005).

Os receptores ERBB são glicoproteínas transmembrânicas que apresentam um domínio extracelular composto por quatro sub-domínios (I-IV) na sua extremidade aminoterminal seguido por uma região transmembrânica e um pequeno domínio intracelular justamembrana que precede o domínio citoplasmático na região carboxi-terminal. Os subdomínios I e III apresentam os sítios de ligação aos fatores de crescimento enquanto os domínios II e IV estão relacionados ao processo de dimerização. O domínio citoplasmático, por sua vez, apresenta atividade tirosina quinase (HYNES e LANE, 2005; CITRI e YARDEN, 2006).

$\mathrm{Na}$ ausência do ligante, os domínios II e IV interagem de forma a manter os domínios de ligação ao ligante (I e III) distantes um do outro. Na presença do ligante, ocorre uma alteração conformacional que promove a aproximação dos domínios I e III com a 
consequente separação dos domínios II e IV permitindo assim a dimerização do domínio II dos receptores (Figura 7) (CITRI e YARDEN, 2006).

No receptor ERBB2 os domínios I e III interagem tão fortemente que impedem o acesso dos ligantes enquanto o domínio de dimerização apresenta-se constitutivamente estendido (CITRI e YARDEN, 2006). Além de apresentar o domínio de dimerização estendido o ERBB2 possui a capacidade de se ligar a uma grande variedade de proteínas que interagem com as fosfotirosinas; conferir ao heterodímero formado maior afinidade e menor especificidade aos ligantes; diminuir a velocidade de endocitose e promover a rápida reposição dos heterodímeros na superfície da célula. Por estes motivos, o ERBB2 é o receptor preferencial na formação de heterodímeros. O receptor ERBB3 não possui uma atividade quinase apropriada (PIETRAS, 2003; CITRI e YARDEN, 2006). Assim pode-se dizer que o EGFR e o ERBB4 atuam como homodímeros ou heterodímeros enquanto o ERBB2 e ERBB3 só realizam a transdução de sinais quando em heterodímeros.

A via tradicional de transdução de sinais via receptores da família ERBB envolve a ligação do fator de crescimento, com a subseqüente dimerização do receptor e a autofosforilação de seus resíduos de tirosina (Figura 8) (OSBORNE e SCHIFF, 2003; PIETRAS, 2003; CITRI e YARDEN, 2006). A ativação do EGFR, por exemplo, resulta no recrutamento de proteínas adaptadoras como o GRB2 e Shc que, por sua vez, recrutam Ras e ativam as vias de sinalização das MAPK. Outros alvos diretos do EGFR são a proteína Cbl, a qual regula negativamente a sinalização via EGFR, as STATs 3 e 5 e o PLC- $\gamma$. O EGFR não apresenta um sítio de ligação específico para a PI3K e, consequentemente, não ativa diretamente a via PI3K-AKT/PKB. Entretanto, por intermédio de Ras esta via pode ser ativada por EGFR (HYNES e LANE, 2005; CITRI e YARDEN, 2006). Dessa maneira, podese dizer que as vias de sinalização tradicionalmente ativadas pelo EGFR são a PLC- $\gamma$-Ca ${ }^{2+}$ dependente da calmodulina quinase $(\mathrm{CaMK}) / \mathrm{PKC}$, Ras-Raf-MAPK e PI-3K-AKT (PKB)GSK. (OSBORNE e SCHIFF, 2003; PIETRAS, 2003; LO; HSU; HUNG, 2006).

Um novo modo de atuação do EGFR ativado pelo EGF envolve sua translocação da superfície celular para o núcleo sem a participação de moléculas intermediárias (LO; HSU; HUNG, 2006). O mecanismo pelo qual o EGFR transloca para o núcleo e como o EGFR nuclear ativa a expressão gênica ainda não está bem determinada devido ao fato deste receptor não conter um domínio clássico de ligação ao DNA. Apesar disso, o EGFR especificamente reconhece o ATRS (AT-rich Response Sequence) na região promotora dos genes alvos, e sua região carboxi terminal apresenta forte atividade transcricional. Em adição, o domínio citoplasmático deste receptor contém um sinal de 


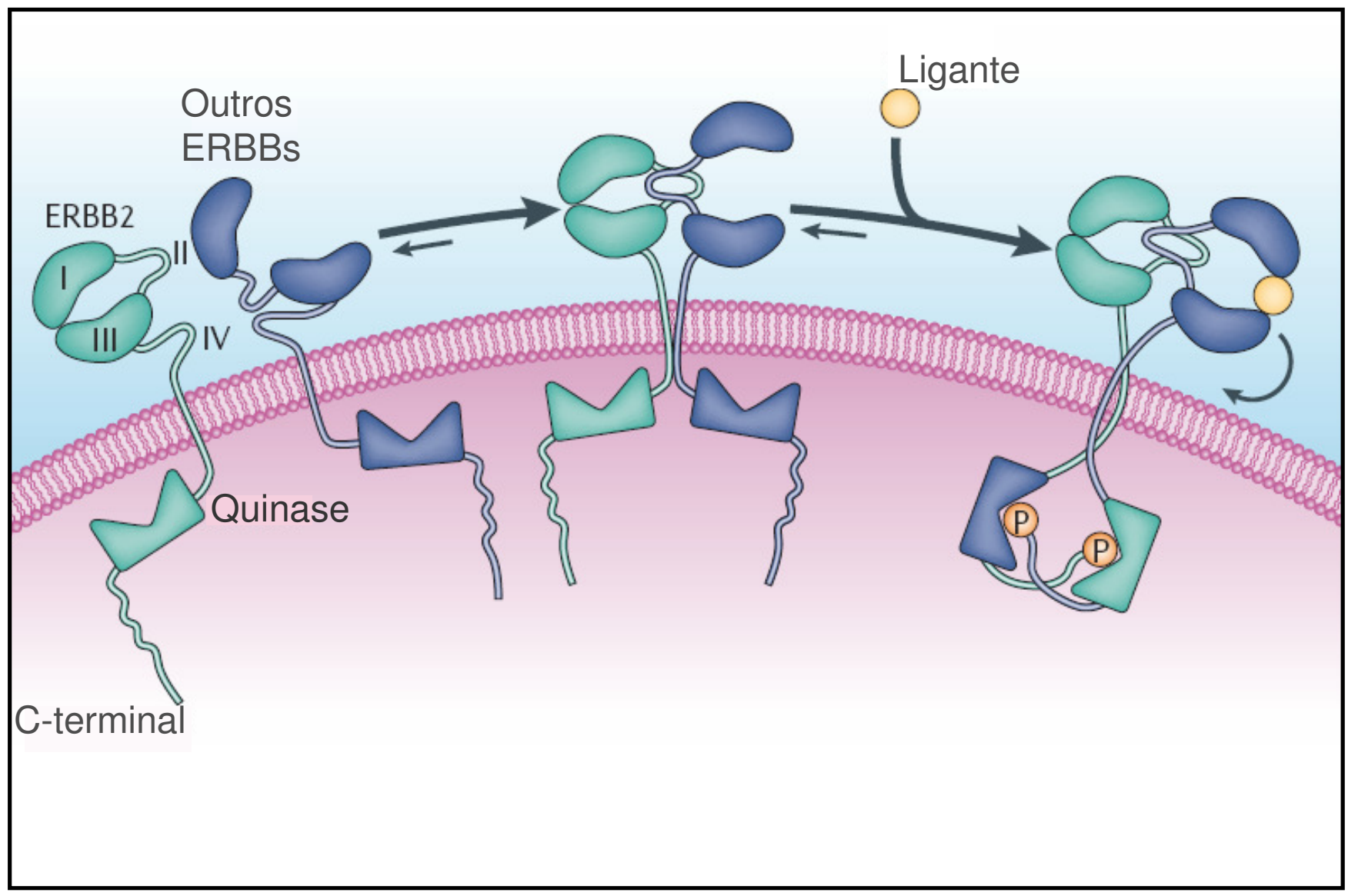

Figura 7. Base estrutural para a dimerização e ativação dos receptores ERBB. No estado monomérico, os domínios II e IV interagem promovendo a auto-inibição do receptor. Esta interação mantém os domínios de ligação ao ligante (I e III) distantes um do outro - impedindo que o ligante tenha acesso simultâneo a estes dois domínios - e, ao mesmo tempo, sequestra o sítio de dimerização composto pelos domínios II e IV. Na presença do ligante, ocorre uma alteração conformacional que promove a aproximação dos domínios I e III com a consequente separação dos domínios II e IV permitindo assim a dimerização do domínio II dos receptores. No receptor ERBB2 os domínios I e III interagem tão fortemente que impedem o acesso dos ligantes enquanto o domínio de dimerização apresenta-se constitutivamente estendido. Esta característica estrutural é uma das explicações para o fato do ERBB2 ser o receptor preferencial na formação de heterodímeros.

FONTE: Modificado de Citri, A. e Yarden,Y., 2006. 


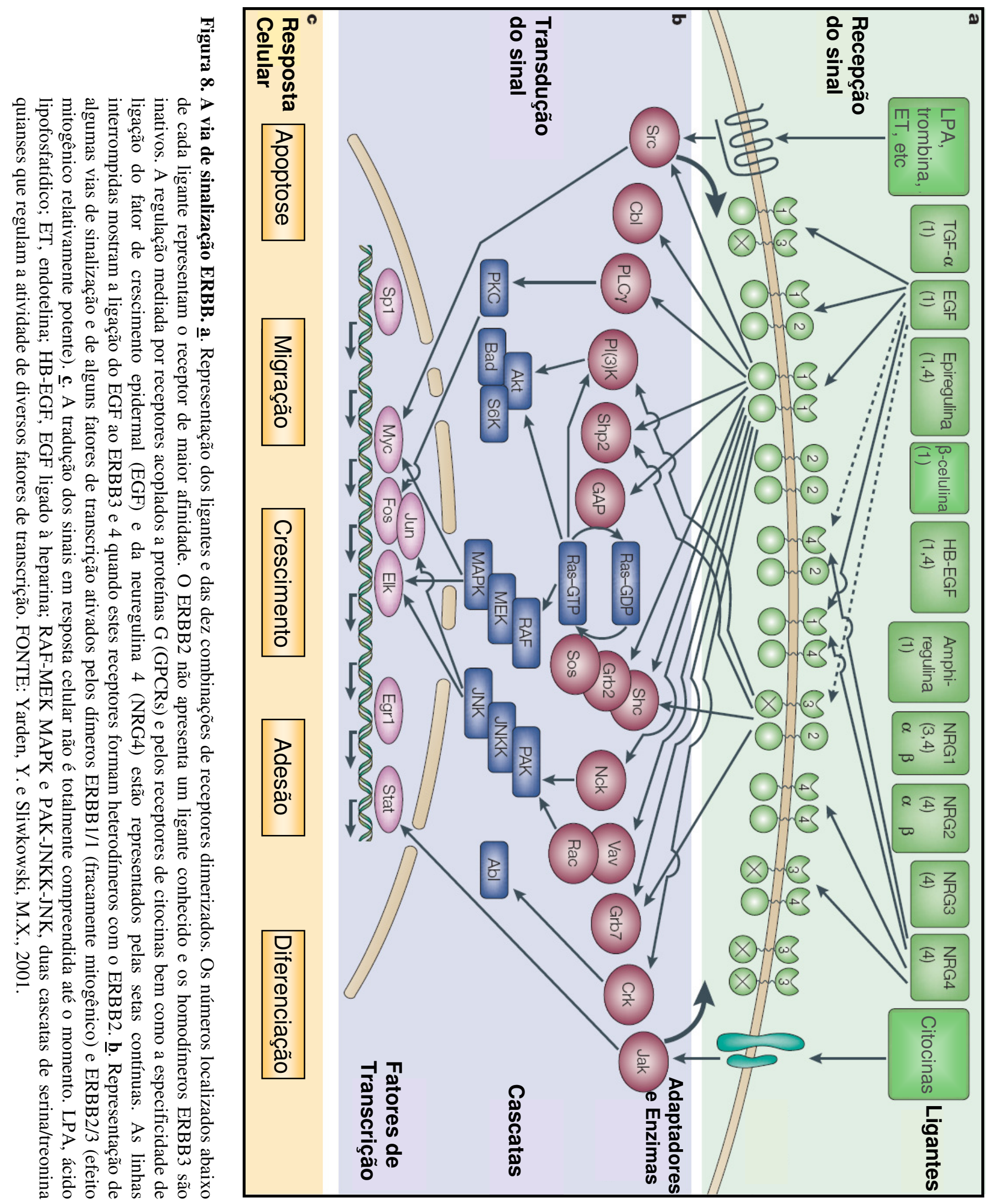


localização nuclear (LIN et al., 2001). Estudos mostram que o EGFR nuclear interage com e ativa os genes CCND1 e STAT3 sendo que o primeiro atua como regulador positivo da proliferação celular e o segundo promove o aumento da expressão de iNOS e óxido nítrico (LO; HSU; HUNG, 2006).

A implicação clínica da ação nuclear do EGFR precisa se melhor avaliada. Lo et al (2005) observaram, em 130 carcinomas de mama, uma correlação inversa entre a alta expressão de EGFR nuclear e sobrevida total das pacientes.

Outros receptores tirosina quinase, bem como seus ligantes, têm sido detectados no núcleo, tais como o NGFR, o FGFR, o receptor de insulina, o VEGFR2, o TGFBR1 e todos os outros membros da família ERBB (LO; HSU; HUNG, 2006).

\subsubsection{Interação entre as vias de sinalização do ER e do EGFR}

Como pode ser inferido a partir do exposto anteriormente (Figura 6), a interação entre as vias de sinalização do ER e do EGFR aumenta a capacidade de sinalização de ambas as vias. Consequentemente, esta interação pode ter importantes aplicações clínicas. Estudos mostram que o tamoxifen é menos efetivo no tratamento de tumores com alta expressão de ERBB2 e que este aumento de expressão está relacionado ao crescimento estimulado por esta droga caracterizando um mecanismo de resistência de novo. Não só o ERBB2 bem como os outros membros da família ERBB têm sido implicados na aquisição de resistência ao tamoxifen (ARPINO et al., 2008).

Curtis et al. (1996) mostraram que na ausência dos estrógenos, o EGF imita o efeito destes hormônios no sistema reprodutor de camundongos sendo que a supressão da expressão do $\mathrm{ER} \alpha$ nestes animais reprime o crescimento uterino mediado pelos estrógenos e pelo EGF. Em adição, Ignar-Trowbridge et al. (1993) mostraram que o EGF induz a ativação transcricional, ER-dependente, de uma construção contendo um ERE consenso em linhagens celulares de adenocarcinomas endometriais e ovarianos sendo que esta indução foi inibida pelo antiestrógeno ICI 164, 384 e pelo anticorpo anti-EGFR. O gene Cyr61, um fator próangiogênico, é positivamente regulado pelo E2 e pelo EGF na linhagem celular de câncer de mama MCF-7. A supressão da expressão deste gene, por sua vez, reduz significantemente a síntese de DNA dependente de EGF e de E2 e, consequentemente, a proliferação celular (SAMPATH; WINNEKER; ZHANG, 2001).

Stoica et al. (2000), mostraram que o tratamento das células MCF-7 (ERpositivas) com doses crescentes de EGF, na presença de soro fetal bovino, promove a 
diminuição da expressão do ER. A retirada dos estrógenos, por sua vez, aumenta a expressão do EGFR em linhagens celulares de câncer de mama ER-positivas enquanto a adição de E2 suprime a expressão deste receptor. Acredita-se que o aumento de expressão do EGFR após a retirada dos estrógenos seja um mecanismo de sobrevivência celular para evitar a apoptose induzida pela retirada dos estrógenos e esteja relacionado à aquisição de resistência à terapia hormonal (YARDEN; WILSON; CHRYSOGELOS, 2001).

Nos tumores de mama, existe uma relação inversa entre a expressão do EGFR e do ER (vanAGTHOVEN et al., 1994; PIETRAS, 2003). Além disso, tumores ERpositivos/EGFR-negativos apresentam um melhor prognóstico em relação aos ERnegativos/EGFR-positivos sendo que grande parte dos tumores EGFR-positivos é resistente à terapia endócrina e mais agressiva que os EGFR-negativos (STOICA et al., 2000).

Estudos clínicos mostram que o tratamento de tumores de mama ER-positivos e EGFR-positivos com agentes bloqueadores de ambos receptores apresenta um maior efeito antiproliferativo e pode ser a terapia de escolha para os tumores hormônio resistentes bem como para a prevenção da aquisição desta resistência (WITTERS et al., 1997; NICHOLSON et al., 2001). Assim, o melhor entendimento da interação entre as vias de sinalização do ER e do EGFR e a identificação de genes regulados por ambas as vias pode conduzir ao desenvolvimento de terapias cada vez mais eficazes e específicas para as pacientes com câncer de mama.

Na dissertação de mestrado, foi mostrada a ação oposta do E2 no controle da expressão de dois genes com diferentes funções: o $H N R P K$, sendo positivamente regulado pelo E2, e o PAWR, sendo negativamente regulado por este hormônio (BESSA, 2004).

O HNRPK (ribonucleoproteína heterogênea humana $\mathrm{K}, 9 \mathrm{q} 21$ ) é um dos membros da família das hnRNPs (ribonucleoproteínas heterogêneas nucleares) que, além de participar de maneira significativa na biogênese do RNAm (DREYFUSS et al., 1993) está envolvido na transdução de sinais, formando complexos com importantes moléculas transdutoras de sinal como a Src, Fyn e Lyn (SEUNINGEN et al., 1995; BOMZTYK et al., 1997) e atua como fator de transcrição (MICHELOTTI et al., 1996; LAU et al., 2000; OSTARECK-LEDERER et al., 2002; YANG et al., 2002) ativando ou reprimindo a transcrição de alguns genes relacionados ao controle do ciclo celular (MICHELOTTI et al., 1996; LAU et al., 2000). O aumento da expressão deste gene tem sido relacionado a situações de proliferação celular intensa (OSTROWSKI e BOMSZTYC, 2003). Em adição, Mandal et al. (2001) mostraram que a expressão deste gene é positivamente regulada pelos fatores de crescimento EGF e heregulina- $\beta 1$. 
O PAWR (PRKC, Apoptose, regulador do WT1, 12q21) é um gene próapoptótico altamente conservado durante a evolução dos vertebrados. A proteína codificada por este gene é encontrada no citoplasma e/ou no núcleo de diversos tipos celulares (GOSWAMI et al., 2006). Alterações na expressão do PAWR têm sido observadas em linhagens celulares de tumores de próstata (SELLS et al., 1994), em melanomas (LUCAS et al., 2001), em tumores renais (COOK et al., 1999) e em células hematopoiéticas (BRIEGER et al., 2004; KUKOC-ZWOJNOV et al., 2004). A diminuição na expressão de PAWR foi detectada em $40 \%$ dos carcinomas endometriais, sendo mais freqüente entre os tumores ERpositivos (MORENO-BUENO et al., 2007); em 60\% dos casos de tumores pancreáticos (AHMED et al., 2008) e em 59\% dos carcinomas de próstata (FERNANDEZ-MARCOS et al., 2009). Em adição, a deleção da região cromossômica 12q21, na qual este gene está localizado, é um evento freqüente nos tumores de estômago (KIMURA et al., 1998; SCHNEIDER et al., 2003).

Dados da literatura mostram que o $P A W R$ é induzido, exclusivamente, por estímulos apoptóticos tais como: retirada de fatores de crescimento, fator de necrose tumoral (TNF), radiação ionizante, elevação dos níveis intracelulares de cálcio (EL-GUENDY e RANGNEKAR, 2003), e que o aumento de sua expressão é suficiente para promover a apoptose em linhagens celulares de tumores de próstata e de mama hormônio-independentes, enquanto que nas linhagens normais e de tumores hormônio-dependentes a ação apoptótica do PAWR só ocorre na presença de um segundo sinal apoptótico (EL-GUENDY et al., 2003; GURUMURTHY e RANGNEKAR, 2004). Nas células de tumores de próstata andrógenodependentes, o aumento da expressão deste gene é observado após a castração, devido à elevação dos níveis intra-celulares de cálcio, e torna estas células hipersensíveis aos estímulos apoptóticos (RANGNEKAR, 1998; EL-GUENDY et al., 2003). Nas células de câncer de mama hormônio-reponsivas MCF-7, a retirada dos estrógenos, além de promover a inibição da proliferação celular, também promove a apoptose; entretanto, as vias bioquímicas envolvidas neste processo de morte celular nas células mamárias não estão bem esclarecidas (KYPRIANOU et al., 1991; ARMSTRONG et al, 1992).

Estudos mostram que a apoptose induzida pela expressão ectópica do PAWR envolve a ativação da via de sinalização do receptor de morte Fas e a inibição de NF- $\kappa B$, que por sua vez, inibe vias anti-apoptóticas permitindo assim a ação das caspases (CHAKRABORTY et al., 2001). É interessante observar que a função pró-apoptótica deste gene não é inibida pelo aumento de expressão de Bcl-2 ou Bcl-xL (CHAKRABORTY et al., 2001) mas sim pela interação com Akt-1. A interação, Akt-1/PAWR promove a fosforilação 
de PAWR impedindo sua translocação para o núcleo, a qual é um evento essencial para a apoptose mediada por este gene (GOSWAMI et al., 2005).

Ensaios realizados durante o desenvolvimento do trabalho de mestrado (BESSA, 2004) mostraram o aumento da expressão do PAWR tanto nas células MCF-7 (ER+) quanto nas células MDA-MB-231 (ER-) mantidas em soro livre de esteróides (soro tratado com carvão dextrana) indicando que, outras moléculas pequenas que são adsorvidas pelo carvão durante o tratamento do soro, tais como os fatores de crescimento, também modulem a expressão deste gene. Chan et al. (1999) mostraram que a retirada de fatores tróficos, os quais incluem alguns fatores de crescimento como o FGF, o IGF e o NGF, promovem o aumento de expressão do $P A W R$ em cultura de neurônios provenientes do hipocampo de rato. Os mesmos autores mostraram, também, que este aumento de expressão induzido pela retirada de fatores tróficos é bloqueado pelo tratamento das células com E2.

Nossos resultados, associados aos dados da literatura, indicam que o E2 e os fatores de crescimento exercem um importante papel no controle da expressão dos genes $P A W R$ e $H N R P K$ e sugerem a ocorrência de uma interação entre as vias de sinalização dos estrógenos e dos fatores de crescimento no controle da transcrição destes genes.

Outro gene de interesse do laboratório é o PHLDAl (domínio homólogo à pleckstrina, família A, membro 1, 12q15) também chamado de TDAG51. Estudos iniciais em hibridomas de células T de camundongos, mostraram que este gene está associado ao controle da expressão de Fas e ao controle da apoptose induzida por ativação dos receptores de células T (PARK et al., 1996). Posteriormente foi observado que, tanto a microinjeção quanto a expressão transiente de PHLDA1, promovia o aumento da morte celular independentemente da indução de Fas em cultura de células neuronais de hipocampo de rato (GOMES et al., 1999). Em adição, a proteína PHLDA1 apresenta seqüências repetitivas, tais como prolinaglutamina (PQ) e prolina-histidina $(\mathrm{PH})$, na sua região carboxi-terminal. Li; Plomann; Brundin (2003) observaram que proteínas contendo um grande número de repetições PQ podem atuar como ativadores transcricionais e mediar a apoptose em diversas doenças neurodegenerativas como a doença de Huntington.

Embora a exata função bioquímica e biológica do PHLDA1 seja desconhecida, estudos indicam que sua função está relacionada ao processo de apoptose e que sua expressão é induzida por diversos estímulos externos. Como exemplos de estudos podem ser citados Hossain et al. (2003) que, em cultura de células endoteliais vasculares, mostraram que a expressão deste gene é induzida por homocisteína, DTT e tunicamicina e que sua expressão transiente induz anoikis (apoptose induzida por perda de adesão). Toyoshima et al. (2004), 
por sua vez, mostraram que o tratamento com IGF-1 de células NIH3T3 apresentando aumento de expressão de IGF-1R induz a expressão de PHLDA1 e que a expressão de um siRNA contra o PHLDAl nestas células impede a ação do IGF-1 na reversão da apoptose induzida por ausência de soro (TOYOSHIMA et al., 2004).

Em relação ao processo tumorigênico, Neef et al. (2002) mostraram a diminuição da expressão deste gene nas células de melanoma metastático em relação às células de melanoma primário. Além disso, Nagai et al. (2007) mostraram que a diminuição da expressão do PHLDA1 é um evento freqüente no câncer de mama e está associada a um tumor de fenótipo mais agressivo podendo ser considerada um marcador de pior prognóstico para as pacientes. Neste mesmo estudo foi observado que pacientes PHLDA1-/ER- tinham o pior prognóstico. Entre as pacientes PHLDA1+, as que apresentavam ER- tinham um prognóstico mais favorável quando comparadas às pacientes ER+.

Tendo em vista os dados expostos acima, pode-se inferir que a expressão do gene $P H L D A 1$, assim como do $H N R P K$ e $P A W R$, também pode ser regulada por fatores de crescimento e estrógenos e ter um importante papel na tumorigênese.

O presente trabalho teve, portanto, o objetivo de verificar a possível interação entre as vias de sinalização dos estrógenos e dos fatores de crescimento no controle da transcrição dos genes $H N R P K, P A W R$ e PHLDA1. Para atingir este fim, foram utilizadas as linhagens celulares de câncer de mama MCF-7 (ER-positiva) e MDA-MB-231 (ER-negativa) tratadas com 17ß-estradiol (E2), tamoxifen, ICI, 182,780 e EGF. As análises de expressão gênica foram realizadas por Real Time PCR enquanto as análises de expressão protéica foram conduzidas por Western Blot. 


\section{OBJETIVOS}

\subsection{Objetivo global}

Investigar a ocorrência de interação entre as vias de sinalização dos estrógenos e dos fatores de crescimento no controle da expressão dos genes HNRPK, PAWR e PHLDAl.

\subsection{Objetivos específicos}

- Verificar o efeito do E2, ICI 182,780 e EGF, isoladamente e em combinação, no controle da expressão dos genes HNRPK, PAWR e PHLDAl nas linhagens celulares de câncer de mama MCF-7 e MDA-MB-231;

- Verificar o efeito do E2, ICI 182,780 e EGF, isoladamente e em combinação, no controle da expressão dos genes $H N R P K, P A W R$ e PHLDAl na linhagem celular de câncer de mama MCF-7 após a supressão da expressão do ER pela técnica de siRNA. 


\section{MATERIAL E MÉTODOS}

\subsection{Material Biológico}

As linhagens celulares de câncer de mama MCF-7 (ER-positiva, SOULE et al., 1973) e MDA-MB-231 (ER-negativa, CAILLEAU et al., 1974) foram adquiridas da ATCC (American Type Culture Collection) e cultivadas em meio RPMI 1640 (Sigma Chemical Corporation, St. Louis, EUA) contendo antibiótico-antimicótico (Gibco, Gaithersburg, EUA) e suplementado com $10 \%$ de soro fetal bovino (Gibco, Gaithersburg, EUA). As concentrações de antibiótico-antimicótico utilizadas foram: 100,0 U/ml de penicilina, 100,0 $\mu \mathrm{g} / \mathrm{ml}$ de estreptomicina e $0,25 \mu \mathrm{g} / \mathrm{ml}$ de fungizona As células foram mantidas em estufa (Thermo Electron Corporation, Marietta, EUA) a $37{ }^{\circ} \mathrm{C}$ sob atmosfera de $5 \%$ de $\mathrm{CO}_{2}$. Ao atingirem a confluência, as células foram sub-cultivadas utilizando-se a tripsina-EDTA (Gibco, Gaithersburg, EUA) para separação das células. Uma parte destas células foi transferida para novos frascos de cultura a fim de ampliar a cultura e a outra parte foi ressuspensa em 1,0 ml de solução de congelamento - $50 \%$ de soro fetal bovino, $40 \%$ de RPMI 1640 e $10 \%$ de DMSO (Sigma Chemical Corporation, St. Louis, EUA) - e conservada em nitrogênio líquido para manutenção de células viáveis em estoque.

Para a realização dos experimentos, as células foram cultivadas em meio RPMI 1640 sem vermelho de fenol (Sigma Chemical Corporation, St. Louis, EUA) - pois o vermelho de fenol é um indicador de $\mathrm{pH}$ que possui fraca atividade esteroídica suplementado com $5 \%$ de soro fetal bovino livre de esteróides (tratamento com carvão dextrana; ARMELIN, 1978) por pelo menos 48 horas a fim de garantir que os resultados obtidos decorreram da ação das substâncias que foram adicionadas ao meio de cultura. Ao atingirem a sub-confluência, as células foram submetidas aos tratamentos com $10^{-8} \mathrm{M}$ de $17 \beta$ estradiol (Sigma Chemical Corporation, St. Louis, EUA), $10^{-6} \mathrm{M}$ de tamoxifen, $10^{-6} \mathrm{M}$ de ICI 182,780 (Tocris, Ellisville, EUA), 50,0 ng/ml de EGF (Sigma Chemical Corporation, St. Louis, EUA), 5,0 $\mu$ M LY 294002 (Inibidor da via PI3K - Sigma Chemical Corporation, St. Louis, EUA), 5,0 $\mu \mathrm{M}$ SB 202190 (Inibidor da via p38 $\alpha / \beta$ MAPK - Sigma Chemical Corporation, St. Louis, EUA) e 5,0 $\mu$ M PD 98059 (Inibidor da via ERK1/2, Sigma Chemical Corporation, St. Louis, EUA) por diferentes intervalos de tempo. Quando utilizados em combinação com outras substâncias, o ICI 182,780, o LY 294002, o SB 202190 e o PD 98059 foram adicionados 1 hora antes ao meio de cultura. 


\subsection{Tratamento do Soro com Carvão Dextrana}

A função do soro fetal na cultura de células é fornecer reguladores de natureza hormonal, tais como fatores de crescimento e hormônios clássicos. Para se obter um soro pobre em esteróides, Armelin (1978) desenvolveu uma técnica capaz de extrair, utilizando carvão ativo, os esteróides do soro sem inativar os demais componentes. Entretanto, este processo não é específico, pois outras substâncias, tais como os fatores de crescimento, são adsorvidas pelo carvão.

Para o tratamento de 100,0 $\mathrm{ml}$ de soro deve-se inicialmente, adicionar 1,25 g de carvão dextrana (Sigma Chemical Corporation, St. Louis, EUA) a 50,0 ml de PBS-A $\left(8,2 \mathrm{~g} / 1 \mathrm{NaCl} ; 0,2 \mathrm{~g} / \mathrm{l} \mathrm{KCl} ; 1,15 \mathrm{~g} / 1 \mathrm{Na}_{2} \mathrm{PO}_{4} .2 \mathrm{H}_{2} \mathrm{O} ; 0,2 \mathrm{~g} / 1 \mathrm{KH}_{2} \mathrm{PO}_{4}\right)$, centrifugar essa mistura a 10.000 r.p.m. por 20 minutos a $4{ }^{\circ} \mathrm{C}$ e desprezar o sobrenadante. A seguir, o soro é misturado ao carvão e mantido sob agitação a $4{ }^{\circ} \mathrm{C}$ por 1 hora. Após este período, a mistura é centrifugada a 10.000 r.p.m. por 25 minutos a $4{ }^{\circ} \mathrm{C}$. O sobrenadante resultante é, então, filtrado uma vez em papel de filtro 3,0 $\mu \mathrm{m}$ (Inlab, Brasil) e três vezes em membrana de nitrocelulose 0,22 $\mu \mathrm{m}$ (Millipore Corporation, Massachussetts, EUA) para esterilização. Os reagentes utilizados na solução de PBS-A, com exceção do $\mathrm{NaCl}$ (Sigma Chemical Corporation, St. Louis, EUA), foram obtidos da Merck, Darmstadt, Alemanha.

Nosso laboratório utiliza a sigla ST (Soro Tratado) para designar o soro submetido ao tratamento com carvão dextrana e a sigla SN (Soro Normal) para designar o soro sem tratamento.

Para o controle da eficiência da retirada de esteróides do soro uma alíquota do soro tratado e uma alíquota do soro normal foram enviadas ao Laboratório de Hormônios e Genética Molecular (Disciplina de Endocrinologia da Divisão de Laboratório Central do Hospital das Clínicas da Faculdade de Medicina da Universidade de São Paulo) para a realização da dosagem do E2 presente nestas amostras. Esta quantificação, realizada pelo método fluorimétrico, revelou que a concentração de E2 presente no soro tratado era indetectável. 


\subsection{RNAi - RNA de interferência}

\subsubsection{Supressão da expressão do gene ER $\alpha$ por siRNA inserido em vetor de expressão}

Para garantir que os níveis intracelulares de siRNA seriam mantidos por maiores intervalos de tempo, utilizou-se siRNAs para o ER $\alpha$ e para controle inseridos em vetores de expressão. Neste estudo, as células MCF-7 foram transfectadas com TransSilent ${ }^{\mathrm{TM}}$ siRNAs vector mixes adquiridos da Panomics (Redwood City, EUA). O vetor utilizado neste kit da Panomics, o pU6+27 (Figura 9), confere resistência a neomicina para as células transfectadas. O reagente de transfecção utilizado foi a TurboFectin 8.0 (Origene Tech, Maryland, EUA).

Para a realização deste experimento, as células MCF-7 foram transferidas para placas de seis poços $\left(3.10^{5}\right.$ células/poço) e cultivadas em meio RPMI 1640 contendo antibiótico/antimicótico e suplementado com $10 \%$ de soro fetal bovino. Ao atingirem $70 \%$ de confluência iniciou-se o processo de transfecção segundo as recomendações do fabricante. Foram testadas diferentes proporções de DNA $(\mu \mathrm{g})$ : TurboFectin $8.0(\mu \mathrm{l})$. Para o TranSilent sh RNA Vector Mix utilizou-se as proporções 1,0 $\mu \mathrm{g}: 3,0 \mu \mathrm{l} ; 1,0 \mu \mathrm{g}: 6,0 \mu \mathrm{l}$ e 2,5 $\mu \mathrm{g}$ : 6,0 $\mu$ l. Para o TranSilent Control Vector foi utilizada somente a proporção 1,0 $\mu \mathrm{g}: 3,0 \mu \mathrm{l}$. Após a transfecção, as células foram incubadas a $37^{\circ} \mathrm{C}$ por 24 horas para então dar início ao processo de seleção das células transfectadas adicionando-se ao meio de cultura $3.000 \mu \mathrm{g} / \mathrm{ml}$, de geneticina (um análogo da neomicina, Gibco, Grand Island, EUA) até que todas as células do poço não transfectado morressem, e $800 \mu \mathrm{g} / \mathrm{ml}$ para manutenção.

3.3.1.1 Transformação das bactérias competentes da linhagem XL1-Blue com os vetores de expressão contendo o siRNA para o gene ER $\alpha$ e o siRNA controle

Com o objetivo de imortalizar o TranSilent sh RNA Vector Mix e o TranSilent Control Vector foi realizada a transformação das XL1-Blue Competent Cells (Stratagene, Cedar Creek, EUA) com estes vetores. As bactérias foram transformadas por choque térmico da seguinte maneira: $0,1 \mu \mathrm{g}$ do vetor contendo o siRNA para o gene $E R \alpha$ bem como $0,1 \mu \mathrm{g}$ do vetor controle foram misturados a 20,0 $\mathrm{mM}$ de $\mathrm{MgCl}_{2}$ (Merck, Darmstadt, Alemanha) e 10,0 $\mathrm{mM}$ de $\mathrm{CaCl}_{2}$ (Merck, Darmstadt, Alemanha). A seguir, adicionou-se 50,0 $\mu \mathrm{l}$ da 


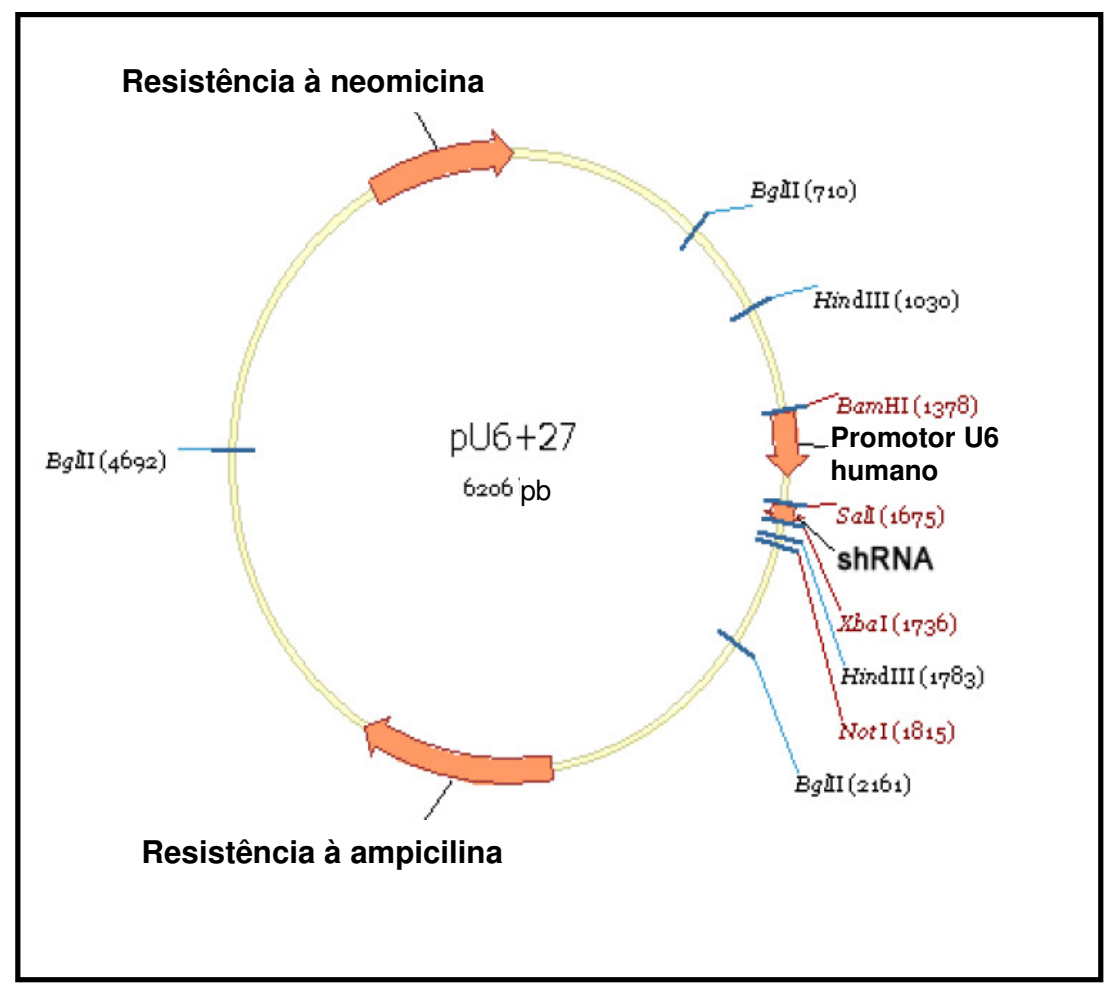

Figura 9. Mapa do vetor pU6+27 representando os diversos sítios de restrição nele presentes e suas respectivas posições.

FONTE: Modificado de TranSilent ${ }^{\mathrm{TM}}$ sh Vector Mix, Product User Manual, 2005. 
suspensão de células competentes e esta mistura foi incubada por 20 minutos no gelo e por 10 minutos a $21^{\circ} \mathrm{C}$.

Acrescentou-se, então, 1,0 ml de meio LB (5,0 g/l extrato de levedura; 10,0 g/l tiptona-peptona; $10,0 \mathrm{~g} / \mathrm{l} \mathrm{NaCl}$ ) e realizou-se uma nova incubação por 1 hora, a $37{ }^{\circ} \mathrm{C}$ sob agitação de 200 r.p.m. para multiplicação das células transformadas. Cem microlitros desta suspensão foram plaqueados em meio LB + Agar $(15,0 \mathrm{~g} / \mathrm{l})$ contendo 50,0 $\mu \mathrm{g} / \mathrm{ml}$ de ampicilina (Sigma Chemical Corporation, St. Louis, EUA) e incubadas em estufa (Fanem, São Paulo, Brasil) a $37{ }^{\circ} \mathrm{C}$ por aproximadamente 16 horas. Um clone isolado foi então repicado em 3,0 $\mathrm{ml}$ de meio $\mathrm{LB}$ contendo $50,0 \mu \mathrm{g} / \mathrm{ml}$ de ampicilina e incubado por, aproximadamente 4 horas a $37^{\circ} \mathrm{C}$ e 200 r.p.m. Cinqüenta microlitros deste pré-inóculo foram incubados em 25,0 $\mathrm{ml}$ de meio LB contendo $50,0 \mu \mathrm{g} / \mathrm{ml}$ de ampicilina por 16 horas a $37^{\circ} \mathrm{C}$ e 200 r.p.m. A seguir, $1,0 \mathrm{ml}$ desta cultura foi aliquotada em tubo de rosca ao qual adicionou-se $20 \%$ de glicerol para congelamento a $-70{ }^{\circ} \mathrm{C}$. O restante da cultura foi utilizado para purificação do inserto utilizando-se o Qiagen Plasmid Midi Kit 25 (Qiagen, Valencia, EUA) seguindo as recomendações do fabricante. Os vetores extraídos foram ressuspensos em $\mathrm{H}_{2} \mathrm{O}$ DNase/RNase free (Invitrogen, Grand Island, EUA).

Para confirmar se o inserto obtido era realmente o TranSilent sh RNA Vector Mix e o TranSilent Control Vector, 1,0 $\mu \mathrm{g}$ de cada inserto foi digerido com as enzimas Bgl II e Hind III ambas da Gibco (Gaithersburg, EUA) e com sítios de restrição presentes no TranSilent sh RNA Vector Mix e no TranSilent Control Vector (Figura 9). A digestão destes vetores com a enzima $B g l$ II resulta em uma banda de $1.451 \mathrm{pb}$ e uma de 4.755 pb enquanto a digestão com a Hind III gera uma banda de 753 pb e outra de 5.453 pb. As análises dos digestos foram feitas em gel de agarose $1 \%$ contendo $0,8 \mu \mathrm{g} / \mathrm{ml}$ de brometo de etídeo. Neste gel foram aplicados $10,0 \mu \mathrm{l}$ do digesto diluídos em 3,0 $\mu$ l do tampão type II (0,25 \% azul de bromofenol, 0,25 \% xileno cianol, $15 \%$ ficoll 400) e utilizou-se o $1 \mathrm{~kb}$ (Invitrogen, Califórnia, EUA) como marcador de peso molecular. A corrida eletroforética foi realizada em tampão TBE (Tris 0,09 M; ácido bórico 0,09 M e EDTA 0,002 M) a 5,5 V/cm.

\subsubsection{Sensibilização das XL1-Blue Competent Cells para o processo de transformação}

Antes de serem utilizadas no processo de transformação, as XL1-Blue Competent Cells foram sensibilizadas por $\mathrm{Ca}^{2+}$ de acordo com o seguinte protocolo: um inóculo de XL1-Blue Competent Cells foi preparado em meio LB+Agar contendo 40,0 $\mu \mathrm{g} / \mathrm{ml}$ 
de tetraciclina e incubado a $37{ }^{\circ} \mathrm{C}$ por 16 horas. Posteriormente, um clone isolado foi inoculado em 5,0 ml de meio LB contendo $40,0 \mu \mathrm{g} / \mathrm{ml}$ de tetraciclina e incubado a $37{ }^{\circ} \mathrm{C}$ sob agitação de 150 r.p.m. por 12-15 horas. Passado o período de incubação, este inóculo foi subcultivado em 500,0 $\mathrm{ml}$ de meio $\mathrm{LB}$ contendo $40,0 \mu \mathrm{g} / \mathrm{ml}$ de tetraciclina e incubado a $37{ }^{\circ} \mathrm{C}$ sob agitação de 150 r.p.m. até atingir uma $\mathrm{DO}_{600}$ 0,3 (aproximadamente $3 \mathrm{~h}-4 \mathrm{~h}$ de incubação). Esta cultura foi, então, dividida em frascos de $50,0 \mathrm{ml}$ e incubada no gelo por 5 minutos seguida por uma centrifugação de 10 minutos a 3000 r.p.m. e $4{ }^{\circ} \mathrm{C}$. O sobrenadante foi desprezado e cada pellet foi ressuspenso em 20,0 ml de tampão $\mathrm{Ca}^{2+} /$ glicerol (60 mM $\mathrm{CaCl}_{2} ; 10 \mathrm{mM}$ Pipes; $15 \%$ glicerol) gelado. Esta última etapa foi repetida por 3 vezes. Após a última centrifugação o sobrenadante foi desprezado e os pellets foram ressuspensos no volume adequado de tampão $\mathrm{Ca}^{2+} /$ glicerol gelado. A suspensão de células foi aliquotada em tubos de rosca de $1,5 \mathrm{ml}$ e imediatamente congelada em gelo seco. As alíquotas congeladas foram então estocadas a $-70{ }^{\circ} \mathrm{C}$.

\subsubsection{Supressão da expressão do gene ERa utilizando siRNA transiente}

Para a realização deste ensaio, as células foram cultivadas em placas de seis poços e ao atingirem $50 \%$ de confluência iniciou-se o processo de transfecção utilizando-se 50,0 nM do siRNA ER $\alpha$ (Dharmacon, Chicago, EUA) ou do siRNA controle (Dharmacon, Chicago, EUA) e o reagente de transfecção Lipofectamine ${ }^{\mathrm{TM}} 2000$ (Invitrogen, Grand Island, EUA) segundo as recomendações do fabricante. Após o processo de transfecção, as células foram incubadas a $37^{\circ} \mathrm{C}$ por 5 horas. Passado o período de incubação procedeu-se a troca do meio para meio RPMI 1640 contendo antibiótico/antimicótico e suplementado com $10 \%$ de soro fetal bovino. As células foram, então, incubadas por mais 19 horas a $37^{\circ} \mathrm{C}$ e a seguir procedeu-se a extração do RNA e da proteína.

Outro ensaio utilizando o siRNA transiente foi realizado com o objetivo de determinar a duração do silenciamento do gene $E R \alpha$ bem como de verificar se há diferença na expressão dos genes $P A W R$ e $P H L D A 1$ após o silenciamento do ER $\alpha$ entre as células mantidas em SN e ST. Para tanto, antes de iniciar a transfecção, o meio de cultura das células foi trocado para meio completo contendo $5 \%$ de SN ou $5 \%$ de ST. Após a transfecção, as células foram incubadas a $37^{\circ} \mathrm{C}$ por $24 \mathrm{~h}, 48 \mathrm{~h}, 72 \mathrm{~h}$ e $96 \mathrm{~h}$ sendo que após $24 \mathrm{~h}$ procedeu-se a extração do RNA e da proteína dos pontos SN-24 h e ST-24 h e a troca do meio de cultura dos demais poços. O RNA total e os extratos protéicos deste experimento foram extraídos utilizando-se o Paris ${ }^{\mathrm{TM}}$ Kit (Ambion, Austin, EUA) seguindo as recomendações do fabricante. 
Os reagentes, para os quais a procedência não foi informada, foram obtidos da Merck, Darmstadt, Alemanha ( $\mathrm{NaCl}$, azul de bromofenol, pipes); Difco, Sparks, EUA (extrato de levedura, triptona/peptona, agar); Sigma Chemical Corporation, St. Louis, EUA (brometo de etídeo, xileno cianol, tetraciclina); Amershan Biosciences, Nova Jersey, EUA (ficoll 400, Tris base); Ivitrogen, Grand Island, EUA (agarose); Gibco, Gaithersburg, EUA (EDTA); USB, Cleveland, EUA (glicerol) e Amresco, Solon, EUA (ácido bórico).

\subsection{Extração do RNA Total de Células em Cultura}

A monocamada de células aderida ao frasco de cultura foi lavada três vezes com solução de PBS-A. Após a última lavagem a solução de PBS-A foi totalmente retirada e adicionou-se o volume adequado de solução D (isotiocianato de guanidina 4,0 M; citrato de sódio 25,0 mM pH 7,0; sarcosil 0,5 \% e 2-mercaptoetanol 0,1 M) gelada. Após a lise total das células a solução foi transferida para um tubo adequado e o RNA total foi extraído pelo método de Chomczynski e Sacchi (1987). Este método se baseia na capacidade do RNA manter-se hidrossolúvel ao ser isolado utilizando-se uma solução contendo isotiocianato de guanidina 4,0 M (um potente agente desnaturante e inibidor de ribonuclease), $\mathrm{pH}$ 4,0, na presença do clorofórmio e do fenol. Sob estas condições, grande parte das proteínas e pequenos fragmentos de DNA (50 bases a $10 \mathrm{~kb}$ ) permanecem na fase orgânica, enquanto os maiores fragmentos de DNA e algumas proteínas ficam na intérfase (KRIEG, 1996).

Adicionou-se 0,2 M de acetato de sódio, $\mathrm{pH}$ 4,0; fenol saturado $\mathrm{pH}$ 5,0-6,0 no mesmo volume de solução D utilizada e clorofórmio-álcool isoamílico (49:1) na proporção de $25 \%$ do volume de solução D sendo que após a adição de cada solução, a mistura foi homogeneizada por inversão. A suspensão final foi agitada vigorosamente por 10 segundos e deixada em banho de gelo por 15 minutos. Após este período, as amostras foram centrifugadas por 20 minutos a 10.000 r.p.m. e a $4{ }^{\circ} \mathrm{C}$. A fase aquosa foi transferida para um novo tubo e precipitada a $-20^{\circ} \mathrm{C}$ em 1,0 volume de isopropanol por 1 hora ou overnight. A seguir, o material foi centrifugado a 10.000 r.p.m. por 20 minutos a $4{ }^{\circ} \mathrm{C}$, o sobrenadante foi desprezado e o precipitado resultante foi e dissolvido em $0,15 \mathrm{ml}$ de solução $\mathrm{D}$, transferido para tubos cônicos de $1,5 \mathrm{ml}$ e precipitado overnight a $-20{ }^{\circ} \mathrm{C}$ com $0,15 \mathrm{ml}$ de isopropanol. Após este período as amostras foram centrifugadas a 10.000 r.p.m. por 20 minutos a $4{ }^{\circ} \mathrm{C}$, o sobrenadante foi desprezado e o precipitado resultante foi lavado com $0,15 \mathrm{ml}$ de etanol $75 \%$ e centrifugado a 10.000 r.p.m. por 10 minutos a $4{ }^{\circ} \mathrm{C}$. Após a centrifugação o sobrenadante foi 
desprezado e o precipitado foi seco a temperatura ambiente por, aproximadamente, 15 minutos e ressuspenso em $\mathrm{H}_{2} \mathrm{O}$ DNase/RNase-free (Ivitrogen, Grand Island, EUA).

A concentração do RNA total extraído foi determinada por leitura espectrofotométrica a 260/280 nm no geneQuant pro (Amersham Biosciences, Cambridge, Inglaterra) e a qualidade do material foi analisada através de eletroforese em gel de agarose $1 \%$ contendo formaldeído. As amostras de RNA para eletroforese foram preparadas da seguinte maneira: 1,0 $\mu \mathrm{l}$ da amostra foi adicionada a 3,0 $\mu \mathrm{lde} \mathrm{H}_{2} \mathrm{O}$ DNase/RNase-free e a 4,0 $\mu \mathrm{l}$ de tampão de aplicação (750,0 $\mu$ l formamida deionizada; $150,0 \mu \mathrm{l}$ MOPS $10,0 \mathrm{X}$; 240,0 $\mu \mathrm{l}$ formaldeído; 100,0 $\mu \mathrm{l} \mathrm{H}_{2} \mathrm{O}$ DNase/RNase-free; 100,0 $\mu$ l glicerol; 80,0 $\mu \mathrm{l}$ azul de bromofenol $5 \%$ ). A mistura foi incubada por 15 minutos a $65{ }^{\circ} \mathrm{C}$. A seguir, adicionou-se $1,0 \mu \mathrm{l}$ de brometo de etídeo $1,0 \mathrm{mg} / \mathrm{ml}$ e o volume total foi aplicado no gel. A corrida eletroforética foi realizada em tampão MOPS (MOPS 0,02 M; acetato de sódio 5,0 mM; EDTA $0,1 \mathrm{mM}$; pH 7,0) a $4 \mathrm{~V} / \mathrm{cm}$.

Os reagentes utilizados neste procedimento, para os quais a procedência não foi informada nos itens anteriores, foram obtidos da Fisher Scientific International Inc., Hampton, EUA (Sarcosil); Invitrogen Life Technologies, California, EUA (isotiocianato de guanidina); Gibco, Gaithersburg, EUA (citrato de sódio); Merck, Darmstadt, Alemanha (acetato de sódio anidro, álcool isoamílico, clorofórmio, isopropanol, etanol absoluto, fenol, formaladeído 37\%) e Sigma Chemical Corporation, St. Louis, EUA (2-mercaptoetanol, formamida deionizada, MOPS).

\subsubsection{Tratamento do RNA com DNase I}

Após a verificação da sua integridade e concentração, o RNA total extraído foi submetido ao tratamento com DNase I (Promega, Madison, EUA) a fim de se eliminar as possíveis contaminações com DNA. A reação foi preparada segundo as instruções do fabricante e, passado o período de incubação, o RNA foi precipitado overnight a $-20{ }^{\circ} \mathrm{C}$ em 0,2 M de acetato de sódio pH 4,0-4,6 e 2,5 volumes de etanol absoluto. Após este período, o RNA foi centrifugado a 10.000 r.p.m. por 20 minutos a $4{ }^{\circ} \mathrm{C}$ e o sobrenadante foi desprezado. Adicionou-se, então, 4,0 volumes de etanol $75 \%$ para lavagem do precipitado e, em seguida, foi feita nova centrifugação a 10.000 r.p.m. por 10 minutos a $4{ }^{\circ} \mathrm{C}$. O sobrenadante foi novamente desprezado e o precipitado foi seco a temperatura ambiente por, aproximadamente, 15 minutos e ressupenso no volume desejado de $\mathrm{H}_{2} \mathrm{O}$ DNase/RNase-free 
(SAMBROOK; FRITSCH; MANIATIS, 1989; KRIEG, 1996). Vide procedência dos reagentes utilizados no item 3.3 .

\subsubsection{Síntese do cDNA}

A síntese do cDNA foi realizada utilizando-se o High Capacity cDNA Archive Kit (Applied Biosystems, Warrington, UK) seguindo as instruções do fabricante e acrescentando, em cada reação, 1,0 U/ $\mu \mathrm{l}$ de RNaseOUT Ribonuclease Inhibitor (Invitrogen Life Technologies, Califórnia, EUA).

Para a verificação da qualidade e da massa, o cDNA sintetizado foi amplificado utilizando-se oligonucleotídeos para os genes $\beta$-2-microglobulina (TAPLIN et al., 1995) e GAPDH os quais são expressos constitutivamente. As reações foram realizadas em um volume total de 25,0 $\mu$ l utilizando-se 2,5 $\mu \mathrm{l}$ do cDNA diluído 1:10; a concentração adequada de cada par de oligonucleotídeos ( $\beta$-2-microglobulina: 0,08 $\mu \mathrm{M}$ de cada oligonucleotídeo e GAPDH: 0,16 $\mu \mathrm{M}$ de cada oligonucleotídeo); 125,0 $\mu \mathrm{M}$ de dNTPs (Amersham Biosciences, Nova Jersey, EUA); 50,0 mM KCl; 10,0 mM Tris $\mathrm{HCl} \mathrm{pH} 8,3$; $0,1 \mathrm{mg} / \mathrm{ml}$ de gelatina; $1,5 \mathrm{mM} \mathrm{MgCl}_{2}$ e $0,75 \mathrm{U}$ de Taq DNA polimerase (Invitrogen Life Technologies, Califórnia, EUA). A seguir, as amostras foram amplificadas por 35 ciclos sendo que cada ciclo corresponde às seguintes etapas: desnaturação a $94{ }^{\circ} \mathrm{C}$ por 1 minuto, hibridização a $55{ }^{\circ} \mathrm{C}$ por 1 minuto e extensão a $72{ }^{\circ} \mathrm{C}$ por 1 minuto. Ao final dos 35 ciclos tem-se uma nova extensão a $72{ }^{\circ} \mathrm{C}$ por 5 minutos.

Os produtos resultantes dos ensaios de PCR foram então diluídos em tampão type II e submetidos à eletroforese em gel de agarose $1,5 \%$ contendo $0,8 \mu \mathrm{g} / \mathrm{ml}$ de brometo de etídeo e utilizando-se o 100 bp como marcador de peso molecular. A corrida eletroforética foi realizada em tampão TBE a 5,5 V/cm.

A gelatina, o Tris- $\mathrm{HCl}$ e o $\mathrm{KCl}$ foram obtidos da Merck (Darmstadt, Alemanha). A procedência dos demais reagentes bem como a composição das soluções utilizadas neste procedimento está descritas nos itens anteriores

\subsubsection{Real Time PCR}

A técnica de Real Time PCR consiste na detecção do aumento, relativo ou absoluto, dos produtos de PCR com o decorrer dos ciclos de amplificação (USER bulletin, 
1997). Neste estudo, a quantificação relativa dos transcritos de interesse foi realizada utilizando-se o fluoróforo SYBR Green.

Os oligonucleotídeos utilizados nas reações de Real Time PCR foram desenhados de modo a amplificar uma região entre dois exons para evitar que o DNA, que porventura tenha permanecido na amostra de RNA mesmo após o tratamento com DNase I, interferisse nas análises de expressão. Além disso, para as análises por Real Time PCR, é recomendado que os oligonucleotídeos utilizados gerem um produto de 50-150 bp (PROTOCOL - SYBR Green PCR and RT-PCR reagents, 1998).

O gene utilizado para a normalização das reações de Real Time PCR foi o GAPDH (Gliceraldeído 3-fosfato desidrogenase). Com o objetivo de determinar se o GAPDH seria realmente o melhor gene de referência para os modelos experimentais utilizados neste trabalho, foi realizada uma análise através do algoritmo geNorm (VANDESOMPELE et al., 2002; <http://medgen.ugent.be/ jvdesomp/genorm/>) comparando-se três genes, além do GAPDH, já utilizados como normalizadores das reações de Real Time PCR por outros autores. Esta análise mostrou que entre os genes GAPDH, ACTB (beta actina), HPRT1 (hipoxantina fosforibosil transferase 1) e RPLP1 (grande proteína ribossomal P1), os genes GAPDH e RPLPl seriam os que sofrem menor variação da expressão entre os tratamentos realizados no modelo experimental utilizado neste trabalho. Em adição, a curva de amplificação obtida após a Real Time PCR mostra que a amplificação do GAPDH sofre uma variação de expressão muito pequena entre as células MCF-7 submetidas aos diferentes tratamentos ao contrário do observado para os genes alvo PAWR e PHLDA1. Por estes motivos, o GAPDH continuou a ser utilizado como gene normalizador das reações de Real Time PCR realizadas neste estudo.

O cDNA sintetizado foi utilizado para a amplificação, em duplicata, do gene de controle, GAPDH, e dos genes de interesse através do Power SYBR Green PCR Master Mix (Applied Biosystems, Warrington, UK) e dos equipamentos GeneAmp 5700 ou 7500 Sequence Detection System (Applied Biosystems, Califórnia, EUA) seguindo as recomendações do fabricante.

As etapas da amplificação dos cDNAs pela técnica de Real Time RT-PCR utilizando o corante SYBR Green foram as seguintes: incubação a $50{ }^{\circ} \mathrm{C}$ por 2 minutos para ativação da enzima Amp-Erase Uracil-N-Glycosylase (UNG) a qual remove amplicons indesejados digerindo as sequiências que contêm U (uracila) ao invés de T (timina); um ciclo de $95^{\circ} \mathrm{C}$ por 10 minutos para a ativação da enzima AmpliTaq Gold e inativação da UNG; e 
40 ciclos consistindo de $95{ }^{\circ} \mathrm{C}$ por 15 segundos para desnaturação do DNA e $55^{\circ} \mathrm{C}$ por 1 minuto para a hibridização dos oligonucleotídeos à fita de DNA.

No início da amplificação as moléculas de SYBR Green não estão ligadas ao DNA e, por isso, emitem pouca fluorescência gerando um background que é excluído durante a análise dos dados. Na etapa de hibridização as moléculas de SYBR Green são incorporadas à dupla fita de DNA que está sendo sintetizada e o aumento da fluorescência emitida sob excitação luminosa (lâmpada de halogênio) é monitorado, ao final de cada ciclo por um sistema óptico capaz de capturar comprimentos de onda entre $530 \mathrm{~nm}$ - $590 \mathrm{~nm}$ (USER Bulletin, 1997; GENEAMP ${ }^{\circledR} 5700$ Sequence Detection Sequence).

Os dados coletados são processados pelo 5700 ou 7500 System Software e ao término do procedimento obtém-se a representação gráfica (Amplification Plot) do aumento relativo da fluorescência resultante da ligação do SYBR Green ao cDNA no decorrer dos ciclos de amplificação. A partir do Amplification Plot, estabelece-se o CT (Threshold Cycle) que se refere ao ciclo de amplificação no qual cada amostra apresenta amplificação exponencial excluindo os backgrounds. Ao final da reação, obtém-se também a curva de dissociação dos oligonucleotídeos para a análise da especificidade do produto amplificado e do padrão de amplificação de cada amostra garantindo assim a qualidade da reação e, conseqüentemente, dos resultados.

O nível de expressão gênica foi determinado pela seguinte fórmula: $2^{-\Delta \Delta C T}$, onde $\Delta \mathrm{CT}$ corresponde à diferença entre a média do CT da amostra amplificada para o gene alvo e a média do CT da mesma amostra amplificada para o gene controle (GAPDH) e $\triangle \triangle \mathrm{CT}$ corresponde à diferença entre o $\Delta \mathrm{CT}$ da amostra de interesse e o $\Delta \mathrm{CT}$ da amostra que será utilizada como referência (SN, Soro Normal).

Para cada par de oligonucleotídeos utilizados, foi realizada a padronização da PCR e, posteriormente, a padronização da concentração ideal de oligonucleotídeos e da diluição adequada do cDNA para a Real Time PCR.

\subsection{Extração das Proteínas}

Para a extração das proteínas, a monocamada de células foi desagregada com a utilização de PBS-EDTA (PBS-A + 1,0 mM EDTA) e ajuda de um scrapper. Este conteúdo foi transferido para tubo cônico de $15,0 \mathrm{ml}$ e centrifugado por 2 minutos a 2000 r.p.m. a temperatura ambiente. A seguir, o sobrenadante foi descartado e o pellet ressuspenso em 
4,0 ml de PBS-A. Novamente, procedeu-se uma centrifugação a temperatura ambiente por 2 minutos a 2000 r.p.m., seguida da retirada do sobrenadante. O pellet resultante foi então ressuspenso no volume adequado de tampão de lise $\left(50,0 \mathrm{mM} \mathrm{Na} \mathrm{P}_{2} \mathrm{O}_{7} ; 50,0 \mathrm{mM} \mathrm{NaF}\right.$; 5,0 mM NaCl; 5,0 mM Na 2 EDTA; 5,0 mM EGTA; 10,0 mM Hepes; 0,5 \% Triton X-100; 2,0 mM Na $3 \mathrm{VO}_{4}$; Protease Inhibitor Cocktail na concentração final de 1:100) e transferido para tubo cônico de 1,5 ml. Pode-se também lavar a monocamada de células por três vezes com PBS-A e, após a última lavagem, retirar totalmente a solução de PBS-A, adicionar o volume adequado de solução de lise e transferir o lisado para tubos cônicos de 1,5 ml.

As amostras foram incubadas por 15 minutos no gelo, homogeneizando algumas vezes para o pellet não se concentrar no fundo do tubo. Após o período de incubação, as amostras foram centrifugadas a 13000 r.p.m por 15 minutos a $4{ }^{\circ} \mathrm{C}$. O sobrenadante foi então transferido para um novo tubo cônico de $1,5 \mathrm{ml}$ e estocado a $-70{ }^{\circ} \mathrm{C}$ até o momento do uso.

A quantificação do extrato protéico foi realizada pelo método de Bradford utilizando-se como curva padrão uma diluição seriada de BSA (componente do Coomassie Plus - The Better Bradford Assay ${ }^{\mathrm{TM}}$ Kit, Pierce, Rockford, EUA) nas concentrações de 0,0 a 1,0 mg/ml. O extrato protéico foi diluído 1:5 ou 1:10 em $\mathrm{H}_{2} \mathrm{O}$ DNase/RNase free (Invitrogen, Grand Island, EUA) para leitura. Em uma placa de 96 poços apropriada, foram pipetados 5,0 $\mu \mathrm{l}$ das diluições de BSA bem como 5,0 $\mu$ l dos extratos protéicos diluídos a serem quantificados. A seguir, foram adicionados 295,0 $\mu$ l do Coomassie Plus - The Better Bradford Assay $^{\mathrm{TM}}$ Kit (Pierce, Rockford, EUA) em cada poço e a placa foi incubada por 10 minutos a temperatura ambiente. A leitura foi realizada no Biotrak II Plate Reader (Amersham Biosciences, Cambridge, Inglaterra) à $595 \mathrm{~nm}$. Os valores das absorbâncias foram plotados em um gráfico no Microsoft® Office Excel® 2007 (Microsoft Corporation, Redmond, EUA) onde as absorbâncias da curva padrão serviram como referência para a quantificação dos extratos protéicos.

Os reagentes utilizados neste procedimento foram obtidos da MP Biomedicals, Solon, EUA $\left(\mathrm{Na}_{4} \mathrm{P}_{2} \mathrm{O}_{7}\right.$; EGTA, $\mathrm{Na}_{3} \mathrm{VO}_{4}$, Ponceau S); Synth, São Paulo, Brasil (NaF); Sigma Chemical Corporation, St. Louis, EUA (Protease Inhibitor Cocktail, Hepes) e USB, Cleveland, EUA (Triton X-100). A procedência dos demais reagentes bem como a composição das soluções utilizadas neste procedimento estão descritas nos itens anteriores. 


\subsubsection{Western Blot}

Trinta microgramas do extrato protéico foram aliquotados em tubos de 1,5 ml aos quais adicionou-se o tampão Laemmli 6,0 X (7,5\% Tris 2,0 M pH 6,8; 0,5 \% SDS; 5 \% azul de bromofenol; $26 \%$ glicerol; 16,5\% de 2-mercaptoetanol) no volume apropriado para se obter uma concentração final de $1,0 \mathrm{X}$. A seguir, as amostras foram aquecidas a $95{ }^{\circ} \mathrm{C}$ durante 5 minutos e aplicadas no gel.

Para a realização da eletroforese foram preparados dois géis SDS-PAGE: um gel de separação $10 \%(375,0 \mathrm{mM}$ Tris- $\mathrm{HCl}, \mathrm{pH} 8,8$; o volume adequado de acrilamida $40 \%$ / Bis-acrilamida 37,5:1; 0,1 \% SDS; 0,045 \% APS; 0,5 $\mu \mathrm{l} / \mathrm{ml}$ TEMED) para a separação das proteínas e, sobre este, um gel de empilhamento $4 \%$ (125,0 mM Tris-HCl, pH 6,8; o volume adequado de $40 \%$ acrilamida/Bis-acrilamida 3,75:1; 0,1 \% SDS; 0,05\% APS; 1,0 $\mu \mathrm{l} / \mathrm{ml}$ TEMED). O tampão de corrida utilizado foi o Tris-Glicina (3,0 g/l Tris Base; 14,5 g/l Glicina) contendo 0,1\% de SDS e o marcador de peso molecular utilizado foi o ColorBurst ${ }^{\mathrm{TM}}$ Electrophoresis Marker (Sigma Chemical Corporation, St. Louis, EUA). A corrida eletroforética iniciou-se a $70 \mathrm{~V}$ por 30 minutos ou até que as amostras passassem pelo gel de empilhamento, e continuou a $100 \mathrm{~V}$ por 1 hora e 20 minutos. Terminada a corrida, as proteínas foram transferidas para a membrana de nitrocelulose (Pierce, Rockford, EUA) utilizando-se o Trans-Blot SD Semi-dry Transfer Cell (Bio-Rad, EUA) e o tampão de transferência Tris-Glicina (5,8 g/l Tris Base; 2,9 g/l Glicina) contendo $20 \%$ de metanol e $0,0375 \%$ de SDS. A transferência foi realizada sob uma corrente elétrica de $15 \mathrm{~V}$ por 50 minutos.

A seguir, a membrana foi incubada, sob agitação, em solução de leite em pó desnatado $5 \%$ (diluído em tampão TBS-t: 2,42 g/l Tris Base; 8,0 g/l NaCl; 0,1 \% Tween 20) durante $1 \mathrm{~h}$ à temperatura ambiente ou por $15 \mathrm{~h} \mathrm{a} 4^{\circ} \mathrm{C}$ para bloqueio dos sítios inespecíficos. A seguir, a membrana foi lavada por quatro vezes de 5 minutos a temperatura ambiente, sob agitação, com tampão TBS-t e por uma vez de 10 minutos com tampão TBS (2,42 g/l Tris Base; 8,0 g/l NaCl) para então ser incubada, sob agitação, por $1-2 \mathrm{~h}$ a temperatura ambiente, com o anticorpo primário diluído na solução de leite em pó desnatado $5 \%$. Passado o período de incubação, a membrana foi lavada por quatro vezes de 5 minutos com TBS-t, por uma vez de 10 minutos com TBS e incubada, sob agitação, por $1 \mathrm{~h}$ a temperatura ambiente, com o anticorpo secundário também diluído na solução de leite em pó desnatado $5 \%$. Após esta incubação a membrana foi novamente lavada por quatro vezes de 5 minutos a temperatura ambiente, sob agitação, com TBS-t e uma vez de 10 minutos com TBS. A detecção das 
proteínas foi realizada por reação quimioluminescente utilizando-se o ECL Western Blotting Detection Reagents (GE healthcare, Buckinghamshire, UK), de acordo com as recomendações do fabricante, seguida pela exposição em filme de raio-X Amershan Hiperfilm ${ }^{\mathrm{TM}}$ ECL (GE healthcare, Buckinghamshire, UK) ou Ortho CP-G (AGFA, Florêncio Varela, Argentina) à temperatura ambiente. As diluições de anticorpos primários e secundários utilizados nos experimentos de western blot estão descritas na tabela 1. As membranas foram estocadas em tampão TBS a $4{ }^{\circ} \mathrm{C}$ para uso posterior. As análises de expressão protéica foram realizadas por densitometria utilizando a expressão da $\beta$-actina como normalizador da massa. As análises densitométricas foram realizadas no software ChemiImager ${ }^{\mathrm{TM}} 4400$ (Alpha Innotech Corporation, San Leandro, EUA).

Quando necessário, a membrana já hibridizada passou pelo processo de stripping (retirada dos anticorpos) para reutilização. Neste processo a membrana é mergulhada na solução de stripping (50,0 mM de tampão Tris pH 6,8; 2 \% de SDS e 0,1 M $\beta$ mercapto etanol), incubada por 20 minutos a $50{ }^{\circ} \mathrm{C}$ sob leve agitação e lavada por quatro vezes de 5 minutos com tampão TBS-t e uma vez de 10 minutos com tampão TBS, a temperatura ambiente sob agitação. Realiza-se então uma nova reação quimioluminescente e exposição a filme de raio-X por no mínimo 30 minutos para análise da qualidade do stripping. A seguir, a membrana é novamente lavada com solução TBS-t por 5 minutos a temperatura ambiente sob agitação por 2 vezes. Neste ponto pode-se realizar o bloqueio da membrana para incubação com os novos anticorpos.

Os reagentes utilizados neste experimento cuja procedência não foi descrita nos itens anteriores foram obtidos da Gibco, Grand Island, EUA (SDS, APS, bis-acrilamida, acrilamida, TEMED); MP Biomedicals, Solon, EUA (Tween 20, glicina); Merck, Darmstadt, Alemanha (ácido acético) e Nestlé, São Paulo, Brasil (leite em pó desnatado Molico). A composição das soluções utilizadas neste experimento também está descrita nos itens anteriores.

\subsection{Análise Estatística}

Os resultados foram analisados por one-way ANOVA utilizando o programa SPSS (Statistical Package for the Social Sciences) for windows 10.1.0, 2000 (SPSS Inc., Chicago, EUA) e os valores de p foram calculados utilizando-se o teste de Bonferroni. Foram considerados valores significativamente diferentes, aqueles com $\mathrm{p} \leq 0,05$. 


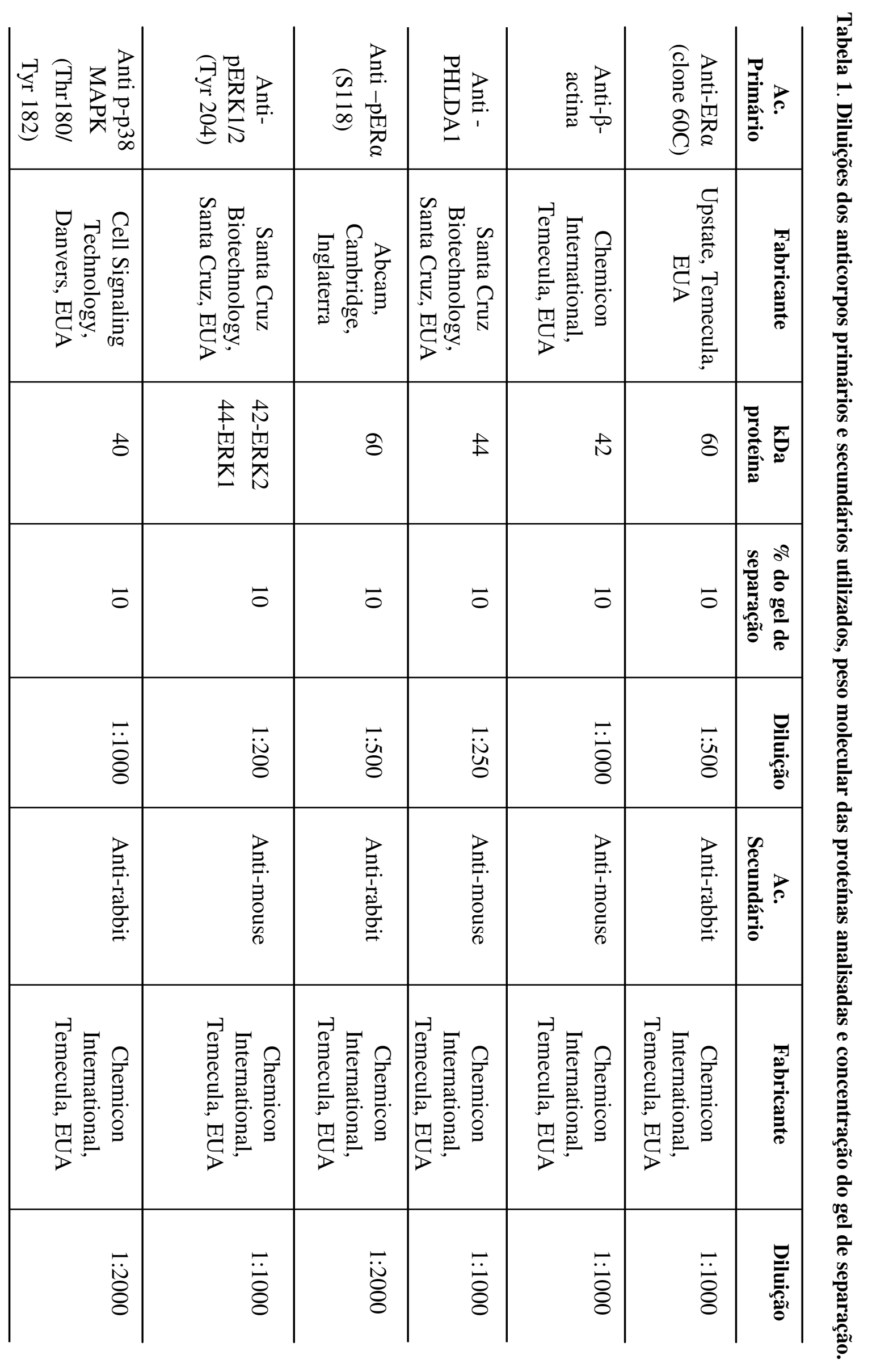




\section{RESULTADOS}

\subsection{Padronização das condições de tratamento das células MCF-7}

Com o objetivo de analisar as diferenças de expressão gênica decorrentes da manutenção das células MCF-7 em ambiente pobre em esteróides e em outros fatores de soro por diferentes intervalos de tempo, realizou-se um experimento no qual estas células foram mantidas em $5 \%$ de soro tratado (ST, soro tratado com carvão dextrana) ou $1 \%$ de soro normal (SC, Soro Carenciado) por 24 h, 48 h, 72 h, 96 h e 120 h. No ponto de $120 \mathrm{~h}$ foram realizados tratamentos com $10^{-8} \mathrm{M}$ e $10^{-9} \mathrm{M}$ de $\mathrm{E} 2$ (17 $\beta$-estradiol) por $6 \mathrm{~h}$ com o intuito de observar a resposta dessas células ao estradiol após um longo período de carenciamento de esteróides e de outros fatores de soro. Como descrito em Material e Métodos, as amostras de RNA total obtidas foram tratadas com DNase I para a posterior síntese do cDNA. Um gel de agarose representativo da análise da qualidade das amostras de RNA total extraídas está mostrado na figura 10. Os cDNAs sintetizados, por sua vez, foram analisados quanto à sua qualidade e homogeneidade da massa obtida através da amplificação com a utilização de oligonucleotídeos para os genes $\beta$-2-microglobulina e GAPDH (Figura 11).

A análise da expressão do gene $P A W R$ - cujos transcritos foram identificados como negativamente regulados pelo $17 \beta$-estradiol e positivamente regulados pela ausência de esteróides e outros fatores de soro - mostrou que a manutenção das células em soro tratado conduziu a um aumento gradativo da expressão deste gene em função do tempo. Os tratamentos com E2 por $6 \mathrm{~h}$, realizados após $120 \mathrm{~h}$ de cultivo em ST, promoveram a diminuição da expressão do $P A W R$ em relação ao ST-120 h sendo que o tratamento com $10^{-8} \mathrm{M}$ de E2 se mostrou mais efetivo, reduzindo em duas vezes a expressão deste gene quando comparado à expressão observada no ponto ST-120 h. Os ensaios utilizando $1 \%$ de soro normal (SC), bem como os respectivos tratamentos com E2, não conduziram a grandes variações na expressão do $P A W R$ (Figura 12). Esses dados mostram que devemos continuar utilizando o ST para a obtenção de um meio pobre em esteróides em nossos experimentos. Em adição ao resultado obtido neste experimento, no qual o tratamento com $10^{-8} \mathrm{M}$ de E2 mostrou-se mais efetivo em relação ao tratamento com $10^{-9} \mathrm{M}$, um ensaio prévio utilizando os tratamentos com $10^{-7}, 10^{-8}, 10^{-9}, 10^{-10}$ e $10^{-11} \mathrm{M}$ de E2 por $2 \mathrm{~h}, 6 \mathrm{~h}$ e $24 \mathrm{~h}$ nas células MCF-7 também mostrou que a concentração $10^{-8} \mathrm{M}$ de E2 é a mais eficiente em qualquer um dos intervalos de tempo testados (MARCHIORI, 2007). Assim, a concentração de $10^{-8} \mathrm{M}$ de E2 continuou a ser utilizada nos experimentos posteriores. 


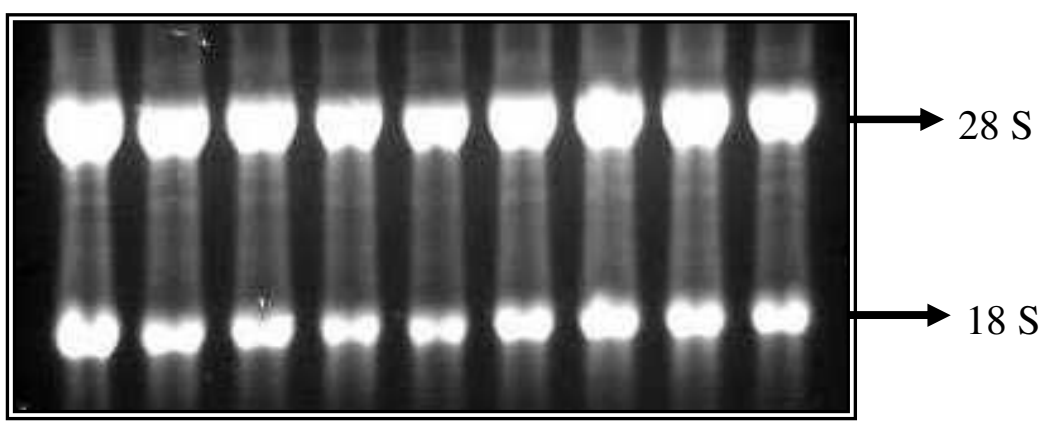

Figura 10. Análise da qualidade e integridade do RNA extraído das células MCF-7 pela técnica guanidina fenol-clorofórmio.

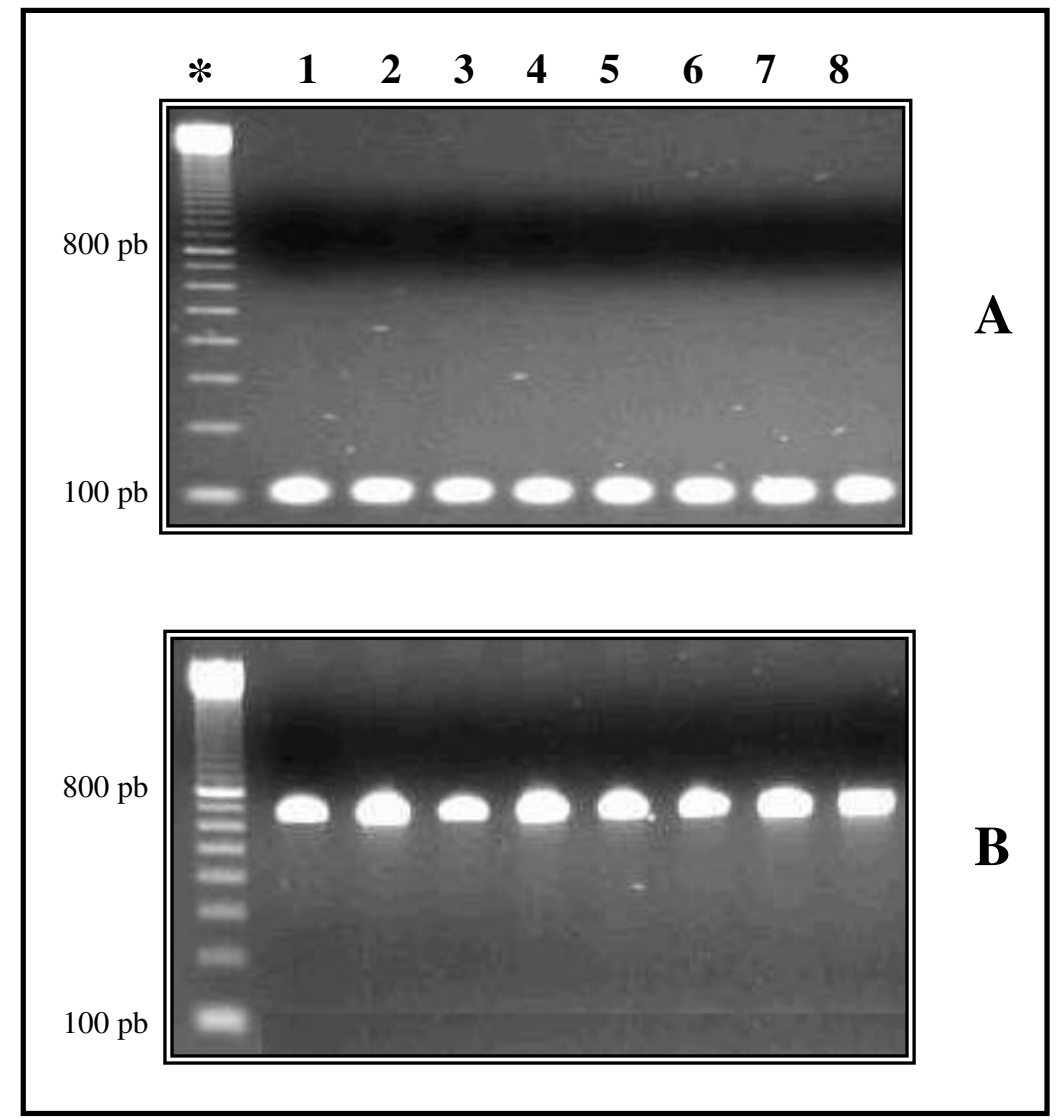

Figura 11. Amplificação dos genes GAPDH (A) e $\beta$-2-microglobulina (B) para análise da qualidade e da homogeneidade da massa dos cDNAs sintetizados. *, Marcador de peso molecular $100 \mathrm{pb}$; 1-8, amostras de cDNA das células MCF-7 submetidas aos diferentes tratamentos com E2, tamoxifen e EGF. 


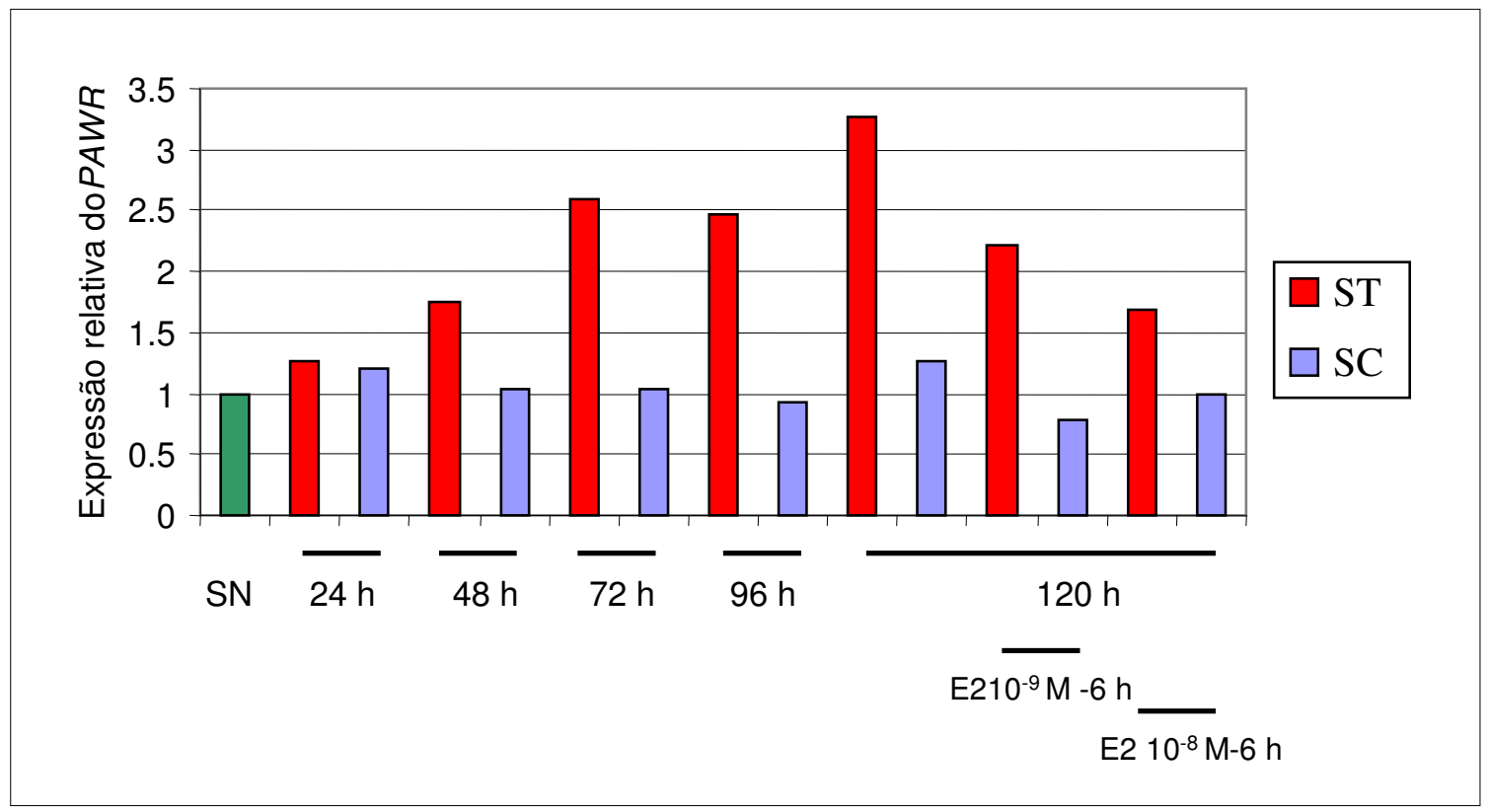

Figura 12. Efeito das diferentes condições de cultura na expressão relativa do gene $P A W R$ nas células MCF-7. A expressão relativa foi determinada por Real Time PCR. SN, Soro Normal (células mantidas em soro fetal bovino); ST, Soro Tratado (células mantidas em soro fetal bovino tratado com carvão dextrana); SC, Soro Carenciado (células mantidas em $1 \%$ de soro normal); E2, 17ß-estradiol. As barras representam a expressão relativa do gene $P A W R$ nas diferentes condições de cultura em relação às células mantidas em $\mathrm{SN}$. 
Para avaliar as melhores condições de tratamento das células MCF-7 com EGF realizou-se um experimento, em duplicata, utilizando diferentes concentrações de EGF (20, 50 e 100,0 ng/ml) por diferentes intervalos de tempo (1 h, 2 h, 6 h e 24 h) após manutenção das células em soro livre de esteróides (ST) por 48 h e 120 h. A análise do primeiro experimento da duplicata mostrou que não houve variação significativa da expressão do gene $H N R P K$ nas células mantidas em ST por $48 \mathrm{~h}$ quando comparada às células mantidas em SN e que o tratamento com 100,0 ng/ml de EGF por 6h seria a melhor condição de ensaio pois, sob esta condição, o $H N R P K$ apresentou um pequeno aumento de expressão em relação às células mantidas em ST-48 h (Figura 13), fato que não havia sido observado nos experimentos anteriores. Entretanto, quando repetiu-se a análise de expressão com o mesmo experimento, utilizando os tratamentos considerados mais interessantes e acrescentando o ensaio realizado após manutenção das células por $120 \mathrm{~h}$ em ST, observou-se que nenhum dos tratamentos conduziu a uma variação significativa da expressão do $H N R P K$ não reproduzindo, portanto, o primeiro resultado obtido para este gene (Figura $14 \mathrm{~A}$ ).

Nas análises realizadas para o gene PAWR observou-se um aumento de 9,0 vezes na expressão deste gene nas células mantidas em ST por $48 \mathrm{~h}$ em relação às células mantidas em SN e que todos os tratamentos com EGF induziram a diminuição da sua expressão em relação às células mantidas em ST-48 h (Figura 13). Sendo assim, optou-se por utilizar a concentração de $50,0 \mathrm{ng} / \mathrm{ml}$ de EGF nos experimentos posteriores visto que esta concentração foi utilizada em diversos trabalhos da literatura e mostrou um bom resultado na redução da expressão do $P A W R$ em 1 h, 2 h e 24 h de tratamento. A análise do experimento no qual as células foram mantidas em ST por $120 \mathrm{~h}$ mostrou um aumento de 5,5 vezes na expressão do gene $P A W R$ em relação às células mantidas em $\mathrm{SN}$. Entretanto, os tratamentos com EGF não conduziram ao mesmo efeito observado no ensaio de ST-48 h (Figura 14 B). Este evento pode ser explicado pelo fato de que, após 120 h de manutenção em ST, as células MCF-7 apresentam sinais de estresse (descolamento do frasco de cultura, dificuldade de multiplicação, diferenças na morfologia). Um fato que chama a atenção é a grande variação no aumento de expressão do gene PAWR nas células MCF-7 mantidas em ST entre os diferentes experimentos (Figuras 13 e 16). A utilização de diferentes lotes de soro fetal bovino, o nível de confluência das células no momento dos tratamentos, bem como variações inerentes a cada síntese de cDNA seriam algumas das possíveis explicações para esta variação inter-experimento embora todo o cuidado tenha sido tomado em relação a estas colocações. 


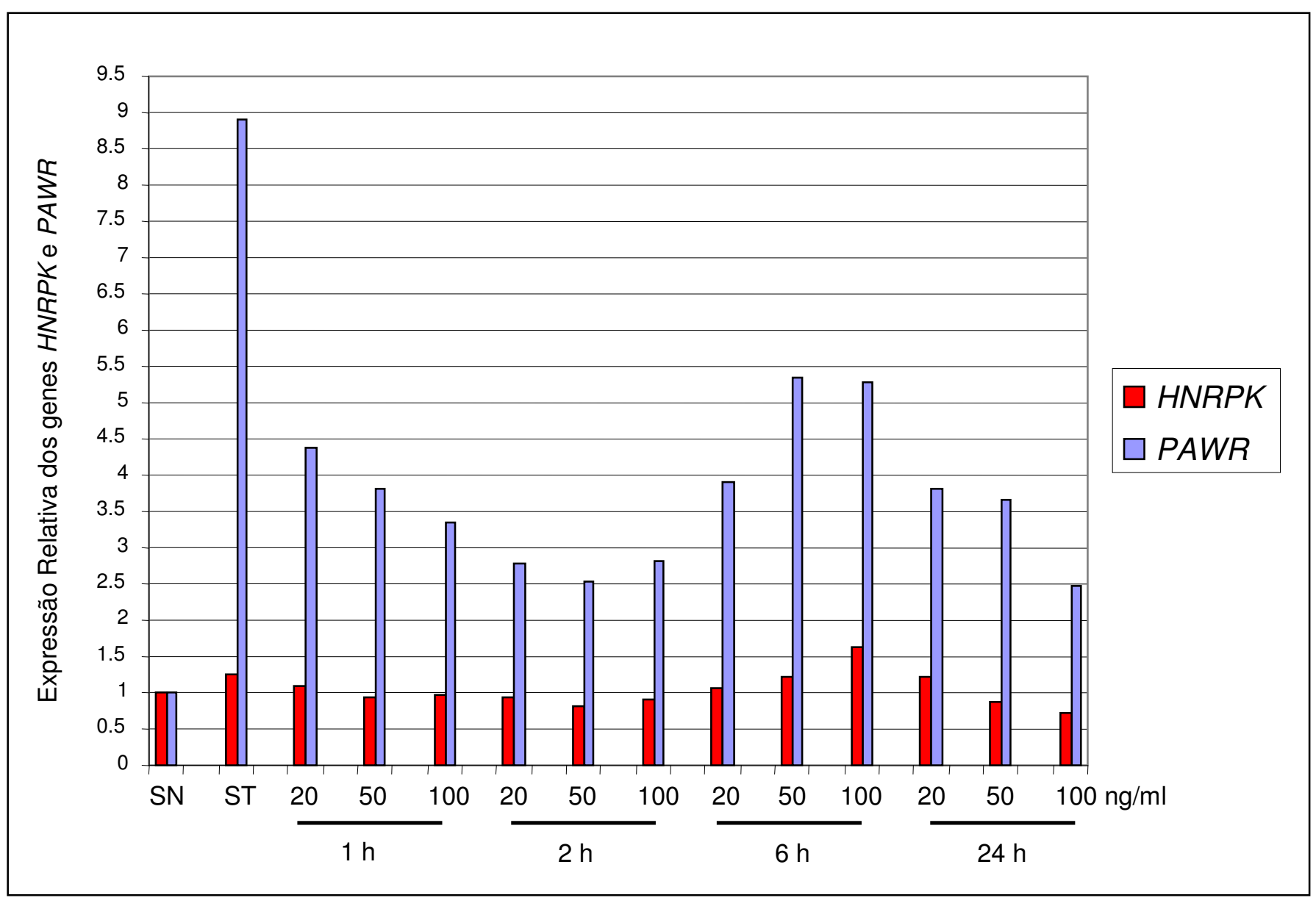

Figura 13. Efeito das diferentes concentrações de EGF (fator de crescimento epidermal) na expressão relativa dos genes $H N R P K$ e $P A W R$ nas células MCF-7. A expressão relativa foi determinada por Real Time PCR. SN, Soro Normal (células mantidas em soro fetal bovino); ST, Soro Tratado (células mantidas em soro fetal bovino tratado com carvão dextrana por $48 \mathrm{~h}$ antes do início dos tratamentos). As barras representam a expressão relativa dos genes $H N R P K$ e $P A W R$ após os tratamentos com EGF nas concentrações de $20,0 \mathrm{ng} / \mathrm{ml}, 50,0 \mathrm{ng} / \mathrm{ml}$ e 100,0 ng/ml por $1 \mathrm{~h}, 2 \mathrm{~h}, 6 \mathrm{~h}$ e $24 \mathrm{~h}$ em relação às células mantidas em SN. 

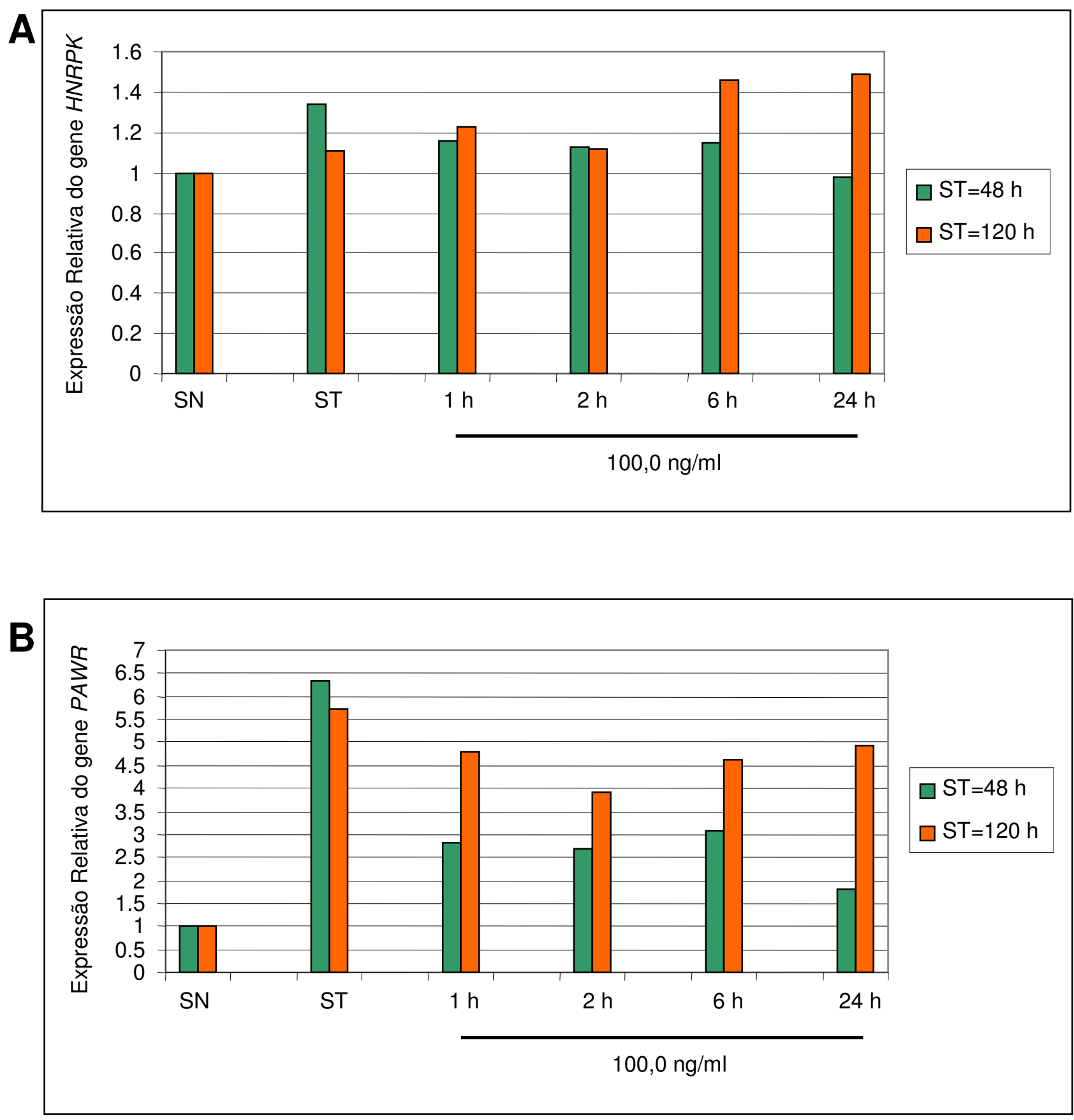

Figura 14. Efeito do EGF (fator de crescimento epidermal) na expressão relativa dos genes HNRPK (A) e PAWR (B) nas células MCF-7. A expressão relativa foi determinada por Real Time PCR. SN, Soro Normal (células mantidas em soro fetal bovino); ST, Soro Tratado (células mantidas em soro fetal bovino tratado com carvão dextrana por $48 \mathrm{~h}$ ou $120 \mathrm{~h}$ antes do início dos tratamentos). As barras representam a expressão relativa dos genes $H N R P K$ (A) e $P A W R$ (B) após o tratamento com EGF na concentração de 100,0 ng/ml por $1 \mathrm{~h}, 2 \mathrm{~h}, 6 \mathrm{~h}$ e 24 h em relação às células mantidas em SN. 
Em função da observação de que o EGF não apresentou efeito no controle da transcrição do gene $H N R P K$ nos experimentos realizados até o momento (Figura 15) decidiu-se por continuar as análises somente para o gene PAWR e incluir o gene PHLDA1 nos nossos estudos.

Devido à dificuldade em determinar o efeito do tamoxifen - o qual é um modificador seletivo do receptor de estrógeno (SERM) - na inibição do ER $\alpha$ nas células MCF-7 passou-se a utilizar o ICI 182,780, um antiestrógeno puro, como antagonista do receptor de estrógeno nos próximos experimentos.

\subsubsection{Efeito do 17ß-estradiol (E2) e do ICI 182,780 na expressão dos genes PAWR e PHLDA1}

Para esta análise, realizou-se um experimento no qual as células MCF-7 foram tratadas com E2 $\left(10^{-8} \mathrm{M}\right)$, ICI $\left(10^{-6} \mathrm{M}\right)$ ou ICI $\left(10^{-6} \mathrm{M}\right)+\mathrm{E} 2\left(10^{-8} \mathrm{M}\right)$ por $2 \mathrm{~h}, 6 \mathrm{~h}$ e $24 \mathrm{~h}$ após a manutenção das células em ST por 48 h. Nos tratamentos com ICI + E2 o ICI foi adicionado ao meio de cultura $1 \mathrm{~h}$ antes de se adicionar o E2. Como pode ser observado na figura 16 , as células mantidas em ST apresentaram um aumento de 2,0 vezes na expressão do gene $P A W R$ quando comparadas às células mantidas em SN. Os tratamentos com E2 promoveram a diminuição da expressão deste gene sendo que o tratamento de 24 h reduziu em 2,0 $( \pm 0,12)$ vezes a expressão do $P A W R$ retomando a expressão observada nas células mantidas em SN. As células tratadas com ICI-2 h e $6 \mathrm{~h}$ mantiveram a expressão observada nas células cultivadas em ST enquanto o tratamento ICI-24 h conduziu a um aumento de 2,5 $( \pm 0,2$; $\mathrm{p}<0,001)$ vezes na expressão de $P A W R$ em relação às células mantidas em ST. Nos tratamentos com ICI + E2 observou-se um aumento gradativo da expressão deste gene em $6 \mathrm{~h}$ (não significativo) e 24 h $(2,0 \pm 0,13$ vezes; $\mathrm{p}<0,001)$ em relação às células mantidas em ST.

$\mathrm{Na}$ análise dos transcritos PHLDAl (Figura 17) observou-se que a manutenção das células em ST não promoveu uma variação significativa na expressão deste gene em relação às células mantidas em $\mathrm{SN}$. $\mathrm{O}$ E2, por sua vez, induziu a expressão do PHLDA1 em $2 \mathrm{~h}, 6 \mathrm{~h}$ e $24 \mathrm{~h}$ de tratamento sendo que o maior aumento de expressão foi observado em $6 \mathrm{~h}$ $(2,25 \pm 0,91$ vezes; $p=0,013)$. Os tratamentos com ICI 182,780 promoveram a diminuição da expressão deste gene em relação às células mantidas em ST, principalmente em $2 \mathrm{~h}(2,1 \pm$ 0,08 vezes) e 6 h (2,2 \pm 0,07 vezes) de tratamento. A adição do E2 após o tratamento das células MCF-7 com ICI 182,780 por 1 hora manteve a expressão semelhante aos tratamentos com ICI 182,780 isoladamente. 


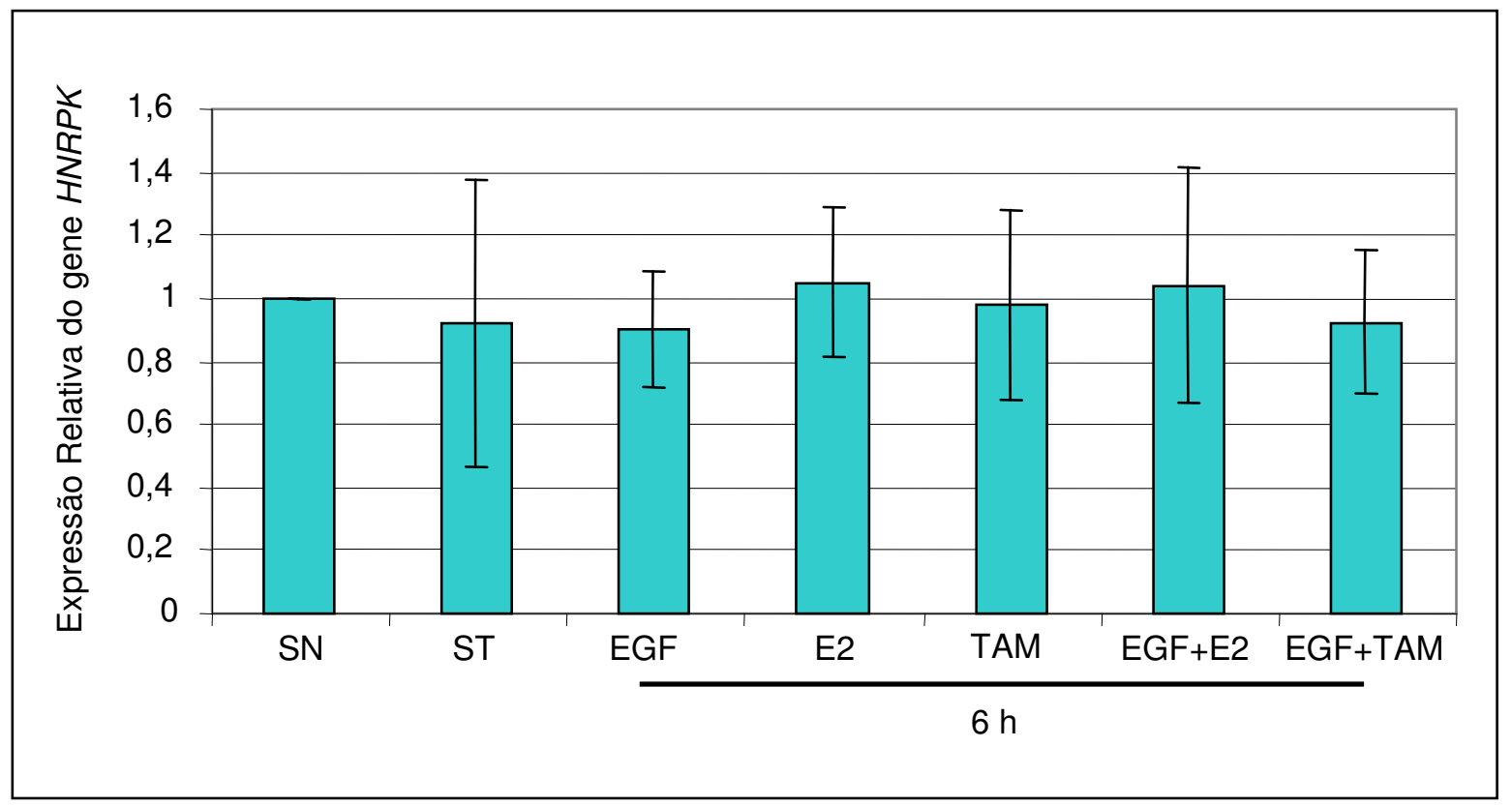

Figura 15. Efeito do EGF (fator de crescimento epidermal), E2 (17 $\beta$-estradiol) e TAM (tamoxifen) na expressão relativa do gene HNRPK nas células MCF-7. A expressão relativa foi determinada por Real Time PCR. SN, Soro Normal (células mantidas em soro fetal bovino); ST, Soro Tratado (células mantidas em soro fetal bovino tratado com carvão dextrana por $48 \mathrm{~h}$ antes do início dos tratamentos). As barras representam a média e o desvio padrão de três experimentos tendo como referência as células mantidas em SN. 


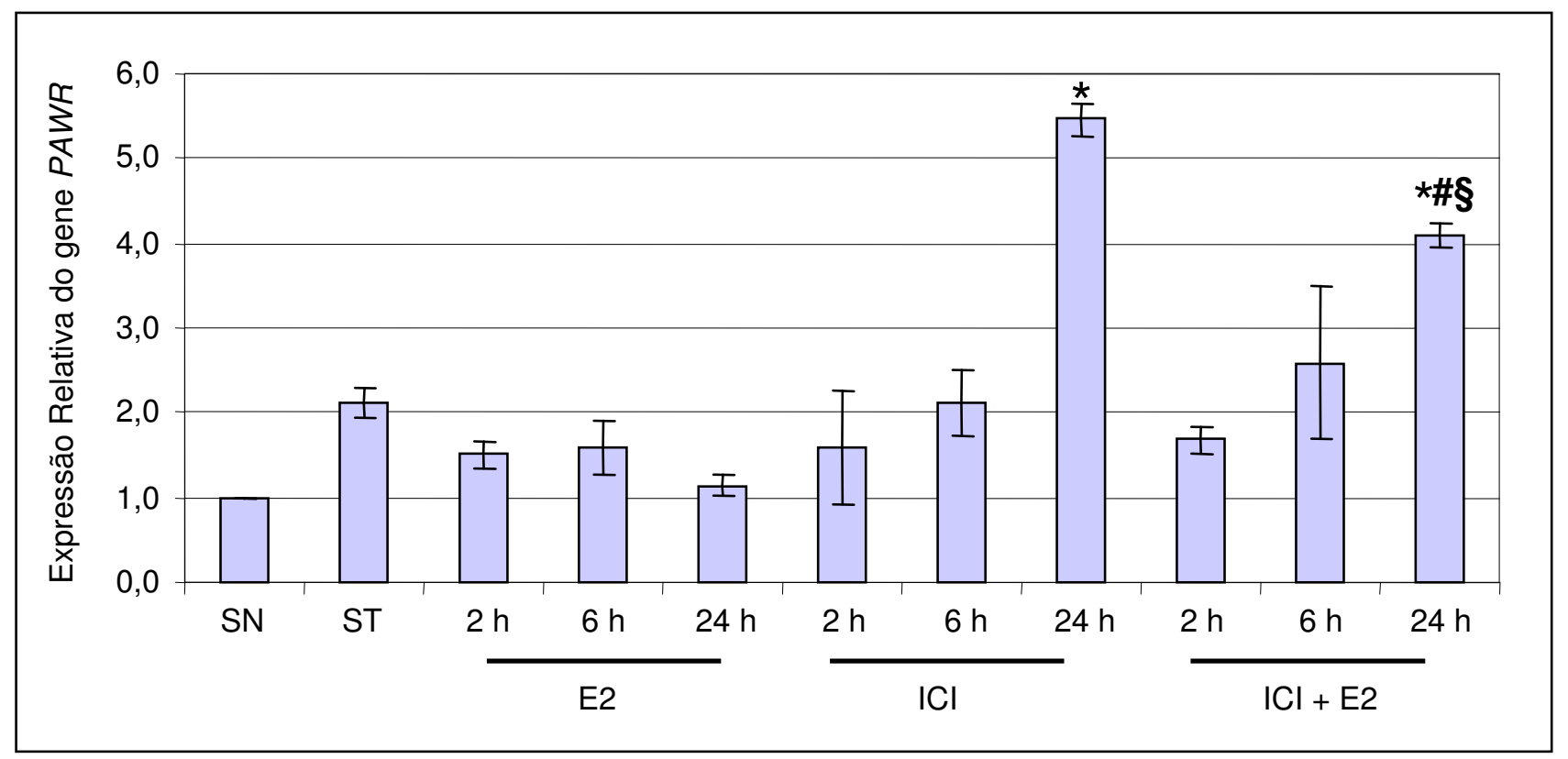

Figura 16. Efeito do E2 (17ß-estradiol) e do ICI (ICI 182,780) na expressão relativa do gene PAWR nas células MCF-7. A expressão relativa foi determinada por Real Time PCR. SN, Soro Normal (células mantidas em soro fetal bovino); ST, Soro Tratado (células mantidas em soro fetal bovino tratado com carvão dextrana por $48 \mathrm{~h}$ antes do início dos tratamentos); *, p $\leq 0,05 \mathrm{em}$ relação ao ST; \#, p $\leq 0,05$ em relação ao tratamento com ICI-24 h; $\S, \mathrm{p} \leq 0,05$ em relação ao tratamento com E2-24 h. As barras representam a média e o desvio padrão de três experimentos tendo como referência as células mantidas em SN. 


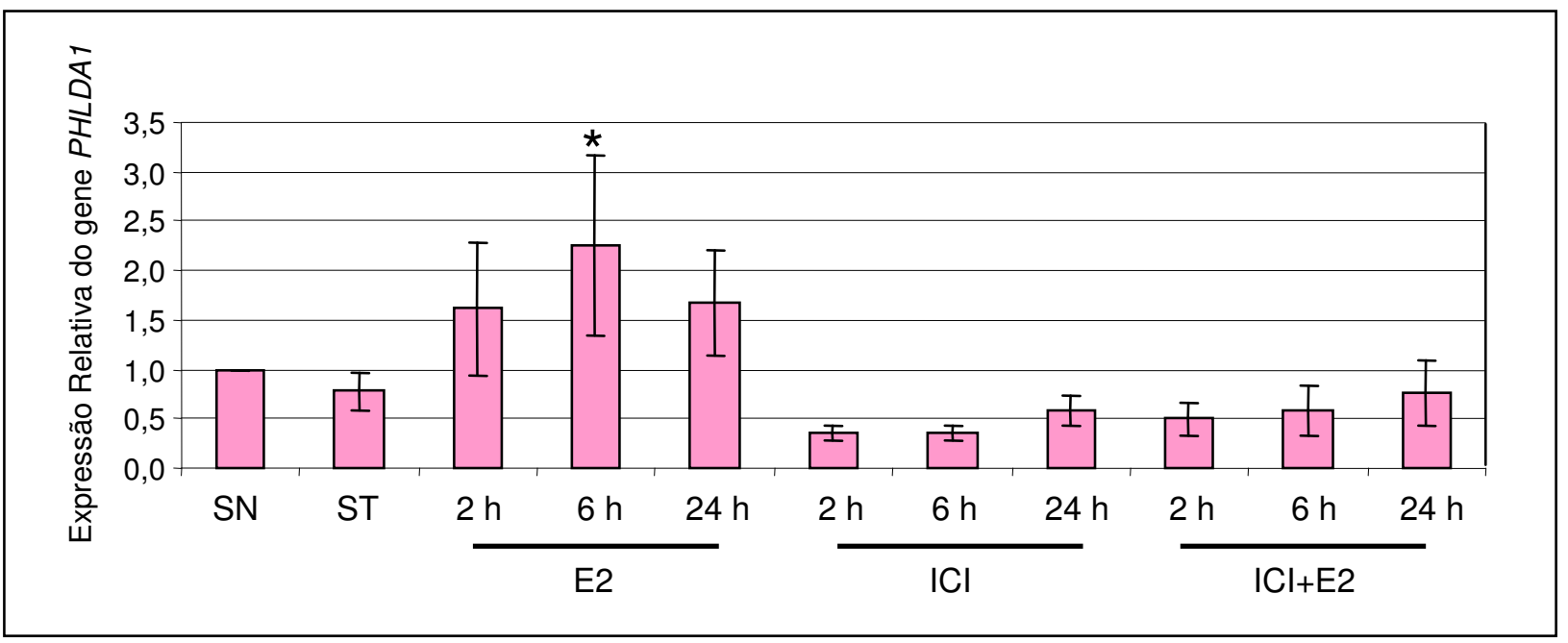

Figura 17. Efeito do E2 (17ß-estradiol) e do ICI (ICI 182,780) na expressão relativa do gene PHLDA1 nas células MCF-7. A expressão relativa foi determinada por Real Time PCR. SN, Soro Normal (células mantidas em soro fetal bovino); ST, Soro Tratado (células mantidas em soro fetal bovino tratado com carvão dextrana por $48 \mathrm{~h}$ antes do início dos tratamentos); *, p $\leq 0,05$ em relação ao ST. As barras representam a média e o desvio padrão de três experimentos tendo como referência as células mantidas em SN. 


\subsubsection{Efeito do EGF e do ICI 182,780 na expressão dos genes PAWR e PHLDAI}

Para avaliar o efeito do EGF e do ICI 182,780 na regulação da expressão dos genes PAWR e PHLDAl as células MCF-7 foram tratadas com EGF (50,0 ng/ml), ICI $\left(10^{-6} \mathrm{M}\right)$ ou ICI $\left(10^{-6} \mathrm{M}\right)+\mathrm{EGF}(50,0 \mathrm{ng} / \mathrm{ml})$ por $2 \mathrm{~h}$ e $24 \mathrm{~h}$ após a manutenção das células em ST por $48 \mathrm{~h}$. Nos tratamentos com ICI + EGF o ICI foi adicionado ao meio de cultura $1 \mathrm{~h}$ antes de se adicionar o EGF.

O efeito do EGF e do ICI 182,780 na expressão do PAWR está representado no gráfico da figura 18 onde observou-se um aumento de 5,0 $( \pm 0,93 ; \mathrm{p}=0,035)$ vezes na expressão deste gene nas células mantidas em ST em relação às células mantidas em $\mathrm{SN}$. Os tratamentos com EGF, ICI e ICI + EGF por 2 h não promoveram variações significativas na expressão deste gene em relação às células mantidas em ST. O tratamento com EGF-24 h promoveu uma redução de $1,5( \pm 0,75)$ vez na expressão do PAWR enquanto o tratamento com ICI-24 h promoveu um aumento significativo na expressão deste gene em relação às células mantidas em ST $(10,8 \pm 2,15$ vs. 5,0 $\pm 0,93 ; \mathrm{p}=0,001)$ como havia sido observado nos experimentos anteriores. $\mathrm{O}$ tratamento com ICI + EGF-24 h manteve a expressão do PAWR semelhante à expressão observada nas células mantidas em ST, porém maior em relação ao tratamento com EGF-24 h e menor, de maneira significativa $(1,8 \pm 0,8 \mathrm{vez} ; \mathrm{p}=0,006)$, em relação ao tratamento com ICI-24 h.

A análise da expressão do PHLDA1 após o tratamento das células MCF-7 com EGF e ICI 182,780 está representada na figura 19. Os resultados obtidos mostraram que a manutenção das células em ST não promoveu uma variação significativa na expressão do PHLDAl em relação às células mantidas em SN. Os tratamentos com EGF por $2 \mathrm{~h}$ e $24 \mathrm{~h}$ promoveram um aumento de 2,8 $( \pm 0,25 ; \mathrm{p}<0,001)$ e $1,4( \pm 0,62)$ vezes, respectivamente, na expressão do PHLDAl em relação às células mantidas em ST. Os tratamentos com ICI 182,780 por 2 h e 24 h não promoveram uma variação significativa da expressão deste gene em relação ás células mantidas em ST. Os tratamentos ICI + EGF por 2 h e 24 h não promoveram variação significativa da expressão do PHLDAl em relação aos respectivos tratamentos com EGF.

Os resultados obtidos sugerem a existência de uma interação entre as vias de sinalização dos estrógenos e fatores de crescimento no controle da transcrição do gene $P A W R$, mas não do PHLDA1. A partir daqui os estudos foram conduzidos no sentido de se confirmar 


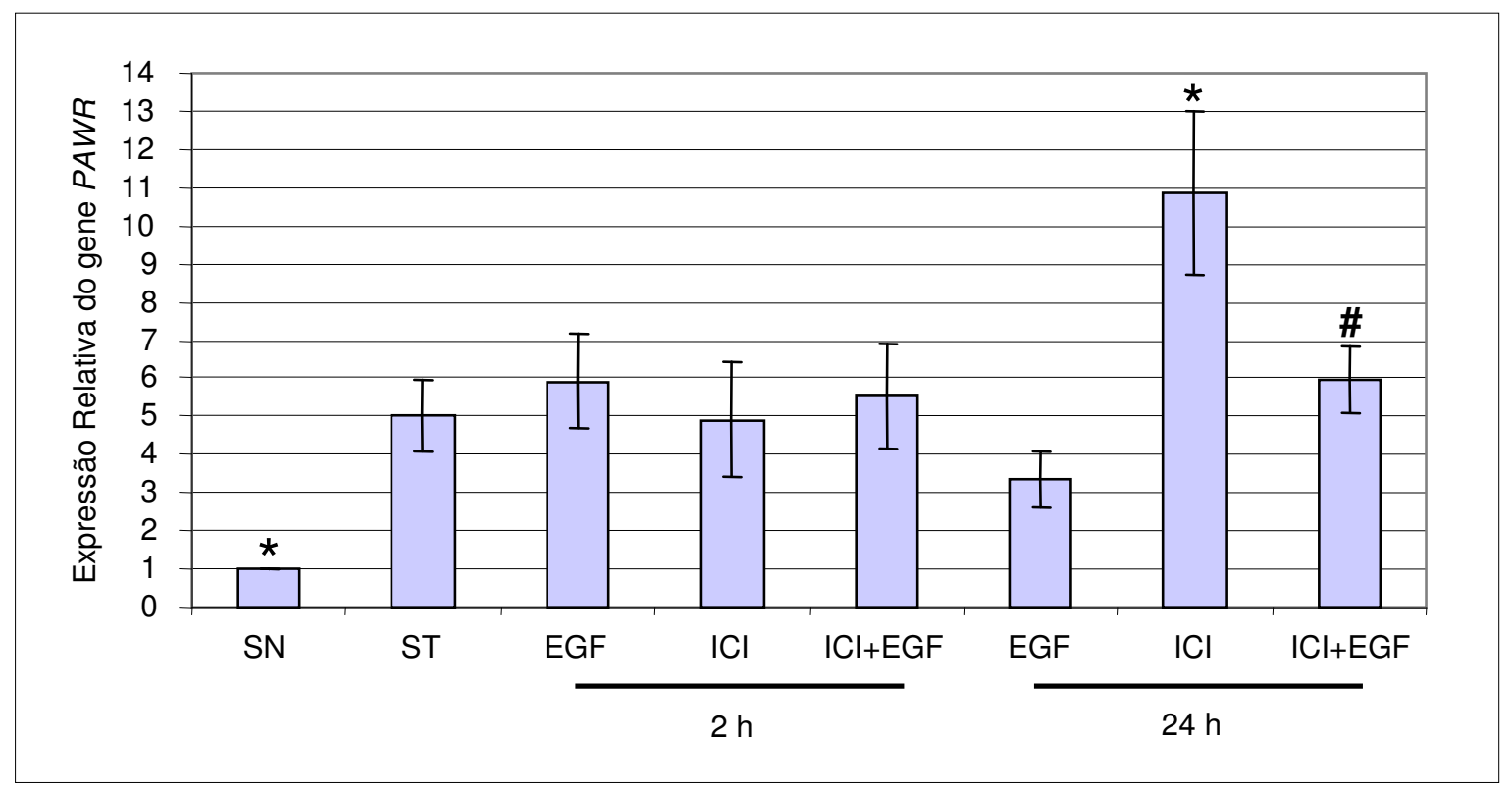

Figura 18. Efeito do EGF (fator de crescimento epidermal) e do ICI (ICI 182,780) na expressão relativa do gene $P A W R$ nas células MCF-7. A expressão relativa foi determinada por Real Time PCR. SN, Soro Normal (células mantidas em soro fetal bovino); ST, Soro Tratado (células mantidas em soro fetal bovino tratado com carvão dextrana por $48 \mathrm{~h}$ antes do início dos tratamentos); ${ }^{*}, \mathrm{p} \leq 0,05$ em relação ao ST; \#, $\mathrm{p} \leq 0,05$ em relação ao tratamento com ICI-24 h. As barras representam a média e o desvio padrão de três experimentos tendo como referência as células mantidas em SN. 


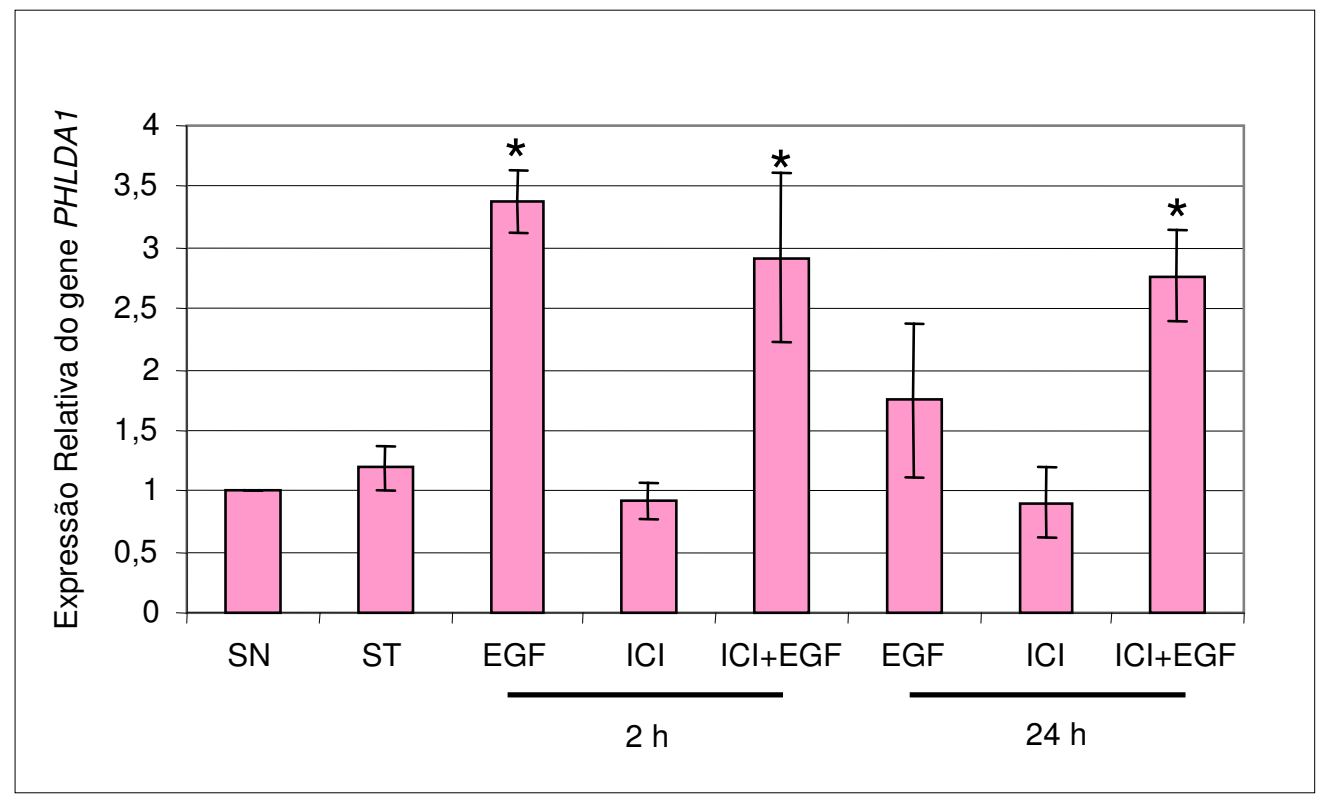

Figura 19. Efeito do EGF (fator de crescimento epidermal) e do ICI (ICI 182,780) na expressão relativa do gene $P H L D A 1$ nas células MCF7. A expressão relativa foi determinada por Real Time PCR. SN, Soro Normal (células mantidas em soro fetal bovino); ST, Soro Tratado (células mantidas em soro fetal bovino tratado com carvão dextrana por $48 \mathrm{~h}$ antes do início dos tratamentos); *, $\mathrm{p} \leq 0,05$ em relação ao ST. As barras representam a média e o desvio padrão de três experimentos tendo como referência as células mantidas em SN. 
estes resultados e determinar qual ou quais as vias de sinalização celular estão envolvidas nesta interação.

\subsubsection{Efeito do 17ß-estradiol (E2), EGF, ICI 182,780 e dos inibidores LY 294002, SB 202190 e PD 98059 na expressão dos genes PAWR e PHLDA1}

A princípio foram realizados três experimentos com o objetivo de confirmar a existência de interação entre as vias de sinalização do E2 e do EGF no controle da transcrição dos genes PAWR e PHLDAl e determinar quais as vias envolvidas neste processo. Entretanto, conforme pode ser observado na figura 20 , houve uma grande diferença no perfil de expressão do gene $P A W R$ entre os experimentos. Tendo em vista estes resultados, levantou-se a hipótese de que a concentração de inibidores utilizada nestes ensaios $(30,0 \mu \mathrm{M})$, além de inibir as respectivas vias, teria um efeito citotóxico o qual poderia explicar esta grande variação entre os experimentos. Para avaliar esta hipótese, foram realizadas curvas de proliferação e de viabilidade das células MCF-7 e MDA-MB-231 utilizando diferentes concentrações de inibidores. As concentrações de inibidores utilizadas foram 1,0 $\mu \mathrm{M}, 5,0 \mu \mathrm{M}, 10,0 \mu \mathrm{M}$ e 30,0 $\mu \mathrm{M}$, conforme dados da literatura. Para a análise da proliferação celular utilizou-se o Vybrant ${ }^{\circledR}$ MTT Cell Proliferation Assay Kit (Invitrogen, Oregon, EUA) e para a análise da viabilidade celular utilizou-se a coloração com Trypan Blue 0,4 \% (Invitrogen Corporation, Grand Island, EUA).

Os resultados obtidos mostraram que, embora os desvios padrões das triplicatas estivessem grandes, a proliferação celular e o número de células viáveis tenderam a ser menores nos tratamentos com 30,0 $\mu \mathrm{M}$. Por esta razão, e levando-se em conta dados da literatura, optou-se por realizar um novo experimento utilizando a concentração de 5,0 $\mu \mathrm{M}$.

A análise deste experimento para o gene PAWR (Figura 21) mostrou que, como havia sido observado nos experimentos anteriores, a manutenção das células MCF-7 em ST promoveu um aumento na expressão deste gene. O tratamento com EGF-2 h manteve a expressão do $P A W R$ semelhante à observada nas células mantidas em ST enquanto o tratamento com EGF-24 h mostrou, novamente, uma tendência em promover a diminuição da expressão deste gene. O tratamento das células com os inibidores LY 294002 (LY, inibidor da via PI3K), SB 202190 (SB, inibidor da via p38 MAPK) e PD 98059 (PD, inibidor da via ERK1/2) por duas horas promoveu uma pequena diminuição da expressão do PAWR em relação às células mantidas em ST. A adição do EGF-2 h após o pré-tratamento das células com o inibidor LY promoveu um aumento na expressão deste gene em relação ao tratamento 


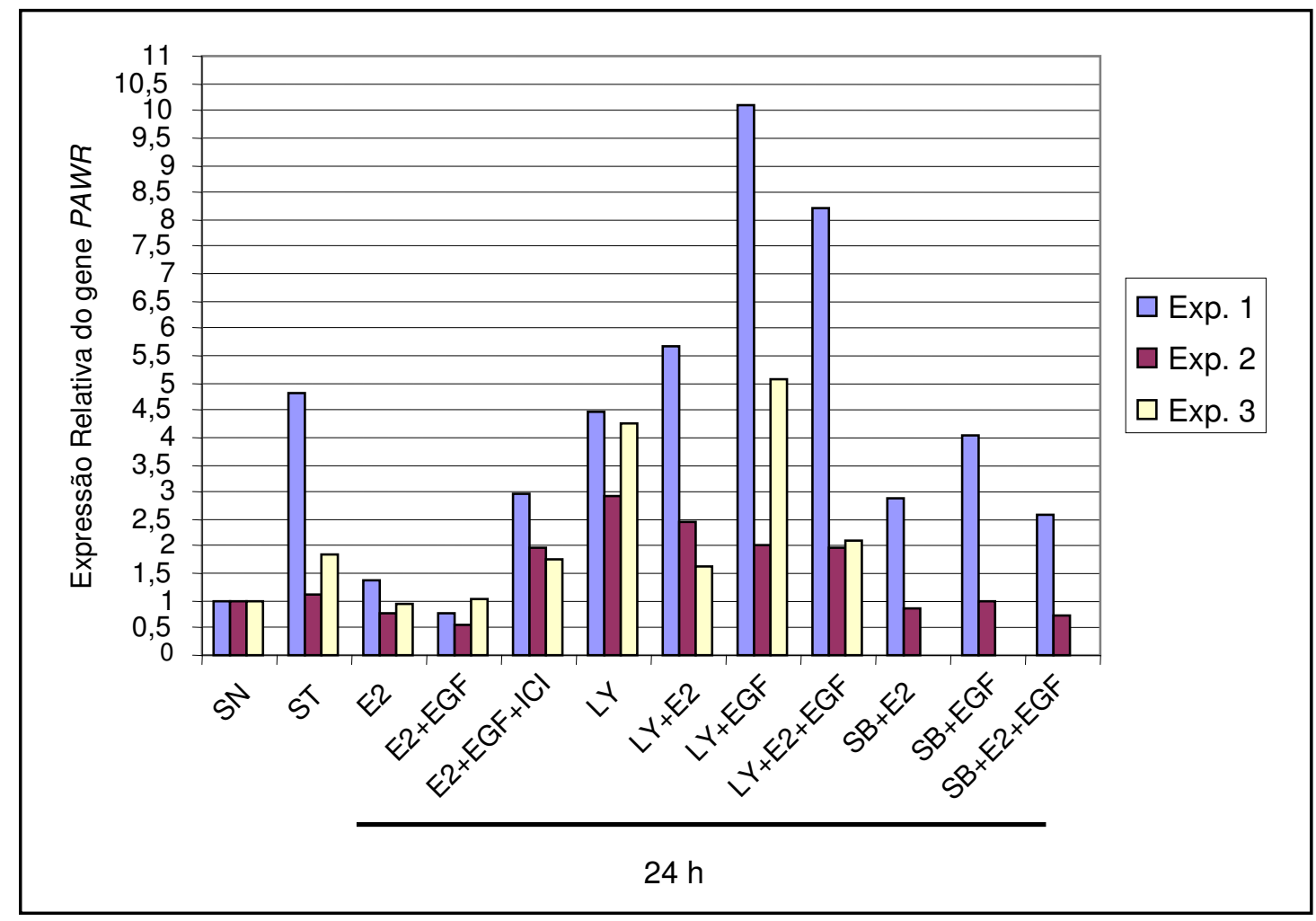

Figura 20. Efeito do E2 (17ß-estradiol), EGF (fator de crescimento epidermal), ICI (ICI 182,780), LY (LY 294002) E SB (SB 202190) na expressão relativa do gene PAWR nas células MCF-7. A expressão relativa foi determinada por Real Time PCR. SN, Soro Normal (células mantidas em soro fetal bovino); ST, Soro Tratado (células mantidas em soro fetal bovino tratado com carvão dextrana por $48 \mathrm{~h}$ antes do início dos tratamentos). As barras representam a expressão relativa do gene $P A W R$ após os diferentes tratamentos em relação as células mantidas em $\mathrm{SN}$. 


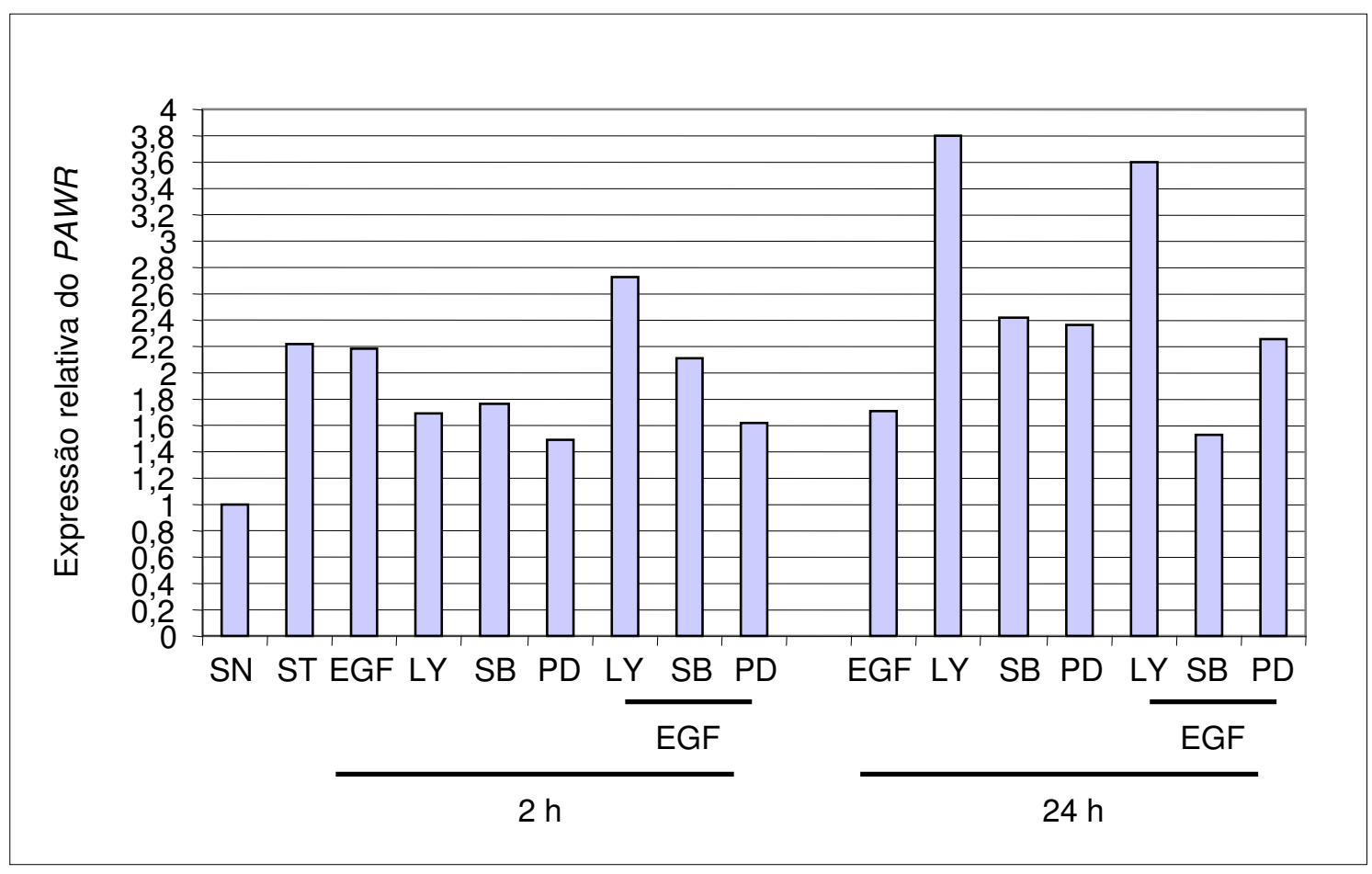

Figura 21. Efeito do EGF (fator de crescimento epidermal), LY (LY 294002), SB (SB 202190) e PD (PD 98059) na expressão relativa do gene PAWR nas células MCF-7. A expressão relativa foi determinada por Real Time PCR. SN, Soro Normal (células mantidas em soro fetal bovino); ST, Soro Tratado (células mantidas em soro fetal bovino tratado com carvão dextrana por $48 \mathrm{~h}$ antes do início dos tratamentos). As barras representam a expressão relativa do gene $P A W R$ após os diferentes tratamentos em relação às células mantidas em $\mathrm{SN}$. 
com EGF-2 h isoladamente; após o pré-tratamento com SB a adição de EGF-2 h manteve a expressão do PAWR semelhante à observada no tratamento com EGF-2 h isoladamente. $\mathrm{O}$ tratamento com PD + EGF-2 h manteve a expressão deste gene semelhante à observada no tratamento com PD-2 h. Ou seja, após a inibição das vias do PI3K e da ERK1/2, o EGF não é capaz de promover o mesmo efeito do tratamento com EGF-2 h isoladamente. Fato semelhante pôde ser observado nos tratamentos de 24 h: o tratamento das células MCF-7 com os inibidores promoveu o aumento da expressão do $P A W R$. O pré-tratamento com LY e SB seguida pela adição de EGF-24 h manteve a expressão deste gene semelhante ao tratamento com LY-24 h e PD-24 h, respectivamente, enquanto que, mesmo na presença do SB o EGF$24 \mathrm{~h}$ conseguiu promover a mesma diminuição de expressão observada no tratamento com EGF-24 h isoladamente.

A análise deste mesmo experimento para o gene PHLDAl está representada na figura 22. Como observado nos experimentos anteriores, não houve variação significativa na expressão do PHLDAl entre as células MCF-7 mantidas em SN e ST. Os tratamentos com EGF-2 h e EGF-24 h promoveram um aumento de 9,0 e 3,5 vezes, respectivamente, na expressão deste gene. Os tratamentos com LY-2 h, SB-2 h e PD-2 h promoveram o aumento da expressão do PHLDAl em relação às células mantidas em ST enquanto os mesmos tratamentos por $24 \mathrm{~h}$ mantiveram a expressão deste gene semelhante à observada nas células mantidas em ST. A adição do EGF-2h após o pré-tratamento das células com os inibidores LY e PD promoveu o aumento da expressão do PHLDAl em relação aos tratamentos com LY-2 h e PD-2 h isoladamente, porém com uma menor eficiência em relação ao tratamento com EGF-2 h. Já o tratamento SB + EGF-2 h conduziu a um aumento de cerca de 16,0 vezes na expressão deste gene. Em relação à adição do EGF-24 h após o pré-tratamento das células com os inibidores LY e SB, pôde ser observado um aumento na expressão do PHLDAl em relação aos tratamentos com os respectivos inibidores por $24 \mathrm{~h}$ e com o EGF-24 h isoladamente. No tratamento PD + EGF-24 h a expressão do PHLDAl ficou semelhante à observada no tratamento com EGF-24 h isoladamente. Estes resultados indicam que a ação do EGF sobre o controle da transcrição do PHLDAl pode ser influenciada por estas três vias de sinalização especialmente nos tratamentos por $2 \mathrm{~h}$. 


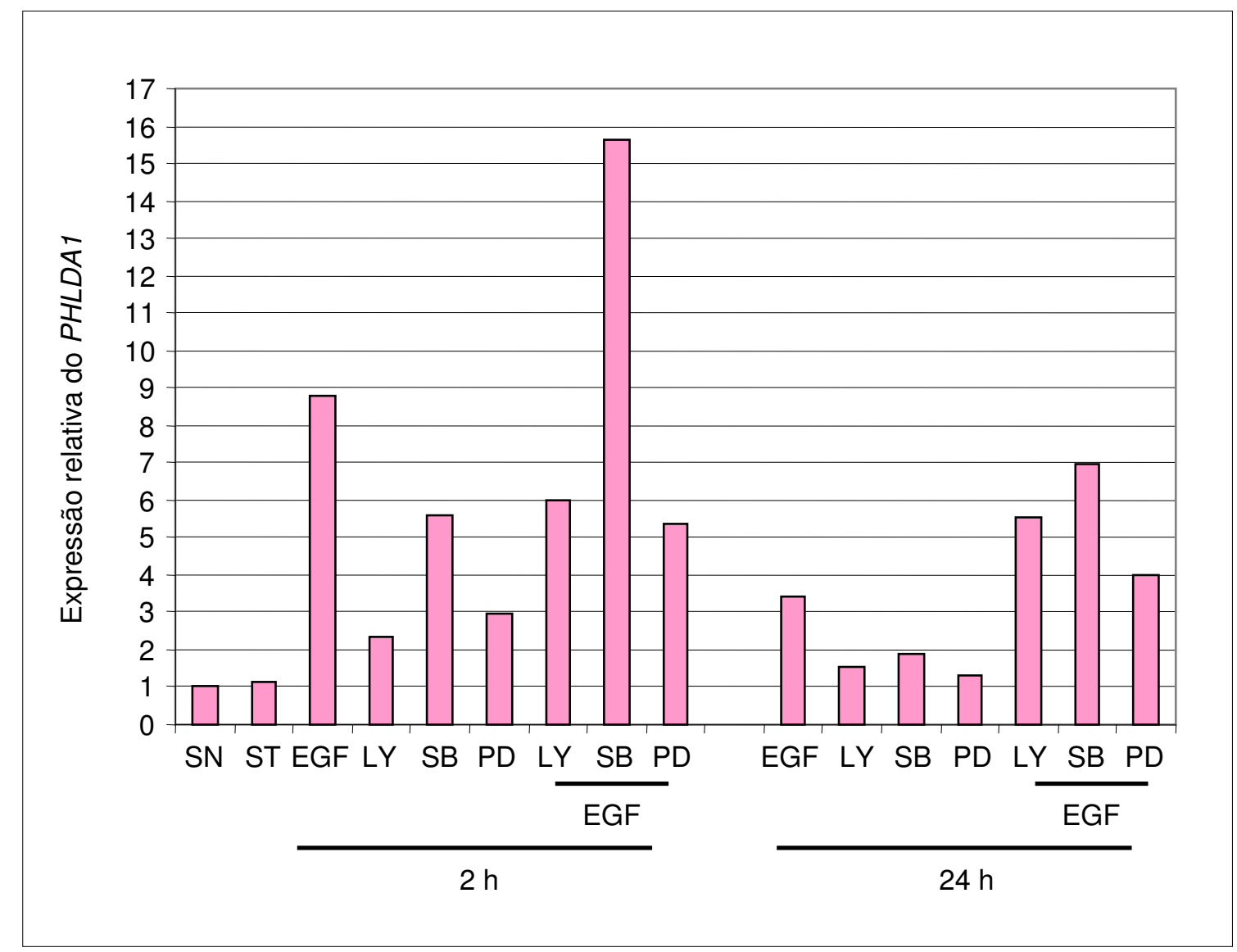

Figura 22. Efeito do EGF (fator de crescimento epidermal), LY (LY 294002), SB (SB 202190) e PD (PD 98059) na expressão relativa do gene PHLDA1 nas células MCF-7. A expressão relativa foi determinada por Real Time PCR. SN, Soro Normal (células mantidas em soro fetal bovino); ST, Soro Tratado (células mantidas em soro fetal bovino tratado com carvão dextrana por $48 \mathrm{~h}$ antes do início dos tratamentos). As barras representam a expressão relativa do gene PHLDAl após os diferentes tratamentos em relação às células mantidas em SN. 
4.1.4 Efeito do 17ß-estradiol (E2), EGF, ICI 182,780 e PD 98059 na expressão das proteínas PAWR, PHLDA1 P-ER (S118), P-ERK1/2 e P-p38 MAPK

O efeito do E2, EGF, ICI 182,780 e PD 98059 foi analisado somente para a proteína PHLDA1, pois ainda não foi possível padronizar as condições do anticorpo para análise da proteína PAWR.

Como pode ser observado na figura 23 , não houve variação da expressão da proteína PHLDA1 nas células MCF-7 mantidas em SN em relação às mantidas em ST enquanto os tratamentos com E2-6 h, EGF-2 h e EGF-24 h promoveram um aumento de 3,8; 3,0 e 2,7 vezes, respectivamente, na expressão desta proteína. Este resultado mostra que o efeito do E2 e do EGF sobre a transcrição do PHLDAl reflete também na expressão da proteína correspondente.

Outro dado interessante observado neste ensaio é que na presença do inibidor PD 98059 (via ERK1/2) o EGF não conseguiu promover o aumento da expressão da proteína PHLDA1 observado nos tratamentos com EGF-2 h e $24 \mathrm{~h}$ isoladamente. Este dado confirmou, de certa forma, o que foi observado no ensaio sobre o efeito dos inibidores na expressão do gene PHLDA1 (Figura 22) onde, no tratamento com PD + EGF-2h a expressão deste gene foi menor em relação ao tratamento com EGF-2h isoladamente. Nos ensaios de $24 \mathrm{~h}$ a expressão do gene PHLDAl se manteve semelhante nos tratamentos com EGF e PD + EGF. Este resultado indica que a via ERK1/2 é uma das vias pela qual o EGF modula a expressão de PHLDA1.

A análise da expressão das proteínas P-ERK1/2 e P-p38 MAPK pode ser observada na figura 24. A proteína P-ERK apresentou um aumento de expressão nos tratamentos com E2-6 h (2,8 vezes) e EGF-2 h (1,7 vez) em relação às células mantidas em ST. No tratamento PD + EGF-2 h observou-se uma diminuição da expressão da proteína PERK em relação ao tratamento com EGF-2 h enquanto que no tratamento PD + EGF-24 h a expressão desta proteína continuou semelhante ao tratamento com EGF-24 h isoladamente. A proteína P-p38 MAPK, por sua vez, apresentou um aumento de cerca de 2,0 vezes na sua expressão nos tratamentos com EGF-2 h e EGF-24 h em relação às células mantidas em ST (Figura 24). É interessante notar que os tratamentos utilizando o inibidor da via do ERK1/2 (PD + EGF-2 h e 24 h) reduziram significantemente a expressão da P-p38 MAPK em relação aos respectivos tratamentos com EGF.

A expressão da proteína ER fosforilada na serina 118 aumentou cerca de 1,5 vez nos tratamentos com E2-24 h e EGF-24 h em relação às células mantidas em ST (Figura 


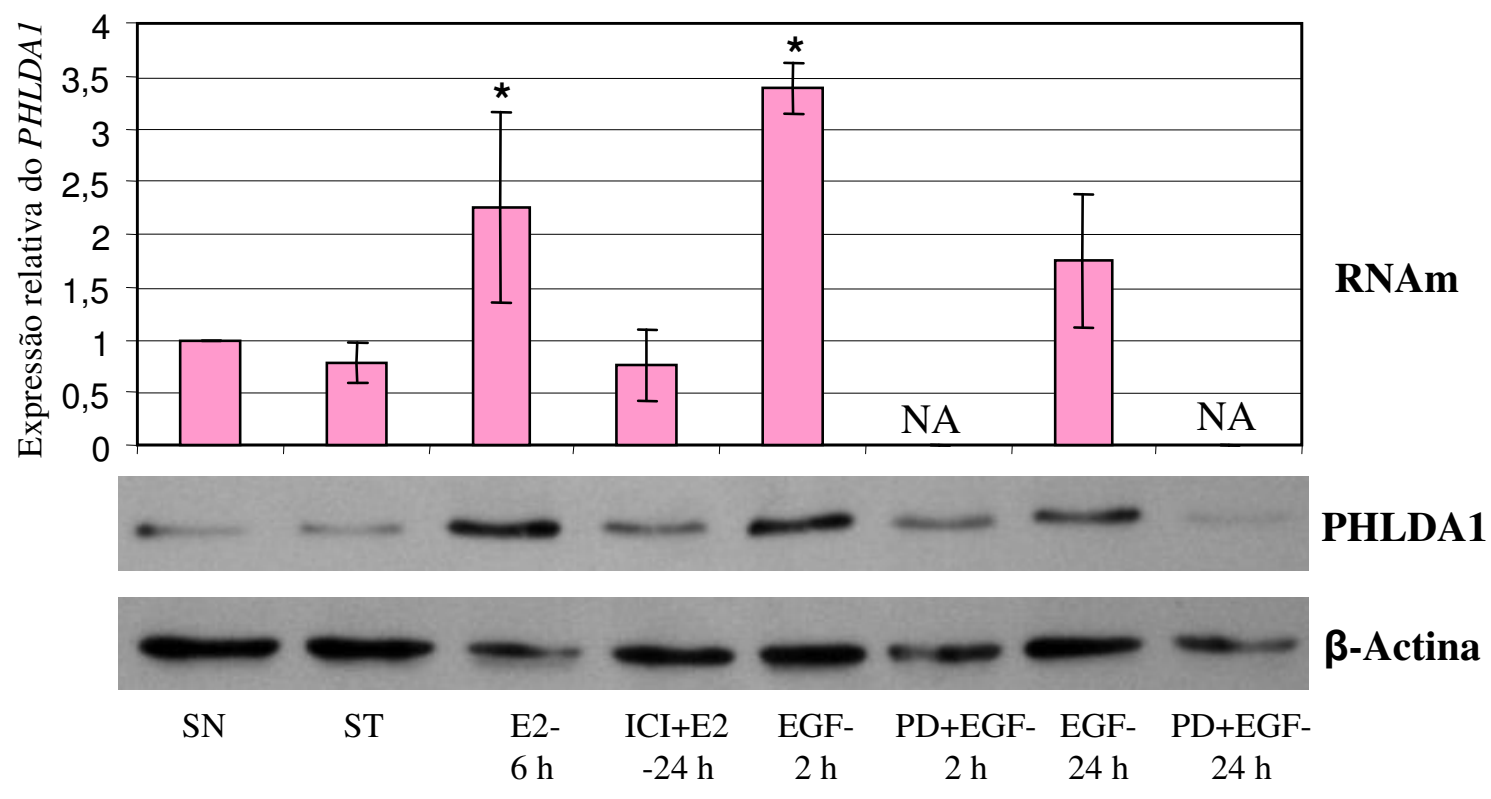

Figura 23. Efeito do E2 (17ß-estradiol), ICI (ICI 182,780), EGF (fator de crescimento epidermal) e PD (PD98059) na expressão relativa do gene (RNAm) e da proteína PHLDA1 nas células MCF-7. A expressão gênica foi determinada por Real Time PCR e a expressão protéica por western blot. SN, Soro Normal (células mantidas em soro fetal bovino); ST, Soro Tratado (células mantidas em soro fetal bovino tratado com carvão dextrana por $48 \mathrm{~h}$ antes do início dos tratamentos); NA, amostras não analisadas por Real Time PCR; *, p $\leq 0,05$ em relação ao ST. A expressão da $\beta$-actina foi utilizada para normalização da massa. 


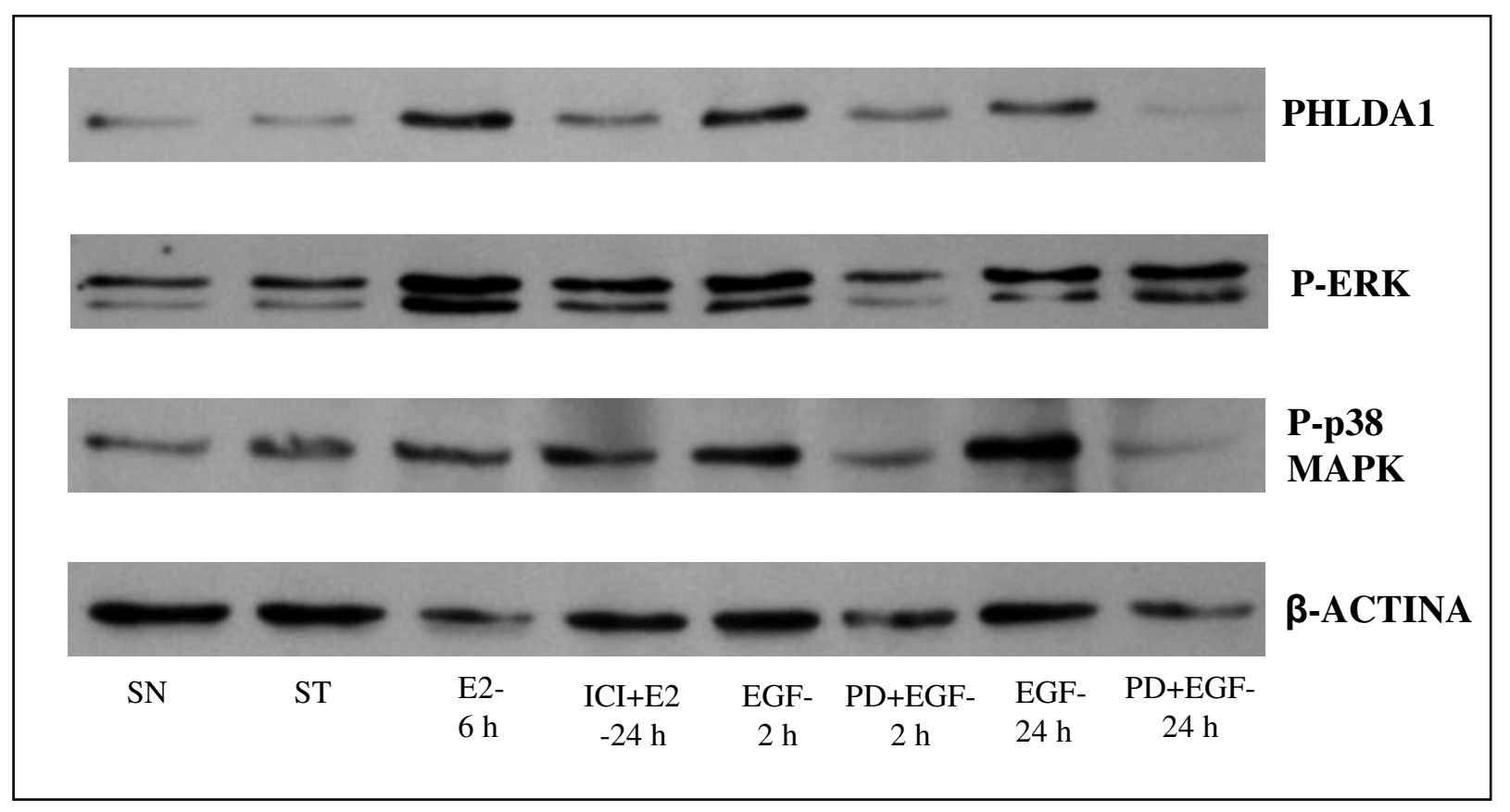

Figura 24. Efeito do E2 (17ß-estradiol), ICI (ICI 182,780), EGF (fator de crescimento epidermal) e PD (PD98059) na expressão das proteínas PHLDA1, P-ERK e P-p38 MAPK nas células MCF-7. A expressão protéica foi determinada por western blot. SN, Soro Normal (células mantidas em soro fetal bovino); ST, Soro Tratado (células mantidas em soro fetal bovino tratado com carvão dextrana por $48 \mathrm{~h}$ antes do início dos tratamentos). A expressão da $\beta$ actina foi utilizada para normalização da massa. 
25). Nos tratamentos com ICI-24 h, ICI + E2-24 h e ICI + EGF-24 h a expressão do p-ER (S118) foi semelhante entre eles e cerca de 1,5 vez menor em relação ao ST e 1,8 vez menor em relação aos tratamentos com E2 e EGF isoladamente. No tratamento com PD + EGF-24 h não foi observada a expressão da proteína P-ER (S118) o que é indicativo de que a via ERK1/2 é uma das vias pela qual o EGF promove a ativação do ER.

\subsubsection{Supressão da expressão do gene ER por RNA de interferência}

\subsubsection{Supressão da expressão do gene $E R \alpha$ por siRNA inserido em vetor de expressão}

As células MCF-7 transfectadas com o vetor de expressão contendo o siRNA para o gene ER $\alpha$ estão em processo de seleção dos clones transfectados. Por este motivo, a análise da eficiência do silenciamento gênico e protéico promovido por este siRNA ainda não foi realizada.

\subsubsection{Supressão da expressão do gene $E R \alpha$ utilizando siRNA transiente}

Resultados representativos da eficiência do silenciamento do gene ER $\alpha$ nas células MCF-7 utilizando o siRNA transiente estão representados na figura 26.

A análise por Real Time PCR (Figura 26 A) mostrou que nas células transfectadas com o siRNA para o ER $\alpha$ a expressão do respectivo gene diminuiu 3,0 vezes em relação às células transfectadas com o siRNA controle. A densitometria das bandas obtidas por western blot (Figura 26 B) mostrou que a expressão da proteína ER $\alpha$ diminuiu $63 \%$ nas células transfectadas com o siRNA $\mathrm{ER} \alpha$ quando comparada às células transfectadas com o siRNA controle. Dados da literatura indicam que uma redução de, no mínimo, 70 \% na expressão da proteína alvo após silenciamento por siRNA seria a porcentagem ideal para dar continuidade aos experimentos.

A expressão dos genes $P A W R$ e PHLDA1 (Figura 27) nas células transfectadas com este siRNA também foi analisada por Real Time PCR. Como pode ser observado, a expressão do gene $P A W R$ diminuiu cerca de 2,0 vezes nas células transfectadas com o siRNA $E R \alpha$ enquanto a expressão do gene PHLDAl praticamente não sofreu alteração nas células transfectadas com o siRNA para o $E R \alpha$ em relação ao siRNA controle.

Assim como observado nos tratamentos com ICI-24 h, era esperado que a transfecção das células com siRNA para o ER $\alpha$ promovesse o aumento da expressão do 


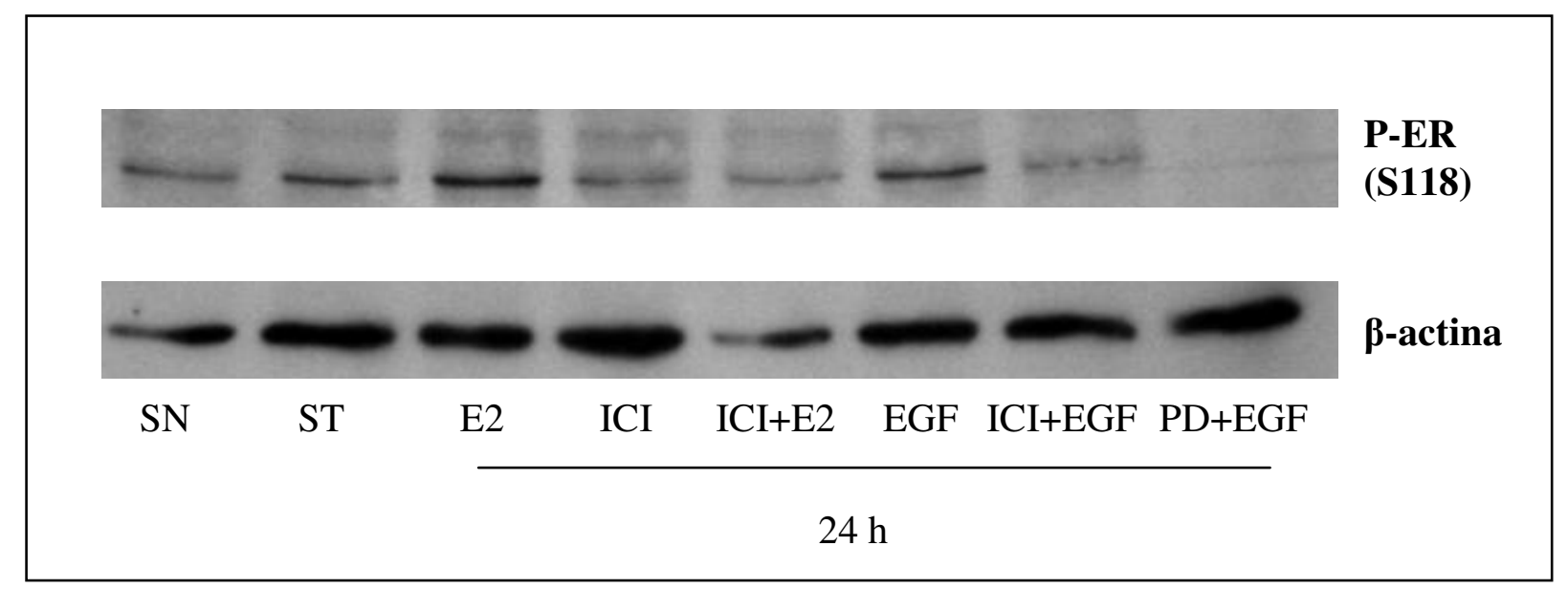

Figura 25. Efeito do E2 (17ß-estradiol), ICI (ICI 182,780), EGF (fator de crescimento epidermal) e PD (PD98059) na expressão da proteína P-ER (S118) nas células MCF-7. A expressão protéica foi determinada por western blot. SN, Soro Normal (células mantidas em soro fetal bovino); ST, Soro Tratado (células mantidas em soro fetal bovino tratado com carvão dextrana por $48 \mathrm{~h}$ antes do início dos tratamentos). A expressão da $\beta$-actina foi utilizada para normalização da massa. 
A

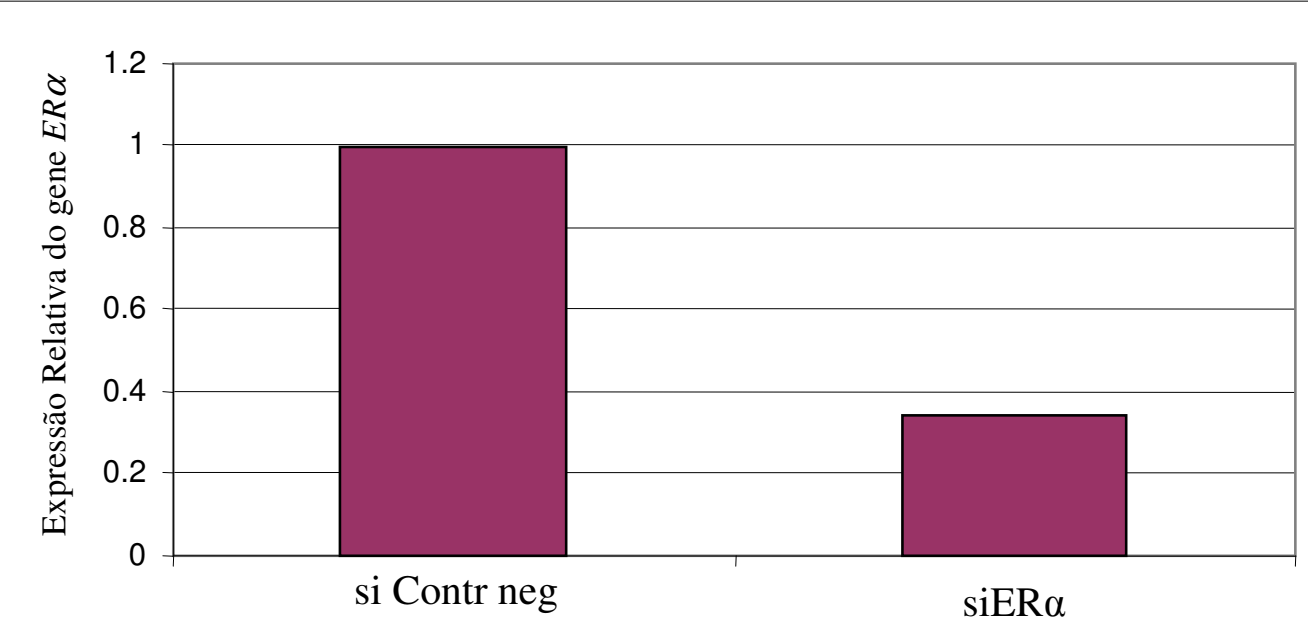

B

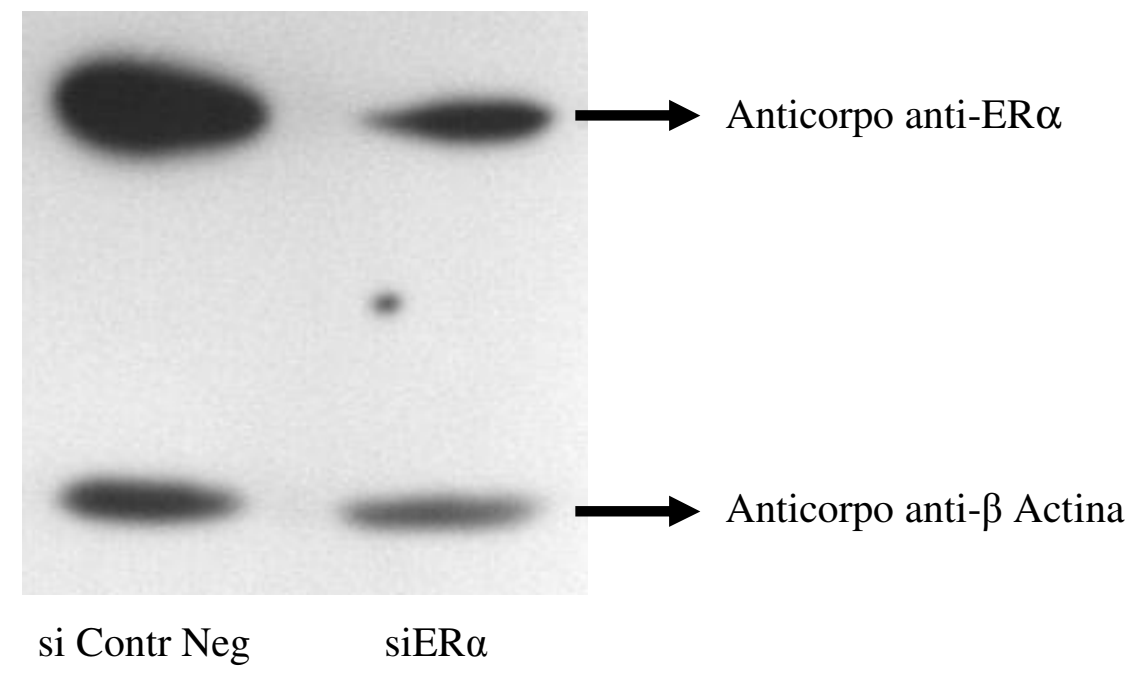

Figura 26. Expressão do gene $E R \alpha$ (A) e da proteína ERa (B) após a supressão da expressão do referido gene utilizando o siRNA transiente nas células MCF-7. si Contr Neg, Controle Negativo (células MCF-7 transfectadas com o siRNA transiente para controle negativo); siER $\alpha$, células MCF-7 transfectadas com o siRNA transiente para o gene ER $\alpha$. Em (A) a expressão gênica relativa foi determinada por Real Time PCR. Em (B) a expressão protéica foi determinada por western blot. 


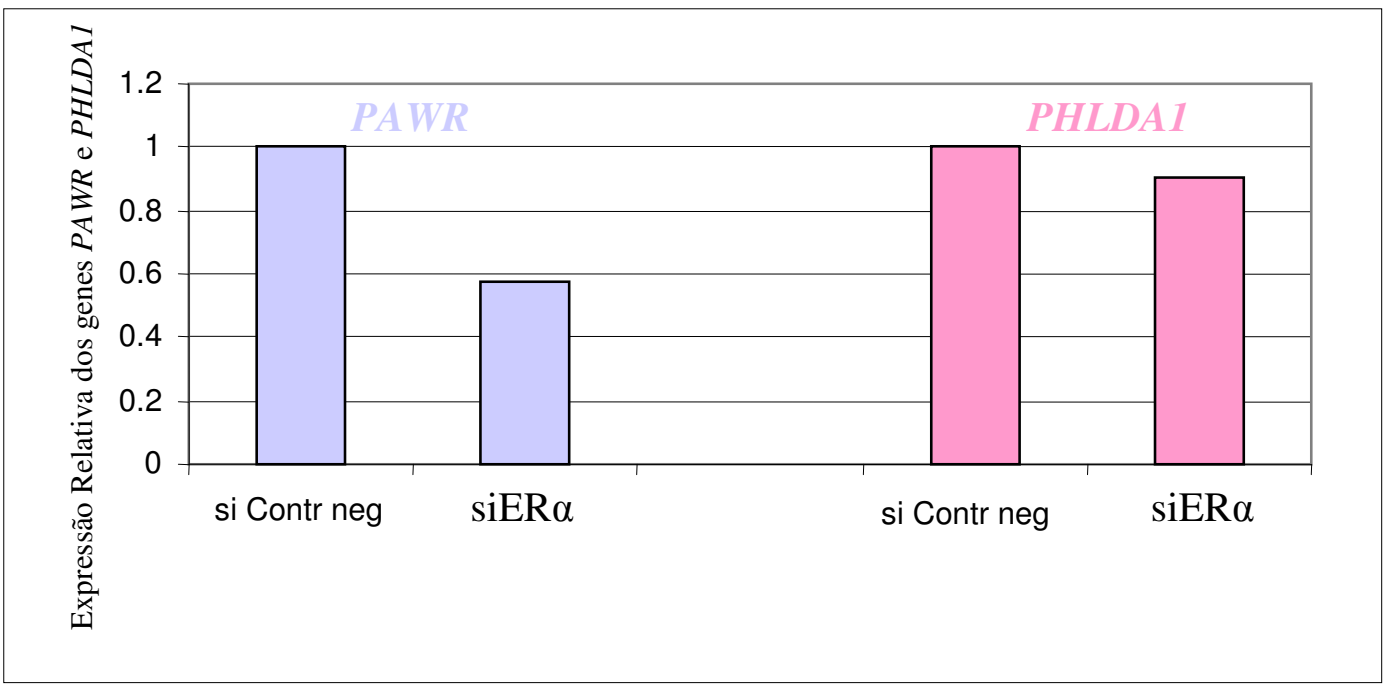

Figura 27. Expressão dos genes $P A W R$ e $P H L D A 1$ após supressão da expressão do ER $\alpha$ utilizando o siRNA transiente nas células MCF-7. A expressão relativa foi determinada por Real Time PCR. si Contr Neg, células MCF-7 transfectadas com o siRNA transiente para controle negativo; siER $\alpha$, células MCF-7 transfectadas com o siRNA transiente para o gene $E R \alpha$. 
PAWR mas o que foi observado é que a expressão deste gene diminuiu cerca de duas vezes nas células transfectadas. Levando-se em consideração que, após a transfecção com o siRNA $E R \alpha$, as células foram mantidas em SN - e não em ST como no caso dos ensaios com ICI 182,780 - é possível que fatores, não adsorvidos pelo carvão dextrana, presentes no soro estejam regulando a expressão do $P A W R$. Este resultado é mais um indício da possível interação entre as vias de sinalização dos estrógenos e fatores de crescimento no controle da transcrição do $P A W R$.

Os ensaios de Real Time PCR e western blot para o experimento no qual as células transfectadas com o siRNA transiente foram mantidas em SN e ST ainda não foram realizados.

\subsection{Efeito do EGF e do ICI 182,780 na expressão dos genes $P A W R$ e $P H L D A 1$ utilizando a linhagem celular MDA-MB-231}

Este ensaio utilizando a linhagem celular MDA-MB-231 teve por objetivo analisar o efeito do EGF e do ICI na expressão dos genes $P A W R$ e $P H L D A 1$ em células que não expressam o ER.

Como pode ser observado na figura 28 não houve variação significativa da expressão do gene $P A W R$ nas células mantidas em ST em relação às células cultivadas em $\mathrm{SN}$. O tratamento com EGF por $2 \mathrm{~h}$ promoveu um pequeno, porém, significativo aumento $(1,32 \pm 0,1 \mathrm{vez} ; \mathrm{p}=0,005)$ na expressão deste gene enquanto o tratamento por $24 \mathrm{~h}$ conduziu a uma diminuição de 2,3 vezes $( \pm 0,08 ; \mathrm{p}<0,001)$ na expressão do $P A W R$. O tratamento com ICI-24 h manteve a expressão do $P A W R$ semelhante à observada nas células mantidas em ST, enquanto o tratamento com ICI + EGF-24 h promoveu uma diminuição de expressão semelhante à observada no tratamento EGF-24 h.

Estes resultados mostram que na ausência do ER o ICI 182,780 não interfere na expressão do $P A W R$ e que o EGF promove uma diminuição significativa da expressão do PAWR diferente do observado na linhagem ER-positiva (MCF-7) onde verificou-se somente uma tendência de diminuição da sua expressão após o tratamento com EGF-24 h. Este resultado é mais um indício da existência de uma interação entre as vias de sinalização do E2 e do EGF no controle da transcrição do PAWR.

O efeito do EGF e do ICI 182,780 na expressão do gene PHLDAl está representado na figura 29 onde pode-se observar que não houve variação significativa da expressão do PHLDAl nas células mantidas em ST em relação às cultivadas em $\mathrm{SN}$. O 


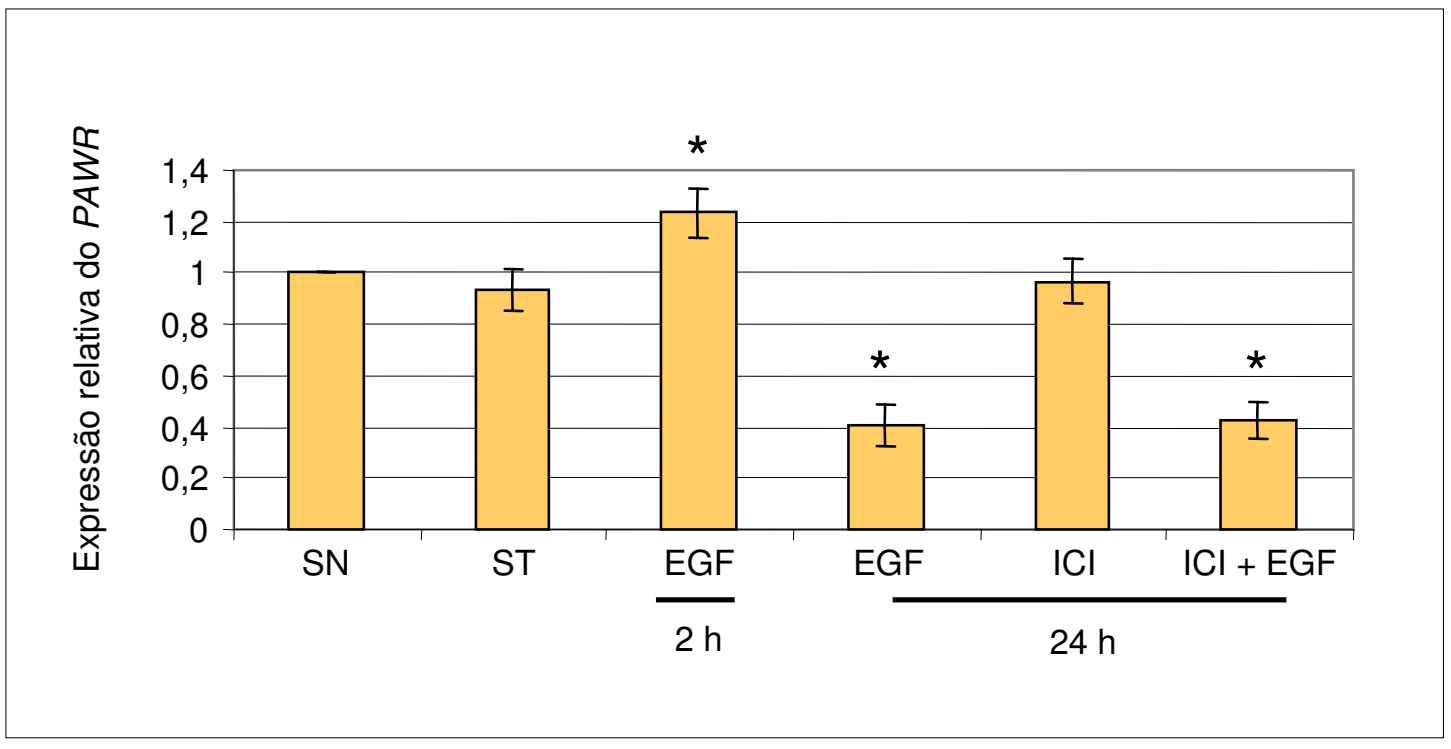

Figura 28. Efeito do EGF (fator de crescimento epidermal) e do ICI (ICI 182,780) na expressão relativa do gene $P A W R$ nas células MDA-MB-231. A expressão relativa foi determinada por Real Time PCR. SN, Soro Normal (células mantidas em soro fetal bovino); ST, Soro Tratado (células mantidas em soro fetal bovino tratado com carvão dextrana por $48 \mathrm{~h}$ antes do início dos tratamentos); *, $\mathrm{p} \leq 0,05$ em relação ao ST. As barras representam a média e o desvio padrão de três experimentos tendo como referência as células mantidas em SN. 


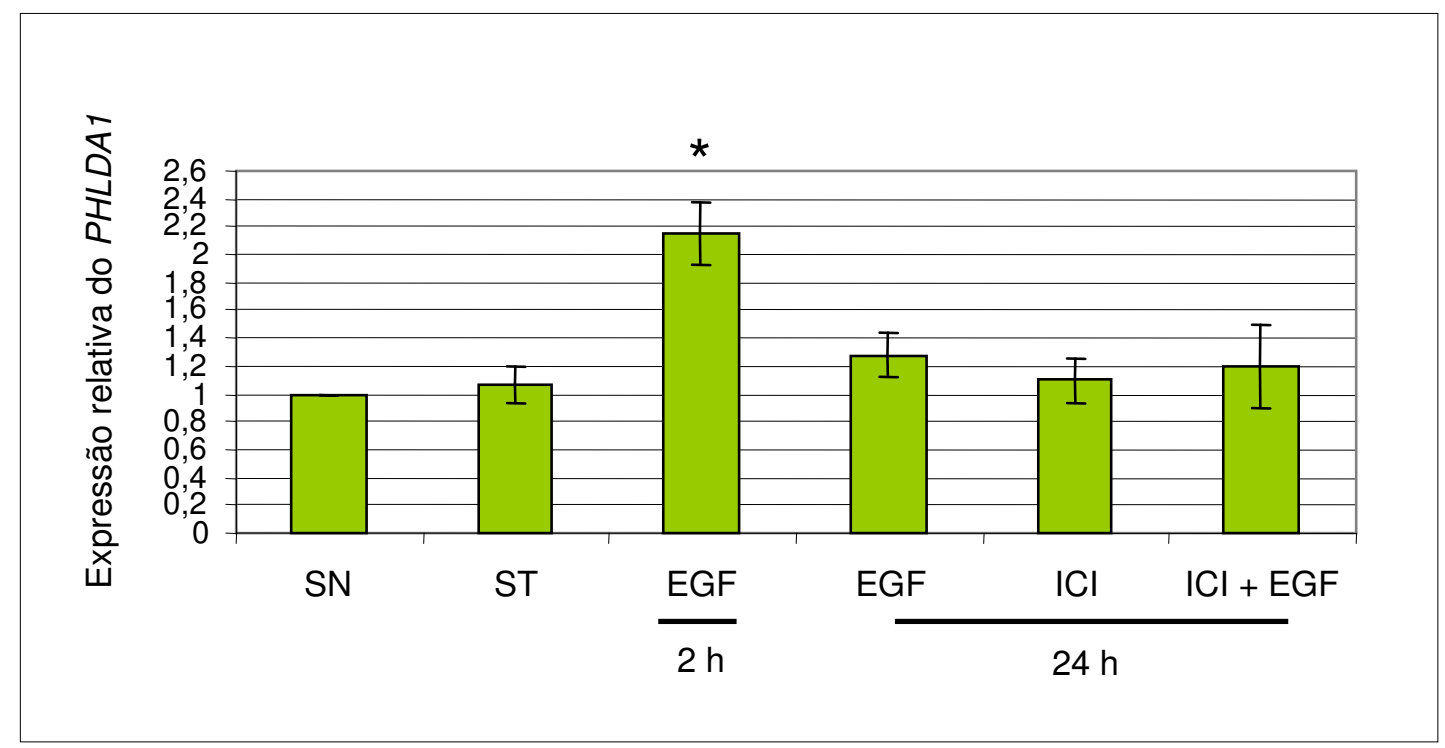

Figura 29. Efeito do EGF (fator de crescimento epidermal) e do ICI (ICI 182,780) na expressão relativa do gene PHLDA1 nas células MDA-MB-231. A expressão relativa foi determinada por Real Time PCR. SN, Soro Normal (células mantidas em soro fetal bovino); ST, Soro Tratado (células mantidas em soro fetal bovino tratado com carvão dextrana por $48 \mathrm{~h}$ antes do início dos tratamentos); *, p $\leq 0,05$ em relação ao ST. As barras representam a média e o desvio padrão de três experimentos tendo como referência as células mantidas em SN. 
tratamento com EGF-2 h promoveu um aumento de 2,0 vezes $( \pm 0,23 ; \mathrm{p}<0,001)$ na expressão deste gene enquanto os tratamentos por $24 \mathrm{~h}$ mantiveram a expressão do PHLDAl semelhante à observada nas células mantidas em ST. É interessante salientar que, assim como observado na linhagem ER-positiva MCF-7, o tratamento com EGF-2 h foi o que promoveu um aumento significativo na expressão do PHLDAl enquanto o tratamento com ICI + EGF24 h manteve a expressão deste gene semelhante ao tratamento com EGF-24 h isoladamente, indicando que o efeito do EGF no controle da transcrição deste gene é independente do ER. 


\section{DISCUSSÃO}

A interação entre as vias de sinalização dos estrógenos e fatores de crescimento aumenta a capacidade de sinalização de ambas as vias e está relacionada à proliferação das células tumorais e à aquisição de resistência ao tratamento hormonal (ARPINO et al., 2008). Assim, o melhor entendimento desta interação e a identificação de genes regulados por ambas as vias pode conduzir ao desenvolvimento de terapias cada vez mais eficazes e específicas para as pacientes com câncer de mama.

No presente trabalho, investigou-se a ocorrência de interação entre as vias de sinalização do E2 e do EGF na regulação da expressão de dois genes relacionados ao processo de apoptose: PAWR e PHLDA1. Conforme revisto por Hanahan e Weinberg (2000) a resistência a apoptose é uma capacidade adquirida pela maioria, ou talvez por todos, os tipos de câncer. Embora a exata função biológica e bioquímica destes genes não esteja totalmente definida, estudos descrevem a ocorrência de alterações na expressão de PAWR em tumores renais (COOK et al., 1999), melanomas (LUCAS et al., 2001), carcinomas endometriais (MORENO-BUENO et al., 2007), tumores pancreáticos (AHMED et al., 2008) e em tumores de próstata (FERNANDEZ-MARCOS et al., 2009). Alterações na expressão de PHLDA1 foram descritas em melanomas (NEEF et al., 2002) e em tumores de mama (NAGAI et al., 2007).

Estudo prévio realizado por nosso grupo, mostrou que as células MCF-7 expostas ao 17ß-estradiol (E2) apresentam um aumento de 2,0 vezes ou mais na expressão do PHLDA1 sendo que o tratamento destas células com ICI 182, 780 inibe completamente este efeito (Marchiori; Casolari; Nagai, 2008). No presente trabalho, o E2 induziu a expressão do PHLDA1, nas células ER-positivas MCF-7, em 2 h, 6 h e 24 h de tratamento enquanto o prétratamento das células com ICI 182,780 seguido pela adição do E2 manteve a expressão deste gene semelhante aos tratamentos com ICI 182,780 isoladamente. Em adição, o tratamento com EGF-2h promoveu um aumento de cerca de 3,0 vezes na expressão do PHLDA1 sendo que os tratamentos com ICI + EGF não promoveram variação significativa da sua expressão em relação aos respectivos tratamentos com EGF.

Na linhagem celular ER-negativa MDA-MB-231 o tratamento com EGF-2h promoveu um aumento significativo na expressão do PHLDAl, enquanto o tratamento com ICI + EGF-24 h manteve a expressão deste gene semelhante ao tratamento com EGF-24 h isoladamente assim como observado na linhagem ER-positiva MCF-7. É interessante comentar, que no presente estudo, verificou-se que a linhagem MDA-MB-231 apresenta uma 
expressão endógena de PHLDA1 maior em relação às células MCF-7 corroborando a observação feita por Hoeflich et al. (2009) em um ensaio de microarray avaliando 50 linhagens celulares de câncer de mama.

Estes resultados indicam que o efeito do E2 sobre a transcrição do gene PHLDA1 deve ocorrer predominantemente via ER e que o efeito do EGF é independente da presença do ER.

A ação de outro fator de crescimento sobre o controle positivo da expressão de PHLDA1 foi mostrado por Toyoshima et al. (2004) e por Casolari (2008). No primeiro estudo observou-se que, em células NIH-3T3 (fibroblastos de camundongo) apresentando aumento de expressão de IGF-1R, o IGF-1 promoveu o aumento de expressão do PHLDA1. A supressão da expressão de PHLDA1, por sua vez, inibiu o efeito anti-apoptótico do IGF-1 nestas células quando cultivadas na ausência de soro. Neste modelo, portanto, a expressão de PHLDA1 está relacionada à sobrevivência celular. Casolari (2008) mostrou que, nas células MCF-7, o IGF-1 promoveu o aumento de expressão de PHLDAl após 1,5 h de tratamento sendo que após 24 h de tratamento observou-se a diminuição da expressão deste transcrito.

A seguir, foi realizada a análise da expressão da proteína PHLDA1 nas células MCF-7 submetidas aos diferentes tratamentos. Os resultados obtidos revelaram o aumento da expressão desta proteína nos tratamentos com E2 e EGF mostrando que o efeito destes fatores sobre a transcrição do PHLDAl reflete também na expressão da proteína correspondente. Casolari (2008) também observou correspondência entre a expressão do transcrito e da proteína PHLDA1 nas células MCF-7 após 1,5h de tratamento com IGF-1. Entretanto, o papel biológico da variação da expressão da proteína PHLDA1 precisa ser melhor investigado. Um trabalho realizado por nosso grupo, utilizando a técnica de tissue microarray, mostrou que a diminuição da expressão da proteína PHLDA1 está associada à progressão do câncer de mama (NAGAI et al., 2007). Este mesmo estudo mostrou uma relação entre a expressão do PHLDA1 e do ER nos tumores de mama de forma que, as pacientes PHLDA1-/ERapresentaram o pior prognóstico enquanto entre as pacientes PHLDA1+, as que apresentaram tumores ER-negativos tiveram um prognóstico mais favorável quando comparadas às pacientes ER-positivas. Os eventos biológicos relacionados ao comportamento clínico mais favorável entre os tumores PHLDA1+/ER- são complexos e requerem investigação tendo em vista que os tumores ER-positivos são normalmente menos agressivos que os tumores ERnegativos (SHEIKH et al., 1994; LEMIEUX e FUQUA, 1996; HAYASHI et al., 2003).

Quanto às vias de sinalização envolvidas no efeito dos fatores de crescimento sobre a expressão de PHLDA1, Toyoshima et al. (2004) mostraram que a via de sinalização 
pela qual o IGF-1 promove o aumento de expressão desta proteína nas células NIH-3T3 apresentando aumento de expressão de IGF-1R é a p38 MAPK sendo que as vias ERK, JNK e PI3K não estão envolvidas nesta regulação. Segundo Oberst et al. (2008), na linhagem celular de mama HMEC16 transformada com vetores de expressão mutantes para o gene H-Ras, o aumento de expressão da proteína PHLDA1 é mediado pela ativação de ERK independentemente da ativação de EGFR e está correlacionado à proliferação celular independente de ancoragem. A supressão da expressão desta proteína, por sua vez, promove um aumento da ativação da via de ERK bem como um aumento da proliferação celular independente de ancoragem.

A via ERK1/2 é ativada por mitógenos e fatores de crescimento (PEARSON et al., 2001). Os resultados obtidos neste estudo mostraram que a proteína P-ERK1/2, assim como a proteína PHLDA1, está mais expressa tanto no tratamento com EGF-2 h como no tratamento com E2-6 h. O aumento da expressão de P-ERK promovido pelo E2 remete ao modelo proposto por Arpino et al. (2008) no qual a ativação das formas do ER presentes na membrana citoplasmática e no citoplasma e sua interação com os receptores tirosina-quinase (como o EGFR e o IGFR) ativa as vias de sinalização destes receptores, entre elas as vias ERK1/2 e AKT. Os sinais de fosforilação provenientes da ativação destas vias de sinalização podem, por sua vez, influenciar a atividade do ER nuclear e de outros fatores de transcrição na regulação gênica.

Quando as células MCF-7 foram submetidas ao pré-tratamento com o PD 98059 (inibidor da via ERK1/2) seguido pela adição de EGF-2h observou-se uma diminuição da expressão da proteína P-ERK1/2 em relação ao tratamento com EGF-2 h. Já no tratamento PD + EGF-24 h a expressão desta proteína continuou semelhante ao tratamento com EGF-24h isoladamente. Este dado pode ser explicado pelo fato do PD 98059 ser metabolizado ao longo das $24 \mathrm{~h}$ e, consequentemente, perder a capacidade de inibir a via (POWROZEK e MILLER, 2009). Além disso, conforme descrito por Oberst et al. (2008), a ativação persistente de ERK promove o aumento da expressão de PHLDA1 que, por sua vez, atua como um regulador negativo da ativação de ERK e da proliferação celular independente de ancoragem. Embora as células MCF-7 tenham crescimento dependente de ancoragem, o que se observa é a diminuição da expressão de PHLDA1 no tratamento com PD + EGF-24 h. Essa diminuição da expressão de PHLDA1 aliada a possível metabolização do PD 98059 podem ser os fatores responsáveis pelo aumento da ativação de ERK1/2 no tratamento PD + EGF-24 h.

Oberst et al. (2008) utilizaram a transfecção de vetores de expressão com mutações no gene H-Ras para transformar as células epiteliais de mama HMEC16. Neste 
processo foram obtidos mutantes com capacidade de crescimento dependente e outros com crescimento independente de ancoragem. Nas células com crescimento independente de ancoragem é que foram observadas as maiores diferenças na expressão e na atividade de PHLDA1 de forma que a supressão da expressão desta proteína promoveu um aumento da proliferação independente de ancoragem. Este dado condiz com o modelo experimental de Hossain et al. (2003) no qual, em células endoteliais vasculares, a indução da expressão da proteína PHLDA1 induziu anoikis (apoptose por perda de adesão).

A MCF-7, por sua vez, é uma linhagem celular já transformada obtida a partir da efusão pleural de uma paciente com câncer mama (SOULE et al., 1973). Assim, nestas células a variação da expressão de PHLDA1 pode estar relacionada à progressão do câncer de mama através de um mecanismo intrínseco de controle do crescimento.

A proteína p38 MAPK fosforilada, apresentou aumento de cerca de 2,0 vezes na sua expressão nos tratamentos com EGF por 2 h e 24 h. É interessante notar que os tratamentos utilizando o inibidor da via ERK1/2 (PD + EGF-2 h e 24 h) reduziram significantemente a expressão da P-p38 MAPK em relação aos respectivos tratamentos com EGF.

Conforme revisto por Pearson et al. (2001) as MAPKs podem ser ativadas por diversos estímulos mas, em geral, ERK1 e ERK2 são ativadas por fatores de crescimento e mitógenos enquanto as p38 MAPKs $(\alpha / \beta / \gamma / \delta)$ são mais responsivas ao estresse ambiental e às citocinas inflamatórias. Entretanto, diversos estudos têm mostrado a ação das p38 MAPKs nos processos de diferenciação, proliferação, sobrevivência e migração celulares (NEBREDA e PORRAS, 2000; SAFINA; VANDETTE; BAKIN, 2007). Morooka e Nishida (1998) observaram que a diferenciação neuronal das células PC12 (derivadas de um tumor neuroendócrino das glândulas adrenais de rato) depende da ativação permanente de ERK ou p38 MAPK e da ativação transiente da via que não está ativada permanentemente. A ativação permanente de p38 MAPK somente promoveu a diferenciação eficiente dos neuritos (axônios e dendritos conjuntamente) quando combinada com a estimulação por EGF, que por sua vez, promoveu a ativação transiente de ERK e p38. Utilizando a mesma linhagem celular, Wu et al. (2004) mostraram que a p38 MAPK media os efeitos anti-apoptóticos do IGF-1. Toyoshima et al. (2004) sugeriram o envolvimento da p38 MAPK na sobrevivência celular induzida pela ação do IGF-1 sobre a expressão de PHLDA1 nas células NIH-3T3.

Em células tumorais de mama, Lei et al. (2007) mostraram que a sinalização autócrina via TGF- $\beta$ inibe a apoptose nas células MCF-7 através do aumento da fosforilação de ERK e da diminuição da ativação de p38 MAPK. Nas células MDA-MB-231, por sua vez, 
a migração celular mediada por TGF- $\beta$ depende da ativação de três MAPKs: ERK, p38MAPK e JNK (SAFINA; VANDETTE; BAKIN, 2007).

Novos estudos são necessários para caracterizar o efeito da inibição da via ERK1/2 sobre a via p38 MAPK no modelo experimental utilizado neste trabalho.

Complementando o estudo iniciado durante o mestrado, o presente trabalho confirmou o efeito do ST no aumento e do E2 na diminuição da expressão do gene PAWR. Estes achados corroboram estudos já publicados que mostram que o PAWR é induzido, exclusivamente, por estímulos apoptóticos, entre eles a retirada de fatores de crescimento (EL-GUENDY e RANGNEKAR, 2003) aqui representada pela manutenção das células em ST. Além disso, Chan et al. (1999), utilizando cultura de neurônios embrionários provenientes do hipocampo de rato, mostraram que o tratamento destas células com E2 promove a diminuição da expressão do PAWR mesmo após a retirada de fatores tróficos (tais como o FGF, IGF e NGF) considerando-se que a retirada destes fatores está relacionada à indução do processo apoptótico e, portanto, ao aumento da expressão deste gene.

No presente estudo, observou-se que as células tratadas com ICI-24 h apresentaram um aumento de 2,5 vezes na expressão de $P A W R$ enquanto o tratamento com ICI + E2-24 h promoveu uma diminuição significativa da expressão deste gene em relação ao tratamento com ICI-24 h.

O grande aumento de expressão observado no tratamento com ICI por $24 \mathrm{~h} \mathrm{em}$ relação às células mantidas em ST pode ser devido ao fato de que, no ensaio com ST, o ER presente nas células pode ser ativado pela sinalização proveniente de outras vias que, por sua vez, são ativadas por fatores de soro que não podem ser adsorvidos pelo carvão dextrana. Após o tratamento com ICI-24h o ER é inibido e, como conseqüência, os fatores presentes no soro não conseguem atuar via ER e a expressão deste gene é então desbloqueada. Dados da literatura mostram que o ICI 182,780, por si só, é capaz de regular positivamente a expressão de alguns genes como por exemplo os genes TNFRl (SMOLNIKAR, et al., 2000) e Bcl-2 (LAM et al., 2008) nas células MCF-7, o gene $C R H$ nas células JEG-3 (coriocarcinoma de placenta) (NI et al., 2002) e os genes IL12 e RYK nas células DU145 (carcinoma de próstata) (LEUNG et al., 2006). Entretanto, este efeito do ICI sobre a expressão gênica deve ser dependente do contexto celular já que nas células MDA-MB-231, o ICI não interfere na expressão de $P A W R$ conforme será comentado adiante.

No tratamento com ICI + E2- 24 h observou-se uma diminuição significativa da expressão deste gene em relação às células tratadas somente com o ICI-24 h. Dados do laboratório mostram que, o pré-tratamento das células por $1 \mathrm{~h}$ com ICI 182,780 antes da 
adição do hormônio promove uma diminuição na expressão da proteína ER semelhante à observada nas células tratadas com ICI-24 h (CASOLARI, 2008). Sendo assim, a diminuição de expressão observada no tratamento ICI + E2-24 h em relação ao tratamento com ICI-24 h pode ser devido ao fato de que o E2 adicionado ao meio de cultura das células é capaz de reprimir a expressão do $P A W R$ pela interação com outras vias de sinalização, embora esta repressão seja menos eficiente do que a observada no tratamento com E2-24 h isoladamente, onde tem-se alta expressão do ER. Este resultado indica que, embora o efeito do E2 sobre a expressão de $P A W R$ ocorra predominantemente via ER, uma parte deste efeito está relacionada à interação do E2 com outras vias de sinalização.

Uma outra evidência da existência de interação entre as vias de sinalização do E2 e do EGF no controle da transcrição do $P A W R$ foi observada no ensaio no qual o tratamento com EGF-24 h promoveu uma redução, porém não significativa, na expressão deste gene enquanto o tratamento com ICI + EGF-24 h promoveu um aumento da expressão de PAWR em relação ao tratamento com EGF-24 h e uma diminuição em relação ao tratamento com ICI-24 h. Isso mostra que quando o ER é inibido pelo ICI, o EGF é capaz de reprimir a expressão do $P A W R$, porém com uma eficiência menor quando comparada ao tratamento com EGF-24 h nas células mantidas em ST, situação na qual o ER está presente.

Nas células MDA-MB-231 não houve variação significativa da expressão do gene PAWR entre as células mantidas em SN, ST e ICI já que esta linhagem celular é ERnegativa. $\mathrm{O}$ tratamento com EGF por $2 \mathrm{~h}$ promoveu um aumento na expressão deste gene enquanto o tratamento por $24 \mathrm{~h}$ conduziu a uma diminuição significativa na expressão do $P A W R$ a qual não foi alterada no tratamento com ICI + EGF-24 h.

A diferença no efeito do EGF observada entre as células MDA-MB-231 (ERnegativa) e MCF-7 (ER-positiva) condiz com o perfil de expressão gênica dessas linhagens. Assim como os tumores de mama podem ser classificados em três subtipos: luminais (tipicamente ER-postivos), tumores HER2-positivos e tumores tipo-basal (ER-, HER2- e PRnegativos, porém EGFR-positivos), as células MCF-7 e MDA-MB-231 são classificadas nos subtipos luminal e basal, respectivamente (HOEFLICH et al., 2009). Dados da literatura mostram que as células MDA-MB-231 expressam cerca de 8,0 vezes mais EGFR que as células MCF-7 (CAI et al., 2008). Além disso, o fato de que os tratamentos realizados em ambas as linhagens ocorrem nas células cultivadas em ST leva a diferenças de intensidade de resposta nas duas linhagens. Como visto anteriormente, nas células MCF-7 (ER-positivas) a manutenção das células em ST promove um aumento significativo da expressão de $P A W R$ enquanto que nas células MDA-MB-231 (ER-negativas) não há variação na expressão deste 
gene entre as células mantidas em SN e ST. Dados obtidos a partir dos experimentos realizados neste estudo mostraram que as células MDA-MB-231 e MCF-7, cultivadas em SN, apresentam expressão semelhante de $P A W R$.

$\mathrm{O}$ aumento significativo da expressão de $P A W R$ observado no tratamento com EGF-2 $\mathrm{h}$ nas células MDA-MB-231 seguido pela diminuição significativa em $24 \mathrm{~h}$ de tratamento pode ser um reflexo da maior expressão de EGFR aliada à menor expressão de $P A W R$ em relação às células MCF-7 mantidas em ST. Já na linhagem MCF-7, a qual apresenta menor expressão de EGFR e um aumento significativo na expressão do $P A W R$ nas células mantidas em ST, o EGF-2 h não consegue promover uma variação na expressão deste gene. É interessante relembrar que nas células MCF-7 submetidas ao pré-tratamento com ICI e, portanto com uma menor expressão do ER, seguido pela adição de EGF-24 h, o EGF consegue diminuir significativamente a expressão de $P A W R$ em relação ao tratamento com ICI-24 h porém, não consegue retomar a expressão observada no tratamento com EGF-24 h isoladamente. Estes resultados sugerem, portanto, que parte do efeito do EGF sobre a transcrição do $P A W R$ nas células MCF-7 ocorre pela interação com a via do ER.

Para confirmar que o efeito do EGF sobre a expressão do PAWR sofre influência da via do ER, analisou-se a fosforilação do ER $\alpha$ na serina (S) 118 tendo em vista que, segundo dados da literatura, o ER $\alpha$ é predominantemente fosforilado na S-118 em resposta à ligação do E2 e na S-118 e S-167 em resposta a ativação da via MAPK (LANNIGAN, 2003). Neste experimento observou-se um aumento na expressão da proteína P-ERa (S-118) nos tratamentos com E2 e EGF, sendo que nos tratamentos com ICI + E2 e ICI + EGF observou-se uma diminuição da expressão desta proteína em relação aos tratamentos com E2 e EGF isoladamente bem como em relação ao ST. Quando a via ERK1/2 foi inibida pelo tratamento das células com PD 98059 os níveis de P-ERa (S-118) foram indetectáveis mesmo na presença do EGF-24 h, mostrando que esta via de sinalização é importante no processo de fosforilação do ER $\alpha$ pelo EGF.

O efeito contrário dos mitógenos (como o E2) e fatores de crescimento (como o EGF) sobre a expressão de dois genes, teoricamente, pró-apoptóticos não está bem compreendido. Apenas um trabalho na literatura mostra a ação do PHLDA1 sobre o controle da proliferação de células mamárias transformadas (OBERST et al., 2008). Já em fibroblastos de camundongos, foi mostrada a ação deste gene na inibição da apoptose (TOYOSHIMA et al., 2004). A diminuição da expressão do PAWR tem sido correlacionada ao desenvolvimento de diversos tipos de tumores. Entretanto, até o momento, nenhum estudo sobre a função do PAWR na tumorigênese da mama foi publicado. 
Alguns modelos sobre o mecanismo de ação do PAWR no processo apoptótico têm sido propostos. De modo geral, pode-se dizer que o $P A W R$ é induzido, exclusivamente, por estímulos apoptóticos tais como: retirada de fatores de crescimento, fator de necrose tumoral (TNF), radiação ionizante, elevação dos níveis intracelulares de cálcio (ELGUENDY e RANGNEKAR, 2003), e que o aumento de sua expressão é suficiente para promover a apoptose em linhagens celulares de tumores de próstata e de mama hormônioindependentes, enquanto que nas linhagens normais e de tumores hormônio-dependentes a ação apoptótica do $P A W R$ só ocorre na presença de um segundo sinal apoptótico (ELGUENDY et al., 2003; GURUMURTHY e RANGNEKAR, 2004). Em adição, a translocação de PAWR para o núcleo é um evento essencial para a apoptose mediada por este gene (GOSWAMI et al., 2005).

Gurumurthy et al. (2005) propuseram que a atividade de PKA, a qual se apresenta constitutivamente elevada em diversas células tumorais, promove a fosforilação de PAWR na T-155. O PAWR assim fosforilado transloca para o núcleo onde inibe a via NF-кB e, consequentemente, induz a apoptose. Já nas células normais a atividade de PKA é relativamente baixa e, portanto, a fosforilação de PAWR também é menor. Isso explicaria a maior sensibilidade de algumas células tumorais a apoptose mediada por PAWR. Entretanto, em outras células tumorais o PAWR deve estar inativo por algum mecanismo. Goswami et al. (2005) e Goswami; Ranganathan; Rangnekar (2006), propuseram que a fosforilação de PAWR por PKA não induz a apoptose quando PAWR é também fosforilado por Akt1. De acordo com este modelo, a elevada atividade de Akt1 em alguns tumores - devido à perda da função do gene supressor de tumor PTEN, à ativação de PI3-K e à ativação de oncogenes promove a fosforilação de PAWR. Esta fosforilação por Akt1 permite a ligação da proteína 14-3-3 a qual, por sua vez, impede a translocação de PAWR para o núcleo. Esse mecanismo foi observado por Lee et al. (2007) em linhagens celulares de carcinoma naso-faríngeo e por Goswami et al. (2005) em linhagens normais e tumorais de próstata.

Em tumores pancreáticos, Ahmed et al. (2008) mostraram uma correlação entre a diminuição da expressão de PAWR e a presença de mutação em K-Ras. Em adição, Joshi et al. (2008) mostraram, em um modelo de camundongos, que a não-expressão de PAWR aumenta significativamente a formação de carcinomas de pulmão induzidos por Ras. Estes estudos corroboram os trabalhos de Qiu et al. (1999) e Barradas et al. (1999) nos quais a diminuição da expressão de PAWR induzida por Ras é um evento fundamental para a progressão do tumor. Além disso, estes dois grupos mostraram que a inibição da expressão de PAWR ocorre via fosforilação de ERK1/2. Sendo assim, Qiu et al. (1999) levantaram a 
hipótese de que o PAWR inibe a expressão de ERK1/2 diminuindo assim a disponibilidade de ERK para ser fosforilado no processo de transformação celular. Joshi et al. (2008), por sua vez, mostraram que o PAWR controla negativamente a via de sinalização PKC $\zeta$ culminando com a inibição da ativação de AKT.

No modelo proposto por Goswami et al. (2005) a ativação de Akt é que impediria a ação anti-apoptótica de PAWR; no modelo proposto por Joshi et al. (2008)

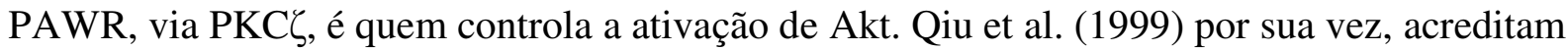
que PAWR inibe a expressão de ERK1/2. Além disso, foi recentemente descrito por Burikhanov et al. (2009), uma função extracelular para a proteína PAWR. De acordo com estes autores esta proteína é secretada espontaneamente por células humanas, normais e tumorais, e camundongos PAWR transgênicos secretam esta proteína em seu soro. A proteína PAWR extracelular, por sua vez, induz apoptose em células tumorais via FADD/caspase8/caspase-3. Desse modo, corroborando as observações de Affar et al. (2006), pode-se dizer que a atividade pró-apoptótica de PAWR é dependente do contexto celular. Esta mesma observação pode se estendida para a atividade exercida pelo PHLDA1.

Em resumo, os resultados obtidos neste estudo mostram que o efeito do E2 sobre o controle da transcrição dos genes $P A W R$ e $P H L D A 1$, ocorre predominantemente via ER. Para o controle negativo da transcrição de $P A W R$, existe uma interação entre as vias de sinalização do E2 e do EGF sendo que a via ERK1/2 é importante no processo de fosforilação do ER $\alpha$ pelo EGF. O efeito positivo do EGF no aumento da expressão de PHLDA1 é mediado pelas vias ERK1/2 e p38 MAPK. 


\section{CONCLUSÕES}

- O EGF e o 17ß-estradiol controlam negativamente a expressão do PAWR e positivamente a expressão do PHLDA1.

- Na linhagem celular MDA-MB-231, o EGF controla positivamente a expressão de PAWR após $2 \mathrm{~h}$ de tratamento e negativamente após $24 \mathrm{~h}$.

- Existe interação entre as vias de sinalização do E2 e do EGF para o controle da transcrição do $P A W R$.

- Na regulação da expressão do PHLDA1 pelo EGF duas vias de sinalização são ativadas: ERK1/2 e p38 MAPK.

- Na regulação da expressão do PAWR, o EGF fosforila o ER $\alpha$ na S-118 via ERK1/2. 


\section{REFERÊNCIAS BIBLIOGRÁFICAS*}

AFFAR, E. B.; LUKE, M. P-S.; GAY, F.; CALVO, D.; SUI, G.; WEISS, R. S.; LI, E.; SHI, Y. Targeted Ablation of Par-4 Reveals a Cell Type-Specific Susceptibility to ApoptosisInducing Agents. Cancer Res., v. 66, p. 3456-62, 2006.

AHMED, M. M.; SHELDON, D.; FRUITWALA, M. A.; VENKATASUBBARAO, K.; LEE, E. Y.; GUPTA, S.; WOOD, C.; MOHIUDDIN, M.; STRODEL, W. E. Downregulation of PAR-4, a pro-apoptotic gene, in pancreatic tumors harboring K-ras mutation. Int. J. Cancer, v. 122, p. 63-70, 2008.

ANDERSON, E. The role of Oestrogen and Progesterone Receptors in Human Mammary Development and Tumorigenesis. Breast Cancer Res., v. 4, p. 197-201, 2002.

ARANDA, A.; PASCUAL, A. Nuclear Hormone Receptors and Gene Expression. Physiol. Rev., v. 81, p. 1269-304, 2001.

ARMELIN, H. A. O papel de hormônios e fatores de crescimento no controle da proliferação celular em mamíferos. Anais do simpósio sobre cultura de células. Publicação ACIESP, n. 10, p. 41-63, 1978.

ARMSTRONG, D. K.; ISAACS, J. T.; OTTAVIANO, Y. L.; DAVIDSON, N. E. Programmed Cell Death in an Estrogen-Independent Human Breast Cancer Cell Line, MDAMB-468. Cancer Res., v. 52, p. 3418-24, 1992.

ARONSON, K. Alcohol: a Recently Identified Risk Factor for Breast Cancer. C. M. A. J., v. 168, p. 1147-8, 2003.

ARPINO, G.; WIECHMANN, L.; OSBORNE, C. K.; SCHIFF, R. Crosstalk between the estrogen receptor and the HER tyrosine kinase receptor family: molecular mechanism and clinical implications for endocrine therapy resistance. Endocr. Rev., v. 29, p. 217-33, 2008.

AMERICAN TYPE CULTURE COLLECTION. Available from: <http://www.atcc.org>. Acesso em: 22 Abr. 2008.

AUMAIS, J. P.; LEE, H. S.; DeGANNE, C.; HORSFORD, J.; WHITE, J. Function of Directly Repeated Half-Sites as Response Elements for Steroid Hormone Receptors. J. Biol. Chem., v.271, p. 12568-77, 1996.

BARCUS, M. E.; FERREIRA-GONZALEZ, A; BULLER, A, M.; WILKINSON, D. S.; GARRET, C. T. Genetic Changes in Solid Tumors. Semin. Surg. Oncol., v. 18, p. 358-70, 2000 .

BARRADAS, M.; MONJAS, A.; DIAZ-MECO, M. T.; SERRANO, M.; MOSCAT, J. The downregulation of the pro-apoptotic protein Par-4 is critical for Ras-induced survival and tumor progression. EMBO J., v. 18, p. 6362-9, 1999. 
BERRY, M.; NUNEZ, A. M.; CHAMBON, P. Estrogen-Responsive Element of the Human pS2 gene is an Imperfectly Palindromic Sequence. Proc. Natl. Acad. Sci. U.S.A., v. 86, p. 1218-22, 1989.

BERTUCCI, F.; VIENS, P.; HINGAMP, P.; NASSER, V.; HOULGATTE, R.; BIRNBAUM, D. Breast Cancer Revisited Using DNA Array-Based Gene Expression Profiling. Int. J. Cancer, v. 103, p. 565-71, 2003.

BESSA, S. A. Efeito do 17ß-Estradiol na Expressão dos Genes $H N R P K, P A W R, R B B P 4$, ATRX e TLN1 na Linhagem Celular de Câncer de Mama MCF-7. 2004. 127 f. Dissertação (Mestrado em Biotecnologia) - Pós-graduação Interunidades em Biotecnologia USP/Instituto Butantan/IPT, São Paulo, 2004.

BIECHE I.; NOGUES, C.; PARADIS, V.; OLIVI, M.; BEDOSSA, P.; LIDEREAU, R.; VIDAUD, M. Quantitation of hTERT Gene Expression in Sporadic Breast Tumors with a Real-Time Reverse Transcription-Polymerase Chain Reaction Assay. Clin. Cancer Res., v. 6, p. 452-9, 2000.

BIÈCHE, I.; LIDEREAU, R. Genetic Alterations in Breast Cancer. Genes Chromosomes Cancer, v. 14, p. 227-51, 1995.

BOHEN, S. P.; KRALLI, A.; YAMAMOTO, K. R. Hold'em and Fold'em: Chaperones and Signal Transduction. Science, v. 268, p. 130304, 1995.

BOMSZTYK, K.; SEUNINGEN, I. V.; SUZUKI, H.; DENISENKO, O.; OSSTROWSKI, J. Diverse Molecular Interactions of the hnRNP K Protein. F.E.B.S. Lett., v. 403, p. 113-5, 1997.

BRAGA FILHO, J. F. Dosagens Hormonais em Ginecologia e Obstetrícia. Disponível em: $<$ http://www.bragafilho.com.br>. Acesso em: 19 Out. 2008.

BRENTANI, M. M.; FELDMAN, J. Receptores Esteroídicos em Neoplasias HormônioDependentes. In: ABRÃO, F. S. Tratado de Oncologia Genital e Mamária. São Paulo: Editora Roca, 1995. Cap. 9, p.95-108.

BRIEGER, A.; BOEHRER, S.; SCHAAF, S.; NOWAK, D.; RUTHARDT, M.; KIM, S. Z.; ATADJA, P.; HOELZER, D.; MITROU, P. S.; WEIDMANN, E.; CHOW, K. U. In bcr-ablpositive myeloid cells resistant to conventional chemotherapeutic agents, expression of Par-4 increases sensitivity to imatinib (STI571) and histone deacetylase-inhibitors. Biochem. Pharmacol., v. 68, p. 85-93, 2004.

BURIKHANOV, R.; ZHAO, Y.; GOSWAMI, A.; QIU, S.; SCHWARZE, S. R.; RANGNEKAR, V. M.The Tumor Suppressor Par-4 Activates an Extrinsic Pathway for Apoptosis. Cell, v. 138, p. 377-88, 2009.

CAILlEAU, R.; YOUNG, R.; OLIVÉ, M.; REEVES Jr.; W. J. Breast Tumor Cell Lines from Pleural Effusions. J. Natl. Cancer Inst., v. 53, p. 661-74, 1974. 
CASOLARI, D.A. Interação entre as vias de sinalização do IGF-I, do ER e da integrina $\boldsymbol{\beta} 1$ na regulação da transcrição dos genes $\boldsymbol{P H L D A 1}$ e $\boldsymbol{P A} \boldsymbol{W} \boldsymbol{R} .2008 .99$ f. Tese (Doutorado em Oncologia) - Pós-graduação em Oncologia da Faculdade de Medicina da Universidade de São Paulo, São Paulo, 2008.

CATO, A. C. B.; NESTL, A.; MINK, S. Rapid Actions of Steroid Receptors in Cellular Signaling Pathways. Sci. S.T.K.E., v. 2002, p. re9.1-11, 2002.

CAVENEE, W. K.; WHITE, R. L. The Genetic Basis of Cancer. Sci. Am., v. 272, p. 72-9, 1995.

CHAN, S. L.; TAMMARIELLO, S. P.; ESTUS, S.; MATTSON, M. Prostate Apoptosis Response-4 Mediates Trophic Factor Withdrawal-Induced Apoptosis of Hippocampal Neurons: Actions Prior to Mitochondrial Dysfunction and Caspase Activation. J. Neurochem., v. 73, p. 502-12, 1999.

CHARPENTIER, A. H.; BEDNAREK, A. K.; DANIEL, R. L.; HAWKINS, K. A.; LAFLIN, K. J.; GADDIS, S.; MacLEOD, M, C.; ALDAZ, C. M. Effects of Estrogen on Global Gene Expression: Identificantion of Novel Targets of Estrogen Action. Cancer Res., v. 60, p. $5977-$ $83,2000$.

CHEN, W. Y.; COLDITZ, G.A. Risk factors and hormone-receptor status: epidemiology, risk-prediction models and treatment implications for breast cancer. Nat. Clin. Pract. Oncol., v. 4, p. 415-23, 2007.

CHOMCZYNSKI, P.; SACCHI, N. Single-Step Method of RNA Isolation by Acid Guanidinium Thiocyanate-Phenol-Chloroform Extraction. Anal. Biochem., v. 162, p. 156-9, 1987.

CITRI, A.; YARDEN, Y. EGF-ERBB Signaling: Towards the Systems Level. Nat. Rev. Mol. Cell. Biol., v. 7, p. 505-16, 2006.

COOK, J.; KRISHNAN, S.; SELLS, S. F.; SHI, Y.; WALTHER, M. M.; LINEHAN, W. M.; SUKHATME, V. P.; WEINSTEIN, M H.; RANGNEKAR, V. M. Decreased Expression of the Protein Par-4 in Renal Cell Carcinoma. Oncogene, v. 18, p. 1205-8, 1999.

COOPER, G. M. Cell Signaling. In: The Cell - A Molecular Approach. 2. ed. Sunderland: Sinauer Associates, 2000. Chapter 13. Available from: <http://www.ncbi.nlm.nih.gov/books/>. Acesso em: 30 Jun. 2008.

COUCH, F. J.; CERHAN, J. R.; VIERKANT, R. A.; GRABRICK, D. M.; THERNEAU, T. M.; PANKRATZ, V. S.; HARTMANN, L. C.; OLSON, J. E.; VACHON, C. M.; SELLERS, T. A. Cigarette Smoking Increases Risk for Breast Cancer in High-Risk Breast Cancer Families. Cancer Epidemiol. Biomarkers Prev., v. 10, p. 327-32, 2001.

COUGHLIN, S. S.; PIPER, M. Genetic Polymorphisms and Risk of Breast Cancer. Cancer Epidemiol. Biomarkers Prev., v. 8, p. 1023-32, 1999. 
CURTIS, S. W.; WASHBURN, Y. SEWALL, C.; DiAUGUSTINE, R.; LINDZEY, J.; COUSE, J. F.; KORACH, K. S. Physicological Coupling of Growth Factor and Steroid Receptor Signaling Pathways: Estrogen Receptor Knockout Mice Lack Estrogen-Like Response to Epidermal Growth Factor. Proc. Natl. Acad. Sci. U.S.A., v. 93, p. 12626-30, 1996.

DANA, S. L.; HOENER, P. A.; WHEELER, D. A.; LAWRENCE, C. B.; McDONNELL, D. P.. Novel Estrogen Response Elements Identified by Genetic Selection in Yeast are Differentially Responsive to Estrogen and Antiestrogens in Mammalian Cells. Mol. Endocrinol., v. 8, p.1193-207, 1994.

DICKSON, R. B.; THOMPSON, E. W.; LIPPMAN, M. E. Regulation of Proliferation, Invasion, and Growth Factor Synthesis in Breast Cancer by Steroids. J. Steroid Biochem. Mol. Biol., v. 37, p. 305-16, 1990.

DOISNEAU-SIXOU, S. F.; SERGIO, C. M.; CARROLL, J. S.; HUI, R.; MUSGROVE, E. A.; SUTHERLAND, R. L. Estrogen and Antiestrogen Regulation of Cell Cycle Progression in Breast Cancer Cells. Endocr. Relat. Cancer, v. 10, p. 179-86, 2003.

DOWSETT, M.; NICHOLSON, RI.; PIETRAS, RJ. Biological characteristics of the pure antiestrogen fulvestrant: overcoming endocrine resistance. Breast Cancer Res. Treat., v. 93, p. S11-8, 2005.

DREYFUSS, G.; MATUNIS, M. J.; PINOL-ROMA, S.; BURD, C. G. hnRNP Proteins and the Biogenesis of mRNA. Annu. Rev. Biochem., v. 62, p. 289-321, 1993.

EASTON, D. F.; BISHOP, D. T.; FORD, D.; CROCKFORD, G. P. Genetic Linkage Analysis in Familial Breast Ovarian Cancer: Results from 214 Families. The Breast Cancer Linkage Consortium. Am. J. Hum. Genet., v. 52, p. 678-701, 1993.

ELBASHIR, S. M.; HARBORTH, J.; LENDECKEL, W.; YALCIN, A.; WEBER, K.; TUSCHL, T. Duplexes of 21-nucleotide RNAs Mediate RNA Interference in Cultured Mammalian Cells. Nature, v. 411, p. 494-98, 2001.

EL-GUENDY, N.; RANGNEKAR, V. M. Apoptosis by Par-4 in Cancer and Neurodegenerative Diseases. Exp. Cell. Res., v. 283, p. 51-66, 2003.

EL-GUENDY, N.; ZHAO, Y.; GURUMURTHY, S.; BURIKHANOV, R.; RANGNEKAR, V. M. Identification of a Unique Core Domain of Par-4 Sufficient for Selective Apoptosis Induction in Cancer Cells. Mol. Cell. Biol., v. 23, p. 5516-25, 2003.

FAN, S.; MENG, Q.; GAO, B.; GROSSMAN, J.; YADEGARI, M.; GOLDBERG, I.D.; ROSEN, E. Alcohol Stimulates Estrogen Receptor Signaling in Human Breast Cancer Cell Lines. Cancer Res., v. 60. p. 5635-9, 2000.

FENG, W.; WEBB, P.; NGUYEN, P.; LIU, X.; LI, J.; KARIN, M.; KUSHNER, P. J. Potentiation of Estrogen Receptor Activation Function 1 (AF-1) by Src/JNK Through a Serine 118-Independent Pathway. Mol. Endocrinol., v. 15, p. 32-45, 2001. 
FENTIMAN, I. S. Future Prospects for the Prevention and Cure of Breast Cancer. Eur. J. Cancer, v. 36, p. 1085-8, 2000.

FERNANDEZ-MARCOS, P. J.; ABU-BAKER, S.; JOSHI, J.; GALVEZ, A. CASTLLA, E. A.; CANÃMERO, M.; COLLADO, M.; SAEZ, C.; MORENO-BUENO, G.; PALACIOS, J.; LEITGES, M.; SERRANO, M.; MOSCAT, J.; DIAZ-MECO, M. T. Simultaneous inactivation of Par-4 and PTEN in vivo leads to synergistic NF- $\kappa$ B activation and invasive prostate carcinoma Proc. Natl. Acad. Sci. U.S.A., v. 106, p. 12962-67, 2009.

FRESHNEY, R. I. Culture of Animal Cells: A Manual of Basic Technique. $3^{\text {rd }}$ ed. New York: John Wiley and Sons, 1993.

GENEAMP $^{\circledR} 5700$ SEQUENCE DETECTION SYSTEM. Nevada: Honebein Associates; California: Craig Sheumaker Design; Gett Multimedia, John Piera. 1 CD-ROM.

GOMES, I.; XIONG, W.; MIKI, T.; ROSNER, M. R. A proline- and glutamine-rich protein promotes apoptosis in neuronal cells. J. Neurochem., v. 73, p. 612-22, 1999.

GOSWAMI, A.; BURIKHANOV, R.; DE THONEL, A.; FUJITA, N.; GOSWAMI, M.; ZHAO, Y.; ERIKSSON, J. E.; TSURUO, T.; RANGNEKAR, V. M. Binding and Phosphorylation of Par-4 by Akt is Essential for Cancer Cell Survival. Mol. Cell, v. 20, p. 3344, 2005.

GOSWAMI, A.; RANGANATHAN, P.; RANGNEKAR, V. M. The Phosphoinositide 3Kinase/Akt1/Par-4 Axis: A Cancer-Selective Therapeutic Target. Cancer Res., v. 55, p. 2889-92, 2006.

GRADISHAR, W. J.; JORDAN, V. C. Hormonal Therapy for Breast Cancer. An Update. Hematol. Oncol. Clin. North Am., v. 13, p. 435-55, 1999.

GURUMURTHY, S.; GOSWAMI, A.; VASUDEVAN, K. M.; RANGNEKAR, V. M. Phosphorylatin of Par-4 by protein kinase A is critical for apoptosis. Mol. Cell. Biol., v. 25, p. 1146-61, 2005.

GURUMURTHY, S.; RANGNEKAR, V. M. Par-4 Inducible Apoptosis in Prostate Cancer Cells. J. Cell. Biochem., v. 91, p. 504-12, 2004.

GUSTAFSSON, J. A.; WARNER, M. Estrogen Receptor $\beta$ in the Breast: Role in Estrogen Responsiveness and Development of Breast Cancer J. Steroid Biochem. Mol. Biol., v. 74, p. 245-8, 2000.

GUYTON, A. C. Fisiologia Humana e Mecanismos das doenças. 5. ed. Rio de Janeiro: Guanabara Koogan, 1993. Capítulo 55: Fisiologia Feminina Antes da Gravidez e os hormônios Femininos.

HALL, J. M.; COUSE, J. F.; KORACH, K. S. The Multifaceted Mechanisms of Stradiol and Estrogen Receptor Signaling. J. Biol. Chem., v. 276, p. 36869-72, 2001. 
HANAHAN, D.; WEINBERG, R. A. The Hallmarks of Cancer. Cell, v. 100, p. 57-70, 2000.

HAYASHI, S. I.; EGUCHI, H.; TANIMOTO, K.; YOSHIDA, T.; OMOTO, Y.; INOUE, A.; YOSIDA, N.; YAMAGUCHI, Y. The Expression and Function of Estrogen Receptor $\alpha$ and $\beta$ in Human Breast Cancer and its Clinical Application. Endocr. Relat. Cancer, v. 10, p. 193202, 2003.

HOEFLICH, K.; O’BRIEN, C.; BOYD, Z.; CAVET, G.; GUERRERO, S.; JUNG, K.; JANUARIO, T.; SAVAGE, H.; PUNNOOSE, E.; TRUONG, T.; ZHOU, W.; BERRY, L.; MURRAY, L.; AMLER, L.; BELVIN, M.; FRIEDMAN, L. S.; LACKNER, M. R. In vivo AntitumorActivity of MEK and Phosphatidylinositol 3-Kinase Inhibitors in Basal-Like Breast Cancer Models. Clin. Cancer Res., v. 15, p. 4649-64, 2009.

HOSSAIN, G. S.; VAN THIENEN, J. V,; WERSTUCK, G. H.; ZHOU, J.; SOOD, S. K.; DICKHOUT, J. G.; DE KONING, A. B.; TANG, D.; WU, D.; FALK, E.; PODDAR, R.; JACOBSEN, D. W.; ZHANG, K.; KAUFMAN, R. J.; AUSTIN, R. C. TDAG51 is induced by homocysteine, promotes detachment-mediated programmed cell death, and contributes to the cevelopment of atherosclerosis in hyperhomocysteinemia. J. Biol. Chem., v. 278, p. 30317 27, 2003.

HOWELL, A. Pure oestrogen antagonists for the treatment of advanced breast cancer. Endocr Relat Cancer, v. 13, p. 689-706, 2006.

HYNES, N. E.; LANE, H. A. ERBB receptors and cancer: the complexity of targeted inhibitors. Nat. Rev. Cancer, v. 5, p. 341-54, 2005.

IGNAR-TROWBRIDGE, D. M.; TENG, C. T.; ROSS, K. A.; PARKER, M. G.; KORACH, K. S.; McLACHLAN, J.A. Peptide Growth Factors Elicit Estrogen Receptor-Dependent Transcriptional Activation of an Estrogen-Responsive Element. Mol. Endocrinol., v. 7, p. 992-8, 1993.

INSTITUTO NACIONAL DO CÂNCER. Ministério da Saúde. Estimativas da Incidência e Mortalidade por Câncer no Brasil. Disponível em: <http://www.inca.gov.br>. Acesso em: 02 Set. 2008.

INGVARSSON, S. Molecular Genetics of Breast Cancer Progression. Semin. Cancer Biol., v. 9, p. 277-88, 1999.

IVANOVA, T.; MENDEZ, P.; GARCIA-SEGURA, L.M.; BEYER, C. Rapid Stimulation of the PI3-Kinase/Akt Signaling Pathway in Developing Midbrain Neurones by Oestrogen. J. Neuroendocrinol., v. 14, p. 73-9, 2002.

JEMAL, A.; SIEGEL, R.; WARD. E.; HAO, Y.; XU, J.; MURRAY, T.; THUN, M. J. Cancer statistics, 2008. CA Cancer J. Clin., v. 58, p. 71-96, 2008.

JORDAN, V. C. The Secrets of Selective Estrogen Receptor Modulation: Cell-Specific Coregulation. Cancer Cell, p. 215-7, 2002. 
JORDAN, V. C.; MacGREGOR SCHAFER, J.; LEVENSON, A. S.; LIU, H.; PEASE, K. M.; SIMONS, L. A., ZAPF, W. Molecular Classification of Estrogens. Cancer Res., v. 61, p. 6619-23, 2001.

JOSHI, J.; FERNANDEZ-MARCOS, P. J.; GALVEZ, A.; RAMARS, A.; LINARES, J. L.; DURAN, A.; PATHROSE, P.; LEITGES, M.; CAÑAMERO, M.; COLLADO, M.; SALAS, C.; SERRANO, M.; MOSCAT, J.; DIAZ-MECO, M. T. Par-4 inhibits Akt and supresses Rasinduced lung tumorigenesis. EMBO J., v. 27, p. 2181-93, 2008.

KATO, S.; SASAKI, H.; SUZAWA, M.; MASUSHIGE, S.; TORA, L.; CHAMBON, P.; GRONEMEYER, H. Widely Spaced, Directly Repeated PuGGTCA Elements Act as Promiscuous Enhancers for Different Classes of Nuclear Receptors. Mol. Cell. Biol., v. 15, p. 5858-67, 1995.

KATO, S.; TORA, L.; YAMAUCHI, J.; MASUSHIGE, S.; BELLARD, M.; CHAMBON, P. A Far Upstream Estrogen Response Element of the Ovalbumin Gene Contains Several HalfPalindromic 5'-TGACC-3' Motifs Acting Synergistically. Cell, v. 86, p. 731-42, 1992.

KATZENELLENBOGEN, B. S.; CHOI, I.; DELAGE-MOURROUX, R.; EDIGER, T. R.; MARTINI, P. G. V.; MONTANO, M.; SUN, J.; WEIS, K.; KATZENELLENBOGEN, J. A. Molecular Mechanisms of Estrogen Action: Selective Ligands and Receptor Pharmacology. J. Steroid Biochem. Mol. Biol., v. 74, p. 279-85, 2000.

KIAN TEE, M.; ROGATSKY, I.; TZAGARAKIS-FOSTER, C.; CVORO, A.; AN, J.; CHRISTY, R. J.; YAMANOTO, K. R.; LEITMAN, D. C. Estradiol and Selective Estrogen Receptor Modulators Differentially Regulate Target Genes with Estrogen Receptors Alpha and Beta. Mol. Biol. Cell, v. 15, p. 1262-72, 2003.

KIMURA, M.; FURUKAWA, T.; ABE, T.; YATSUOKA, T.; YOUSSEF, E. M.; YOKOYAMA, T.; OUYANG, H.; OHNISHI, Y.; SUNAMURA, M.; KOBARI, M.; MATSUNO, S.; HORII, A. Identification of Two Common Regions of Allelic Loss in Chromosome Arm 12q in Human Pancreatic Cancer. Cancer Res., v. 58, p. 2456-60, 1998.

KING, R. J.; WILLIAN L. Estrogen and Progestin Effects in Human Breast Carcinogenesis. Breast Cancer Res. Treat., v. 27, p. 3-15, 1993.

KINOSHITA, Y.; CHEN, S. Induction of Aromatase (CYP19) Expression in Breast Cancer Cells Through a Nongenomic Action of Estrogen Receptor $\alpha$. Cancer Res., v. 63, p. 35460$55,2003$.

KRIEG, P. A. A Laboratory Guide to RNA Isolation, Analysis, and Synthesis. New York: Wiley-Liss, 1996. Chapter 1: RNA Isolation From Cells and Tissues. Chapter 6: RNA Blot Analysis.

KRISTENSEN, V. N.; BORRESEN-DALE, A. L. Molecular Epidemiology of Breast Cancer: Genetic Variation in Steroid Hormone Metabolism. Mutat. Res., v. 462, p. 323-33, 2000. 
KUKOC-ZIVOJNOV, N.; PUCCETTI, E.; CHOW, K. U.; BERGMANN, M.; RUTHARDT, M.; HOELZER, D.; MITROU, P. S.; WEIDMANN, E.; BOEHRER, S. Prostate apoptosis response gene-4 (par-4) abrogates the survival function of p185(BCR-ABL) in hematopoietic cells. Exp. Hematol., v. 32, p. 649-56, 2004.

KUMAR, R.; WANG, R. A.; MAZUMDAR, A.; TALUKDER, A. H.; MANDAL, M.; YANG, Z.; BAGHERI-YARMAND, R.; SAHIN, A.; HORTOBAGYI, G.; ADAM, L.; BARNES, C. J.; VADLAMUDI, R.K. A naturally occurring MTA1 variant sequesters oestrogen receptor-alpha in the cytoplasm. Nature, v. 418, p. 654-7, 2002.

KUMAR, V.; GREEN, S.; STACK, G.; BERRY, M.; JIN, J. R.; CHAMBON, P. Functional Domains of the Human Estrogen Receptor. Cell, v. 51, p. 941-51, 1987.

KYPRIANOU, N.; ENGLISH, H. F.; DAVIDSON, N. E.; ISAACS, J. T. Programmed Cell Death During Regression of the MCF-7 Human Breast Cancer Following Estrogen Ablation. Cancer Res., v. 51, p. 162-6, 1991.

LAM, L.; HU, X.; AKTARY, Z.; ANDREWS, D. W.; PASDAR, M. Tamoxifen and ICI 182,780 increase Bcl-2 levels and inhibit growth of breast carcinoma cells by modulating PI3K/AKT, ERK and IGF-1R pathways independent of Era. Breast Cancer Res. Treat., 2008. Available from: <http://www.springerlink.com/content/n74745j780521302/>. Acesso em: 10 Set. 2009.

LANNIGAN, D. A. Estrogen receptor phosphorylation. Steroids, v. 68, p. 1-9, 2003.

LAU, J. S.; BAUMEISTER, P.; KIM, E.; ROY, B.; HSIEH, T-Y.; LAI, M.; LEE, A. Heterogeneous Nuclear Ribonucleoproteins as Regulators of Gene Expression Through Interactions With the Human Thymidine Kinase Promoter. J. Biol. Chem., v. 79, p. 395406, 2000.

LEE, J-W.; LEE, K-F.; HSU, H-Y.; HSU, L-P.; SHIH, W-L.; CHU, Y-C.; HSIAO, W-T.; LIU, P-F. Protein expression and intracellular localization of prostate apoptosis response-4 (Par-4) are associated with apoptosis induction in nasopharyngeal carcinoma cell lines. Cancer Lett., v. 257, p. 252-62, 2007.

LEI, X.; YANG, J.; NICHOLS, R. W.; SUN, L. Z. Abrogation of TGFbeta signaling induces apoptosis through the modulation of MAP kinase pathways in breast cancer cells. Exp. Cell Res., v. 313, p. 1687-95, 2007.

LEMIEUX, P.; FUQUA, S. The Role of the Estrogen Receptor in Tumor Progression. J. Steroid Biochem. Mol. Biol., v. 56, p. 87-91, 1996.

LEREBOURS, F.; LIDEREAU, R. Molecular Alterations in Sporadic Breast Cancer. Crit. Rev. Oncol. Hematol., v. 44, p. 121-41, 2002.

LEUNG,Y. K.; GAO, Y.; LAU, K-M.; ZHANG, X.; HO, S. M. ICI 182,780-Regulated Gene Expression in DU145 Prostate Cancer Cells Is Mediated by Estrogen Receptor-B/NFKB Crosstalk. Neoplasia, v. 8, p. $242-9,2006$. 
LEWIN, B. Genes VII. New York: Oxford University Press, 2000. Chapter 8: Protein Localization.

LI, J. Y.; PLOMANN, M.; BRUNDIN, P. Huntington's disease: a synaptopathy? Trends Mol. Med., v. 9, p. 414-20, 2003.

LICHTNER, R. B. Estrogen/EGF Receptor Interactions in Breast Cancer: Rationale for New Therapeutic Combination Strategies. Biomed. Pharmacother., v. 57, p. 447-51, 2003.

LIN, S. Y.; MAKINO, K.; XIA, W.; MATIN, A.; WEN, Y.; KWONG, K. Y.; BOURGUIGNON, L.; HUNG, M. C. Nuclear localization of EGF receptor and its potential new role as a transcription factor. Nat. Cell Biol., v. 3, p. 802-8, 2001.

LO, H. W.; HSU, S. C.; HUNG, M. C. EGFR signaling pathway in breast cancers: from traditional signal transduction to direct nuclear translocalization. Breast Cancer Res. Treat., v. 95, p. 211-8, 2006.

LO, H. W.; XIA, W.; WEI, Y.; ALI-SEYED, M.; HUANG, S. F.; HUNG, M. C. Novel prognostic value of nuclear epidermal growth factor receptor in breast cancer. Cancer Res., v. 65, p. 338-48, 2005.

LUCAS, T.; PRATSCHER, B.; KRISHNAN, S.; FIND, D.; GUNSBERG, P.; WOLSCHEK, M.; WACHECK, V.; MUSTER, T.; ROMIRER, I.; WOLFF, K.; PEHAMBERGER, H.; EICHLER, H. G.; RANGNEKAR, V. M.; JANSEN, B. Differential Expression Levels of Par4 in Melanoma. Melanoma Res., v. 11, p. 379-83, 2001.

LUNDHOLT B. K.; BRIND, P.; LYKKESFELDT, A. E. Growth Inhibition and Growth Stimulation by Estradiol of Estrogen Receptor Transfected Human Breast Epithelial Cell Lines Involve Different Pathways. Breast Cancer Res. Treat., v. 67, p. 199-214, 2001.

MacGREGOR SCHAFER, J.; LIU, H.; BENTREN, D. J.; ZAPF, J. W.; JORDAN, V. C. Allosteric Silencing of Activating Function 1 in the 4-Hydroxytamoxifen Estrogen Receptor Complex Is Induced by Substituting Glycine for Aspartate at Amino Acid 351. Cancer Res., v. 60 , p. $5097-105,2000$.

MAEHLE, B. O.; TRETLI, S.; SKJAERVEN, R.; THORSEN, T. Premorbid Body Weight and its Relations to Primary Tumour Diameter in Breast Cancer Patients; its Dependence on Estrogen and Progesterone Receptor Status. Breast Cancer Res. Treat., v. 68, p. 159-69, 2001.

MANDAL, M.; VADLAMUDI, R.; NGUYEN, D.; WANG, R-A.; COSTA, L.; BAGHERUYARMAND, R.; MENDELSOHN, J.; KUMAR, R. Growth Factors Regulate Heterogeneous Nuclear Ribonucleoprotein K Expression and Function. J. Biol. Chem., v. 276, p. 9699-704, 2001.

MANNI, A. Hormonal Approaches to the Chemoprevention of Endocrine-Dependent Tumors. Endocr. Relat. Cancer, v. 6, p. 483-5, 1999. 
MARCHIORI, A. C. Efeitos do 17'beta'-estradiol e da laminina na regulação da expressão dos genes $D D E F 2$ e $P H L D A 1$ em linhagens de células derivadas de adenocarcinomas de mama MCF-7 e MDA-MB-231. 2007. 69 f. Dissertação (Mestrado em Oncologia) - Pós-graduação em Oncologia da Faculdade de Medicina da Universidade de São Paulo, 2007.

MARCHIORI, A. C.; CASOLARI, D. A.; NAGAI, M. A. Transcriptional up-regulation of PHLDA1 by 17beta-estradiol in MCF-7 breast cancer cells. Braz. J. Med. Biol. Res., v. 41, p. $579-82,2008$.

McDONNEL, D. P.; NORRIS, J. D. Connections and Regulation of the Human Estrogen Receptor. Science, v. 296, p. 1642-4, 2002.

McPHERSON, K.; STEEL, C. M.; DIXON, J. M. Breast Cancer - Epidemiology, Risk Factors and Genetics. B.M.J, v. 321, p. 624-8, 2000.

MICHELOTTI, E. F.; MICHELOTTI, G. A.; ARONSOHN, A. I.; LEVENS, D. Heterogeneous Nuclear Ribonucleoprotein K is a Transcription Factor. Mol. Cell. Biol., v. 16, p. 2350-60, 1996.

MINCEY, B. A. Genetics and the Management of Women at High Risk for Breast Cancer. Oncologist, v. 8, p. 466-73, 2003.

MITRUNEN, K.; HIRVONEN, A. Molecular Epidemiology of Sporadic Breast Cancer The Role of Polymorphic Genes Involved in Oestrogen Biosynthesis and Metabolism. Mutat. Res., v. 544, p. 9-41, 2003.

MORENO-BUENO, G.; FERNANDEZ-MARCOS, P. J.; COLLADO, M.; TENDERO, M. J.; RODRIGUEZ-PINILLA, S. M.; GARCIA-CAO, I.; HARDISSON, D.; DIAZ-MECO, M. T.; MOSCAT, J.; SERRANO, M.; PALACIOS, J. Inactivation of the Candidate Tumor Supressor Par-4 in Endometrial Cancer. Cancer Res., v. 67, p. 1927-34, 2007.

MOROOKA, T.; NISHIDA, E. Requirement of p38 mitogen-activated protein kinase for neuronal differentiation in PC12 cells. J. Biol. Chem., v. 273, p. 24285-8, 1998.

NAGAI, M. A.; BRENTANI, M. M. Gene expression profiles in breast cancer to identify estrogen receptor target genes. Mini Rev. Med. Chem., v. 8, p. 448-54, 2008.

NAGAI, M. A.; FREGNANI, J. H.; NETTO, M. M.; BRENTANI, M. M.; SOARES, F. A. Down-regulation of PHLDA1 gene expression is associated with breast cancer progression. Breast Cancer Res. Treat., v. 106, p. 49-56, 2007.

NEBREDA, A. R.; PORRAS, A. p38 MAP kinases: beyond the stress response. Trends Biochem. Sci., v. 25, p. 257-60, 2000.

NEEF, R.; KUSKE, M. A.; PRÖLS, E.; JOHNSON, J. P. Identification of the human PHLDA1/TDAG51 gene: down-regulation in metastatic melanoma contributes to apoptosis resistance and growth deregulation. Cancer Res., v. 62, p. 920-9, 2002. 
NI, X.; NICHOLSON, R. C.; KING, B. R.; CHAN, E. C.; READ, M. A.; SMITH, R. Estrogen Represses whereas the Estrogen-Antagonist ICI 182780 Stimulates Placental CRH Gene Expression. J. Clin. Endocrinol. Metab., v. 87, p. 3774-8, 2002.

NICHOLSON, R. I.; HUTCHESON, I. R.; HARPER, M. E.; KNOWLDEN, J. M.; BARROW, D.; McClELLAND, R. A.; JONES, H. E.; WAKELING, A. E.; GEE, J. M. Modulation of epidermal Growth Factor Receptor in Endocrine-Resistant, Oestrogen Receptor-Positive Breast Cancer. Endocr. Relat. Cancer, v. 8, p. 175-82, 2001.

NOGUEIRA, S. M.; APPLING, S. E. Breast Cancer: Genetics, Risks, and Strategies. Clin. Genet., v. 35, p. 663-9, 2000.

NORRIS, J. D.; FAN, D.; KERNER, S. A.; McDONNELL, D. P. Identification of a Third Autonomous Activation Domain within the Human Estrogen Receptor. Mol. Endocrinol., v. 11, p. 747-54, 1997.

NOWELL, P. C. The Clonal Evolution of Tumor Cell Populations. Science, v. 194, p. 23-8, 1976.

OBERST, M. D.; BEBERMAN, S. J.; ZHAO, L.; YIN, J. J.; WARD, Y.; KELLY, K. TDAG51 is an ERK signaling target that opposes ERK-mediated HME16C mammary epithelial cell transformation. B. M. C. Cancer, v. 8, 2008. Available from : <http://www.biomedcentral.com/1471-2407/8/189>. Acesso em: 22 Ago. 2008.

OESTERREICH, S.; FUQUA, W. Tumor Suppressor Genes in Breast Cancer. Endocr. Relat. Cancer, v. 6, p. 405-19, 1999.

OLSEN, A.; TJONNELAND, A.; THOMSEN, B. L.; LOFT, S.; STRIPP, C.; OVERVAD, K.; MOLLER, S.; OLSEN, J. H. Fruits and Vegetables Intake Differentially Affects Estrogen Receptor Negative and Positive Breast Cancer Incidence Rates. J. Nutr., v. 133, p. 2342-7, 2003.

OLSSON, H. Tumour Biology of a Breast Cancer at Last Partly Reflects the Biology of Tissue/Epithelial Cell of Origin at the Time of Initiation - a Hypothesis. J. Steroid Biochem. Mol. Biol., v. 74, p. 345-50, 2000.

OSBORNE, C. K.; SCHIFF, R. Growth Factor Receptor Cross-Talk with Estrogen Receptor as a Mechanism for Tamoxifen Resistance in breast Cancer. Breast, v. 12, p. 362-7, 2003.

OSTARECK-LEDERER. A.; OSTARECK， D. H.; CANS， C.; NEUBAUER， G.; BOMSZTYK, K.; SUPERTI-FURGA, G.; HENTZE, M. W. c-Src-Mediated Phosphorylation of hnRNP K Drives Translational Activation of Specifically Silenced mRNAs. Mol. Cell. Biol., v. 22, p. 4535-43, 2002.

OSTROWSKI, J.; BOMSZTYK, K. Nuclear Shift of hnRNP K Protein in Neoplasms and Other States of Enhanced Cell Proliferation. Br. J. Cancer, v. 89, p. 1493-501, 2003.

PAECH, K.; WEBB, P.; KUIPER, G. G.; NILSSON, S.; GUSTAFSSON, J.; KUSHNER, P. J.; SCANLAN, T. S. Differential Ligand Activation of Estrogen Receptors ER and ER $\beta$ at AP1 Sites. Science, v. 277, p. 1508-10, 1997. 
PAGE FOR PATIENTS. A Message from Preventive Medicine and Your Physician. Prev. Med., v. 31, p. 639-40, 2000.

PAIGE, L. A.; DALE, J. C.; GRON, H.; NORRIS, J. D.; GOTTLIN, E. B.; PADILLA, K. M.; CHANG, C. Y.; BALLAS, L. M.; HAMILTON, P. T.; McDONNELL, D. P.; FOWLKES, D. M. Estrogen Receptor (ER) Modulators Each Induce Distinct Conformational Changes in ER $\alpha$ and ER $\beta$. Proc. Natl. Acad. Sci. U.S.A, v.96, p. 3999-4004, 1999.

PARK, C. G; LEE, S. Y.; KANDALA, G.; LEE, S.Y.; CHOI, Y. A novel gene product that couples TCR signaling to Fas(CD95) expression in activation-induced cell death. Immunity, v. 4, p. 583-91, 1996.

PARL, F. F.; EGAN, K. M.; LI, C.; CROOKE, P. S. Estrogen exposure, metabolism, and enzyme variants in a model for breast cancer risk prediction. Cancer Inform., v. 7, p. 109-21, 2009.

PARUTHIYIL, S.; PARMAR, H.; KEREKATTE, V.; CUNHA, G. R.; FIRESTONE, G. L.; LEITMAN, D. C. Estrogen Receptor $\beta$ Inhibits Human Breast Cancer Cell Proliferation and Tumor Formation by Causing a $\mathrm{G}_{2}$ Cell Cycle Arrest. Cancer Res., v. 64, p. 423-8, 2004.

PEARSON, G.; ROBINSON, F.; BEERS GIBSON, T.; XU, B. E.; KARANDIKAR, M.; BERMAN, K.; COBB, M. H. Mitogen-activated protein (MAP) kinase pathways: regulation and physiological functions. Endocr. Rev., v. 22, p. 153-83, 2001.

PEDRAM, A.; RAZANDI, M.; SAINSON, R. C.; KIM, J. K.; HUGHES, C. C.; LEVIN, E.R. A conserved mechanism for steroid receptor translocation to the plasma membrane. J. Biol. Chem., v. 282, p. 22278-88, 2007.

PERSSON, I. Estrogens in the Causation of Breast, Endometrial and Ovarian Cancers Evidences and Hypotheses from Epidemiological Findings. J. Steroid Biochem. Mol. Biol., v. 74, p. 357-64, 2000.

PICARD, D.; YAMAMOTO, K. Two Signals Mediate Hormone-Dependent Nuclear Localization of the Glucocorticoid Receptor. EMBO J., v.6, p.3333-40, 1987.

PIETRAS, R. J. Interactions between Estrogen and Growth Factor Receptors in Human Breast Cancers and the tumor-Associated Vasculature. Breast J., v. 9, p. 361-73, 2003.

POPESCU, N. C.; ZIMONJIC, D. B. Chromosome and Gene Alterations in Breast Cancer as Markers for Diagnosis and Prognosis as Well as Pathogenetic Targets for Therapy. Am. J. Med. Genet., v. 115, p. 142-9, 2002.

POWROZEK, T.; MILLER, M. W. Ethanol Affects Transforming Growth Factor $\beta 1$-Initiated Signals: Cross-Talking Pathways in the Developing Rat Cerebral Wall. J. Neurosci., v. 29, p. 9521-33, 2009.

PROTOCOL - SYBR Green PCR and RT-PCR Reagents. The Perkin-Elmer Corporation, 1998. p. 1-21. 
QIU, S. G.; KRISHNAN, S.; EL-GUENDY, N.; RANGNEKAR, V. M. Negative regulation of Par-4 by oncogenic Ras is essential for cellular transformation. Oncogene, v. 18, p. 711523, 1999.

RANGNEKAR, V. M. Apoptosis Mediated by a novel Leucine Zipper Protein Par-4. Apoptosis, v. 3, p. 61-6, 1998.

RAZANDI, M.; ALTON, G.; PEDRAM, A.; GHONSHANI, S.; WEBB, P.; LEVIN, E. R. Identification of a structural determinant necessary for the localization and function of estrogen receptor alpha at the plasma membrane. Mol. Cell. Biol., v. 23, p. 1633-46, 2003 a.

RAZANDI, M.; PEDRAM, A.; PARK, S. T.; LEVIN, E. R. Proximal events in signaling by plasma membrane estrogen receptors. J. Biol. Chem., v. 278, p. 2701-12, 2003 b.

RIBEIRO, R. C. J.; KUSHNER, P. J.; BAXTER, J. D. The Nuclear Hormone Receptor Gene Superfamily. Annu. Rev. Med., v. 46, p. 443-53, 1995.

RXLIST: THE INTERNET DRUG INDEX. Drugs A-Z. Available from: $<$ http://www.rxlist.com>. Acesso em: 07 Out. 2008.

SAFINA, A.; VANDETTE, E.; BAKIN, A. V. ALK5 promotes tumor angiogenesis by upregulating matrix metalloproteinase-9 in tumor cells. Oncogene, v. 26, p. 2407-22, 2006.

SAMBROOK, J.; FRITSCH, E. F.; MANIATIS, T. Molecular Cloning: A Laboratory Manual. $2^{\text {nd }}$ ed. New York: Cold Spring Harbor Laboratory Press, 1989. 3 v.

SAMPATH, D.; WINNEKER, R. C.; ZHANG, Z. Cyr61, a Member of the CCN Family, is Required for MCF-7 Cell Proliferation: Regulation by 17beta-estradiol and Overexpression in Human Breast Cancer. Endocrinology, v. 142, p. 2540-8, 2001.

SCHNEIDER, B. G.; RHA, S. Y.; CHUNG, H. C.; BRAVO, J. C.; MERA, R.; TORRES, J. C.; PLAISANCE, K. T., JR.; SCHLEGEL, R.; McBRIDE, C. M.; REVELES, X. T.; LEACH, R. J. Regions of Allelic Imbalance in the Distal Portion of Chromosome 12q in Gastric Cancer. Mol. Pathol., v. 56, p. 141-9, 2003.

SCHUCHARD, M.; LANDERS, J. P.; SANDHU, N. P.; SPELBERG, T.C. Steroid Hormone Regulation of Nuclear Proto-Oncogenes. Endocr. Rev., v. 14, p. 659-69, 1993.

SELLS, S. F.; WOOD, D. P.; JOSHI-BARVE, S. S.; MUTHUKUMAR, S.; JACOB, R. J.; CRIST, S. A.; HUMPHREYS, S.; RANGNEKAR, V. M. Commonality of the Gene Programs Induced by Effectors of Apoptosis in Androgen-Dependent and-Independent Prostate Cells. Cell. Growth Differ., v. 5, p. 457-66, 1994.

SEUNINGEN, I. V.; OSTROWSKI, J.; BUSTELO, X. R.; SLEATH, P. R.; BOMSZTYK, K. The K Protein Domain That Recruits the Interleukin 1-responsive K Protein Kinase Lies Adjacent to a Cluster of c-Src and Vav SH3-binding Sites. J. Biol. Chem., v. 270, p. 26976$85,1995$. 
SHAO, W.; BROWN, M. Advances in Estrogen Receptor Biology: Prospects for Improvements in Targeted Breast Cancer Therapy. Breast Cancer Res., v. 6, p. 39-52, 2004.

SHAW, J. A.; UDOKANG, K.; MOSQUERA, J-M.; CHAUHAN, H.; JONES, J. L.; WALKER, R. A. Oestrogen Receptors Alpha and Beta Differ in Normal Human Breast and Breast Carcinomas. J. Pathol., v. 198, p. 450-7, 2002.

SHEIKH, M. S.; GARCIA, M.; PUJOL, P.; FONTANA, J. A.; ROCHEFORT, H. Why Are Estrogen Receptor-Negative Breast Cancers More Aggressive than the Estrogen ReceptorPositive Breast Cancers? Invasion Metastasis, v. 14, p. 329-36, 1994.

SMOLNIKAR, K.; LÖFFEK, S.; SCHULZ, T.; MICHNA, H.; DIEL, P. Treatment with the pure antiestrogen faslodex (ICI 182780) induces tumor necrosis factor receptor 1 (TNFR1) expression in MCF-7 breast cancer cells. Breast Cancer Res. Treat., v. 63, p. 249-59, 2000.

SOMMER, S.; FUQUA, A. A. W. Estrogen Receptor and Breast Cancer. Semin. Cancer Biol., v. 11, p. 339-52, 2001.

SOULE, H. D.; VAZQUEZ, J.; LONG, A.; ALBERT, S.; BRENNAN, M. A Human Cell Line from a Pleural Effusion from a Breast Carcinoma. J. Natl. Cancer Inst., v.51, p. 1409$16,1973$.

STOICA, A.; SACEDA, M.; DORAISWAMY, V. L.; COLEMAN, C.; MARTIN, M. B. Regulation of strogen Receptor- $\alpha$ Gene Expression by epidermal Growth Factor. J. Endocrinol., v. 165, p. 371-8, 2000.

TAN, B. T. ; PARK, C. Y.; AILLES, L. E.; WEISSMAN, I. L. The cancer stem cell hypothesis: a work in progress. Lab. Invest., v. 86, p. 1203-7, 2006.

TAPLIN, M. E.; BUBLEY, G. J.; SHUSTER, T. D.; FRANTZ, M. E.; SPOONER, A. E.; OGATA, G. L.; KERR, H. N.; BALK, S. P. Mutation of the Androgen-Receptor Gene in Metastatic Androgen-Independent Prostate Cancer. N. Engl. J. Med., v. 332, p. 1393-8, 1995.

TOYOSHIMA, Y.; KARAS, M.; YAKAR, S.; DUPONT, J.; LEE HELMAN; LEROITH, D. TDAG51 mediates the effects of insulin-like growth factor I (IGF-I) on cell survival. J. Biol. Chem., v. 279, p. 25898-904, 2004.

TRANSILENT ${ }^{\text {TM }}$ SH Vector Mix. Product User Manual. Panomics, p. 1-19, July 23, 2005.

TRAVERS, M.; KNOWLER, J. T. Oestrogen-Induced Expression of Oncogenes in Immature Rat Uterus. F.E.B.S. Lett., v. 211, p. 27-30, 1987.

TRAVIS, R. C.; KEY, T. Oestrogen Exposure and Breast Cancer Risk. Breast Cancer Res., v. 5, p. 239-47, 2003.

TRICHOPOULOS, D.; ADAMI, H. O.; EKBOM, A.; HSIEH, C. C.; LAGIOU, P. Early life events and conditions and breast cancer risk: from epidemiology to etiology. Int. J. Cancer, v. 122, p.481-5, 2008. 
USER BULlETIN. ABI Prism 7700 Sequence Detection System. Appl. Biosyst., n. 2, p. 135, Dec. 1997.

VanAGTHOVEN T.; TIMMERMANS, M.; FOEKENS, J. A.; DORSSERS, L. C. J.; HENZEN-LOGMANS, S. C. Differential Expression of Estrogen, Progesterone, and Epidermal Growth Factor Receptors in Normal, Benign, and Malignant Human Breat Tissues Using Dual Staining Immunohistochemistry. Am. J. Pathol., v. 244, p. 1238-46, 1994.

VANDESOMPELE, J.; DE PRETER, K.; PATTYN, F.; POPPE, B.; VAN ROY, N.; DE PAEPE, A.; SPELEMAN, F. Accurate normalization of real-time quantitative RT-PCR data by geometric averaging of multiple internal control genes. Genome Biol. v. 3, p. RESEARCH0034.1-12, 2002.

VARGO-GOGOLA, T.; ROSEN, J. M. Modelling breast cancer: one size does not fit all. Nat. Rev. Cancer, v. 7, p. 659-72, 2007.

WEIHUA, Z.; ANDERSSON, S.; CHENG, G.; SIMPSON, E. R.; WARNER, M.; GUSTAFSSON, J-A. Update on Estrogen Signaling. F.E.B.S. Lett., v. 546, p. 17-24, 2003.

WELCSH, P. L.; KING, M. C. BRCA1 and BRCA2 and the Genetics of Breast and Ovarian Cancer. Hum. Mol. Genet., v. 10, p. 705-13, 2001.

WHITE, R.; PARKER, M. G. Molecular Mechanisms of Steroid Hormone Action. Endocr. Relat. Cancer, v. 5, p. 1-14, 1998.

WITTERS, I.; KUMAR, R.; CHINCHILLI, V.; LIPTON, A. Enhanced Antiproliferative Activity of the Combination of Tamoxifen Plus HER-2-neu Antibody. Breast Cancer Res Treat., v. 42, p. 1-5, 1997.

WONG, C-W.; McNALLY, C.; NICKBARG, E.; KOMM, B. S.; CHESKIS, B. J. Estrogen Receptor-Interacting Protein that Modulates its Nongenomic Activity-Crosstalk Src/Erk Phosphorylation Cascade. Proc. Natl. Acad. Sci. U.S.A, v. 99, p. 14783-8, 2002.

WU, Y.; KARAS, M.; DUPONT, J.; ZHAO, H.; TOYOSHIMA, Y.; LE ROITH, D. Multiple signaling pathways are involved in the regulation of IGF-I receptor inhibition of PTENenhanced apoptosis. Growth Horm. IGF Res., v. 14, p. 52-8, 2004.

YANG, J-P.; REDDY, T. R.; TRUONG, K. T.; SUHASINI, M.; WONG-STAAL, F. Functional Interaction of Sam68 and Heterogeneous Nuclear Ribonucleoprotein $\mathrm{K}$. Oncogene, v. 21, p. 7187-94, 2002.

YARDEN, R. I.; WILSON, M. A.; CHRYSOGELOS, S. A Estrogen suppression of EGFR Expression in Breast Cancer Cells: A Possible Mechanism to Modulate Growth. J. Cell. Biochem. Suppl., v. 36, p. 232-46, 2001.

YARDEN, Y.; SLIWKOWSKI, M. X. Untangling the ErbB signalling network. Nat. Rev. Mol. Cell. Biol., v. 2, p. 127-37, 2001. 
ZHOU, W.; MUGGERUD, A. A.; VU, P.; DUE, E. U.; SØRLIE, T.; BØRRESEN-DALE, AL.; WÄRNBERG, F.; LANGERØD, S. Full sequencing of TP53 identifies identical mutations within in situ and invasive components in breast cancer suggesting clonal evolution. Mol. Oncol., v. 3, p. 214-19, 2009. 